Nevada

Environmental

Restoration

Project

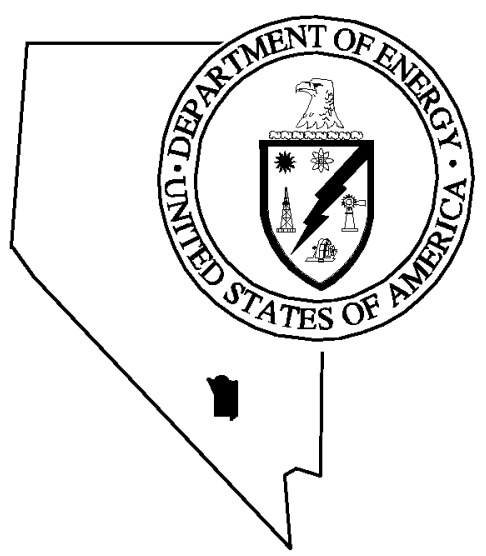

Corrective Action Investigation Plan for Corrective Action Unit No. 423: Building 03-60

Underground Discharge Point,

Tonopah Test Range, Nevada

Controlled Copy No.:

Revision No: 0

October 1997

Environmental Restoration

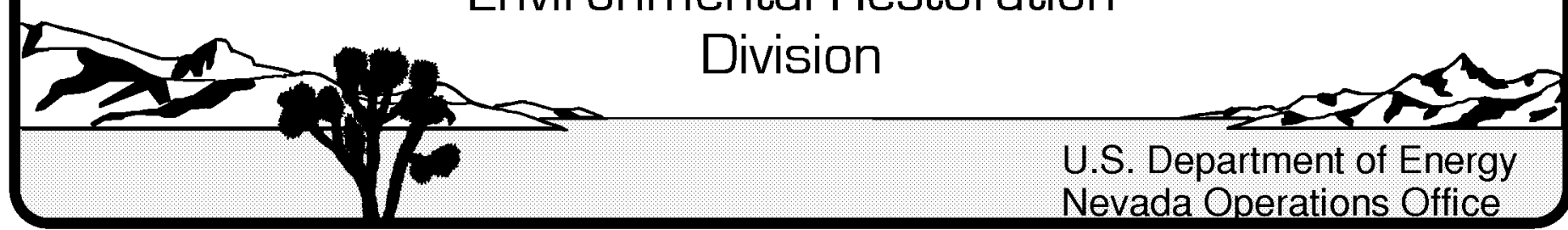




\title{
CORRECTIVE ACTION INVESTIGATION PLAN FOR CORRECTIVE ACTION UNIT NO. 423: BUILDING 03-60 UNDERGROUND DISCHARGE POINT, TONOPAH TEST RANGE, NEVADA
}

\author{
DOE Nevada Operations Office \\ Las Vegas, Nevada
}

Controlled Copy No.:

Revision No.: 0

October 1997 
This report has been reproduced directly from the best available copy.

Available to DOE and DOE contractors from the Office of Scientific and Technical Information, P.O. Box 62,

Oak Ridge, TN 37831; prices available from (423) 576-8401.

Available to the public from the National Technical Information Service, U.S. Department of Commerce, 5285 Port Royal

Road, Springfield, VA, 22161, telephone (703) 487-4650. 


\section{CORRECTIVE ACTION INVESTIGATION PLAN FOR CORRECTIVE ACTION UNIT NO. 423: \\ BUILDING 03-60 UNDERGROUND DISCHARGE POINT, TONOPAH TEST RANGE, NEVADA}

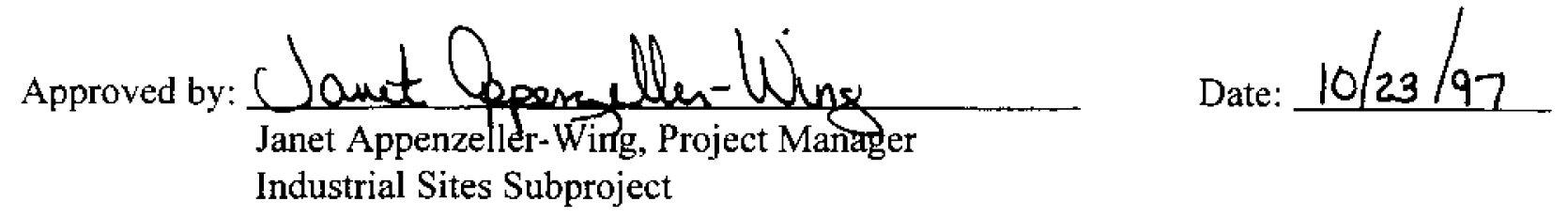

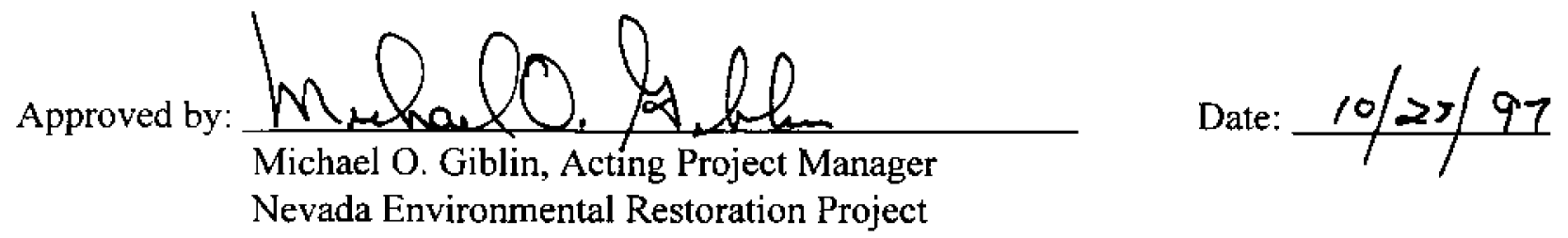




\section{Table of Contents}

List of Figures $\ldots \ldots \ldots \ldots \ldots \ldots \ldots \ldots \ldots \ldots \ldots \ldots \ldots \ldots \ldots \ldots$ iii

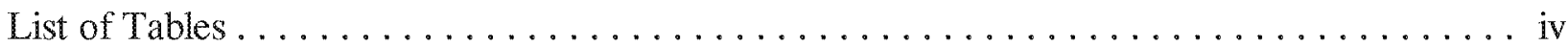

List of Acronyms and Abbreviations $\ldots \ldots \ldots \ldots \ldots \ldots \ldots \ldots \ldots \ldots \ldots \ldots$

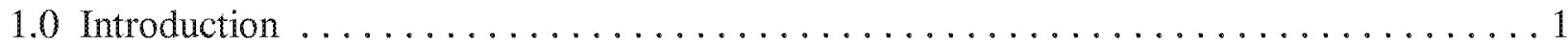

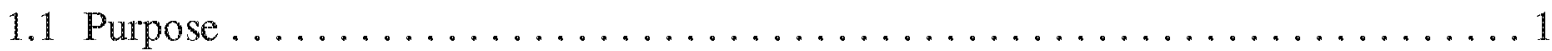

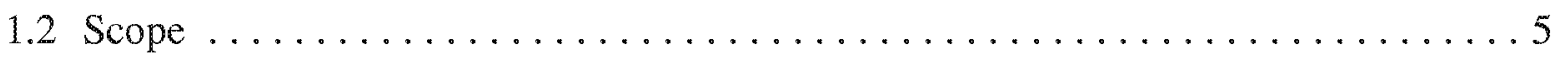

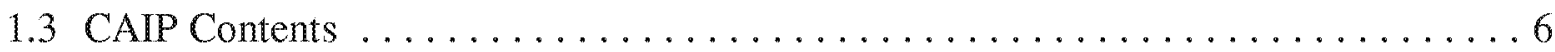

2.0 Facility Description $\ldots \ldots \ldots \ldots \ldots \ldots \ldots \ldots \ldots \ldots \ldots \ldots \ldots \ldots$

2.1 Physical Setting $\ldots \ldots \ldots \ldots \ldots \ldots \ldots \ldots \ldots \ldots \ldots \ldots \ldots \ldots \ldots$

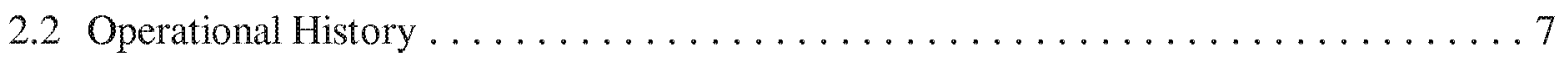

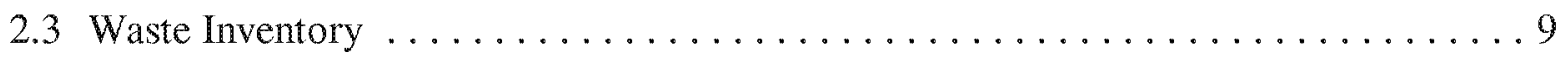

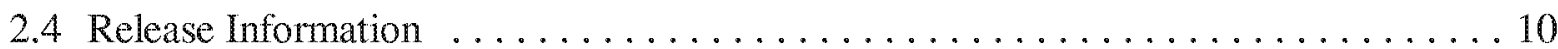

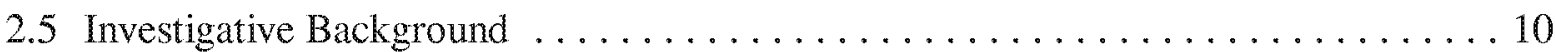

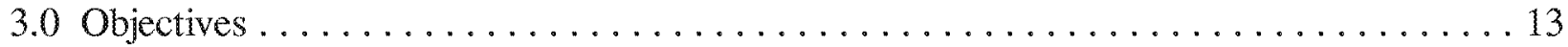

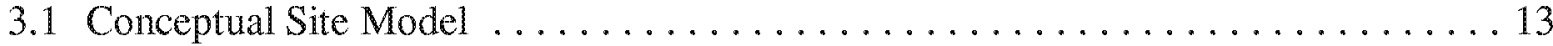

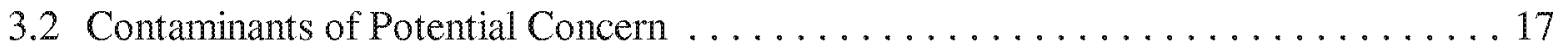

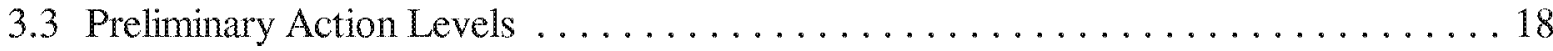

3.4 DQO Process Discussion . . . . . . . . . . . . . . . . . . . . . . . . . 19

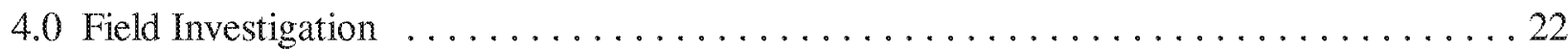

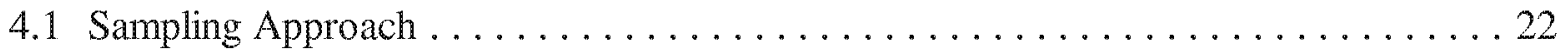

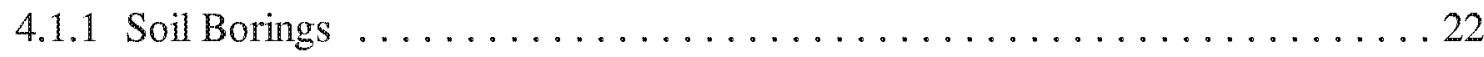

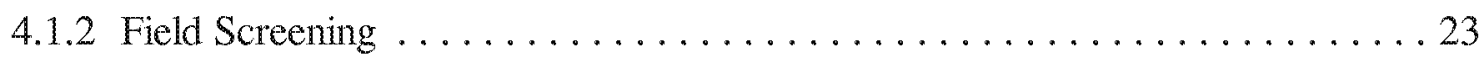

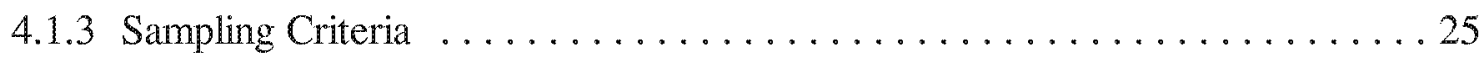

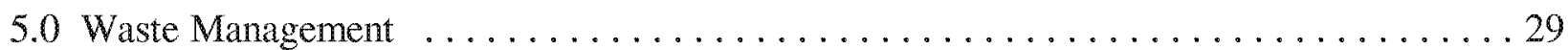

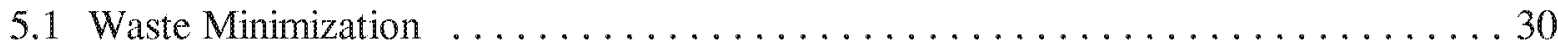

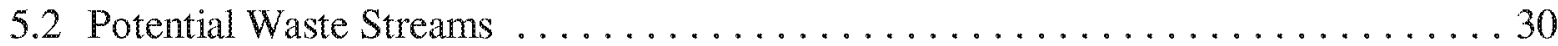


5.3 Investigation-Derived Waste Management . . . . . . . . . . . . . . 30

5.3 .1 Sanitary Waste Management . . . . . . . . . . . . . . . . 31

5.3 .2 Low-Level Waste Management . . . . . . . . . . . . . . . . . 31

5.3 .3 Hazardous Waste Management ........................ 31

5.3 .4 Hydrocarbon Waste Management . . . . . . . . . . . . . . . . 33

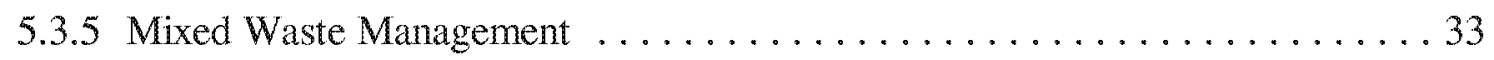

6.0 Duration and Records Availability . . . . . . . . . . . . . . 34

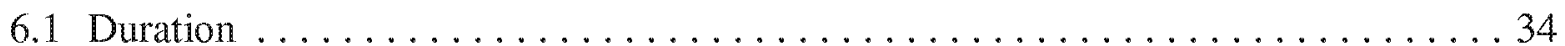

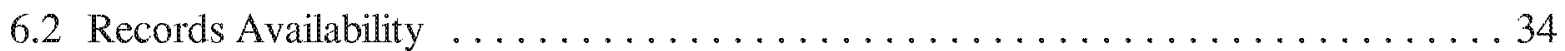

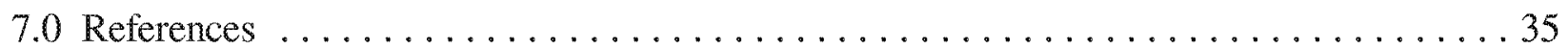

Appendix A - Data Quality Objectives Worksheet .................... A-1

Attachment 1 - Building 03-60 Site Map and Aerial Photograph . . . . . . . . . . . A-19

Attachment 2 - Building 03-60 UDP Photographs ................. A-22

Attachment 3 - Building 03-60 UDP Waste Oil Sampling Results . . . . . . . . . . A-25

Attachment 4 - CAU No. 423 Waste Determination . . . . . . . . . . . . . . A-28

Attachment 5 - Uniform Hazardous Waste Manifests . . . . . . . . . . . . . . A-36

Appendix B - Nevada Department of Environmental Protection Document Review

Sheet for Draft CAIP $\ldots \ldots \ldots \ldots \ldots \ldots \ldots \ldots \ldots \ldots \ldots \ldots \ldots \ldots \ldots \ldots$ 


\section{List of Figures}

Number

Title

Page

1-1 Tonopah Test Range Location Map $\ldots \ldots \ldots \ldots \ldots \ldots \ldots \ldots \ldots \ldots$

1-2 Area 3 Location Map, Tonopah Test Range .................... . 3

1-3 Building 03-60 UDP Location Map . . . . . . . . . . . . . . . . 4

2-1 Conceptual Cross-Section of the Building 03-60 UDP $\ldots \ldots \ldots \ldots \ldots \ldots \ldots$

3-1 Exposure Pathway Conceptual Model . . . . . . . . . . . . . . . . 15

3-2 Subsurface Release Conceptual Model $\ldots \ldots \ldots \ldots \ldots \ldots \ldots \ldots \ldots \ldots$

4-1 Proposed Borehole Locations, Building 03-60 UDP . . . . . . . . . . . 24

4-2 Schematic of the Core-Barrel Sampler ...................... 27 
Page iv of vi

\section{List of Tables}

Number

Title

Page

3-1 Site Characterization Laboratory Analytical Requirements . . . . . . . . . . . 20

4-1 Geotechnical Analyses, Building 03-60 UDP . . . . . . . . . . . . . . 26

5-1 Action Levels for IDW Contaminants $\ldots \ldots \ldots \ldots \ldots \ldots \ldots \ldots \ldots \ldots \ldots \ldots$ 


\section{List of Acronyms and Abbreviations}

$\begin{array}{ll}\text { ARAR } & \text { Applicable or relevant and appropriate requirement(s) } \\ \text { ASTM } & \text { American Society for Testing and Materials } \\ \text { bgs } & \text { Below ground surface } \\ \text { CADD } & \text { Corrective Action Decision Document } \\ \text { CAIP } & \text { Corrective Action Investigation Plan } \\ \text { CAP } & \text { Corrective Action Plan } \\ \text { CAS } & \text { Corrective Action Site(s) } \\ \text { CAU } & \text { Corrective Action Unit(s) } \\ \text { CFR } & \text { Code of Federal Regulations } \\ \text { cm } & \text { Centimeter(s) } \\ \text { COC } & \text { Constituent(s) of concern } \\ \text { DOE } & \text { U.S. Department of Energy } \\ \text { DOE/NV } & \text { U.S. Department of Energy, Nevada Operations Office } \\ \text { DOT } & \text { U.S. Department of Transportation } \\ \text { DQO } & \text { Data Quality Objective(s) } \\ \text { EM } & \text { Engineering Manual } \\ \text { EPA } & \text { U.S. Environmental Protection Agency } \\ \text { EQL } & \text { Estimated Quantitation Limit } \\ \text { ERD } & \text { Environmental Restoration Division } \\ \text { ERP } & \text { Environmental Restoration Project } \\ \text { FFACO } & \text { Federal Facility Agreement and Consent Order } \\ \mathrm{ft} & \text { Foot (feet) } \\ \text { gal } & \text { Gallon(s) } \\ \text { HASP } & \text { Health and Safety Plan } \\ \text { IDW } & \text { Investigation-derived waste } \\ \text { in. } & \text { Inch(es) } \\ \text { IT } & \text { IT Corporation } \\ \text { km } & \text { Kilometer(s) } \\ \text { L } & \text { Liter(s) } \\ \mathrm{m} & \text { Meter(s) } \\ \text { mg/kg } & \text { Milligram(s) per kilogram } \\ \text { mg/L } & \text { Milligram(s) per liter } \\ \text { mi } & \text { Mile(s) } \\ & \end{array}$




\section{List of Acronyms and Abbreviations (Continued)}

$\begin{array}{ll}\text { NAC } & \text { Nevada Administrative Code } \\ \text { NAFR } & \text { Nellis Air Force Range } \\ \text { NDEP } & \text { Nevada Division of Environmental Protection } \\ \text { NTS } & \text { Nevada Test Site } \\ \text { NTSWAC } & \text { Nevada Test Site Waste Acceptance Criteria } \\ \text { ORERP } & \text { Off-Site Radiation Exposure Review Project } \\ \text { PCB } & \text { Polychlorinated biphenyl(s) } \\ \text { PPE } & \text { Personal protective equipment } \\ \text { ppm } & \text { Part(s) per million } \\ \text { QA/QC } & \text { Quality assurance and quality control } \\ \text { QAPP } & \text { Quality Assurance Project Plan } \\ \text { RCRA } & \text { Resource Conservation and Recovery Act } \\ \text { RPD } & \text { Relative percent difference } \\ \text { SSHASP } & \text { Site-Specific Health and Safety Plan } \\ \text { SVOC } & \text { Semivolatile organic compound(s) } \\ \text { TC } & \text { Toxicity characteristic } \\ \text { TCLP } & \text { Toxicity Characteristic Leaching Procedure } \\ \text { TPH } & \text { Total petroleum hydrocarbon(s) } \\ \text { TTR } & \text { Tonopah Test Range } \\ \text { UDP } & \text { Underground Discharge Point } \\ \text { USACE } & \text { United States Army Corps of Engineers } \\ \text { UST } & \text { Underground Storage Tank } \\ \text { VOC } & \text { Volatile organic compound(s) } \\ \mu \mathrm{g} / L & \text { Microgram(s) per liter } \\ \text { \%R } & \text { Percent recovery } \\ & \end{array}$




\subsection{Introduction}

This Corrective Action Investigation Plan (CAIP) has been developed in accordance with the Federal Facility Agreement and Consent Order (FFACO) that was agreed to by the U.S. Department of Energy, Nevada Operations Office (DOE/NV), the State of Nevada Division of Environmental Protection (NDEP), and the U.S. Department of Defense. The CAIP is a document that provides or references all of the specific information for investigation activities associated with Corrective Action Units (CAUs) or Corrective Action Sites (CASs) (FFACO, 1996). As per the FFACO (1996), CASs are sites potentially requiring corrective action(s) and may include solid waste management units or individual disposal or release sites. Corrective Action Units consist of one or more CASs grouped together based on geography, technical similarity, or agency responsibility for the purpose of determining corrective actions.

This CAIP contains the environmental sample collection objectives and the criteria for conducting site investigation activities at CAU No. 423, the Building 03-60 Underground Discharge Point (UDP), which is located in Area 3 at the Tonopah Test Range (TTR). The TTR, part of the Nellis Air Force Range, is approximately 225 kilometers (km) (140 miles [mi]) northwest of Las Vegas, Nevada (Figures 1-1 and 1-2). Corrective Action Unit No. 423 is comprised of only one CAS (No. 03-02-002-0308), which includes the Building 03-60 UDP and an associated discharge line extending from Building 03-60 to a point approximately 73 meters $(\mathrm{m})$ (240 feet [ft]) northwest as shown on Figure 1-3.

\subsection{Purpose}

The UDP is a vertical, 107-centimeter (cm) (42-inch [in.]) corrugated steel culvert approximately $73 \mathrm{~m}$ (240 ft) northwest of Building 03-60. The UDP was used between approximately 1965 and 1990 to dispose of waste fluids from the Building 03-60 automotive maintenance shop. It is likely that soils surrounding the UDP have been impacted by oil, grease, cleaning supplies and solvents (IT, 1994) as well as waste motor oil and other automotive fluids released from the UDP.

The purpose of the investigation at the Building 03-60 UDP is to:

- Determine the UDP configuration. 


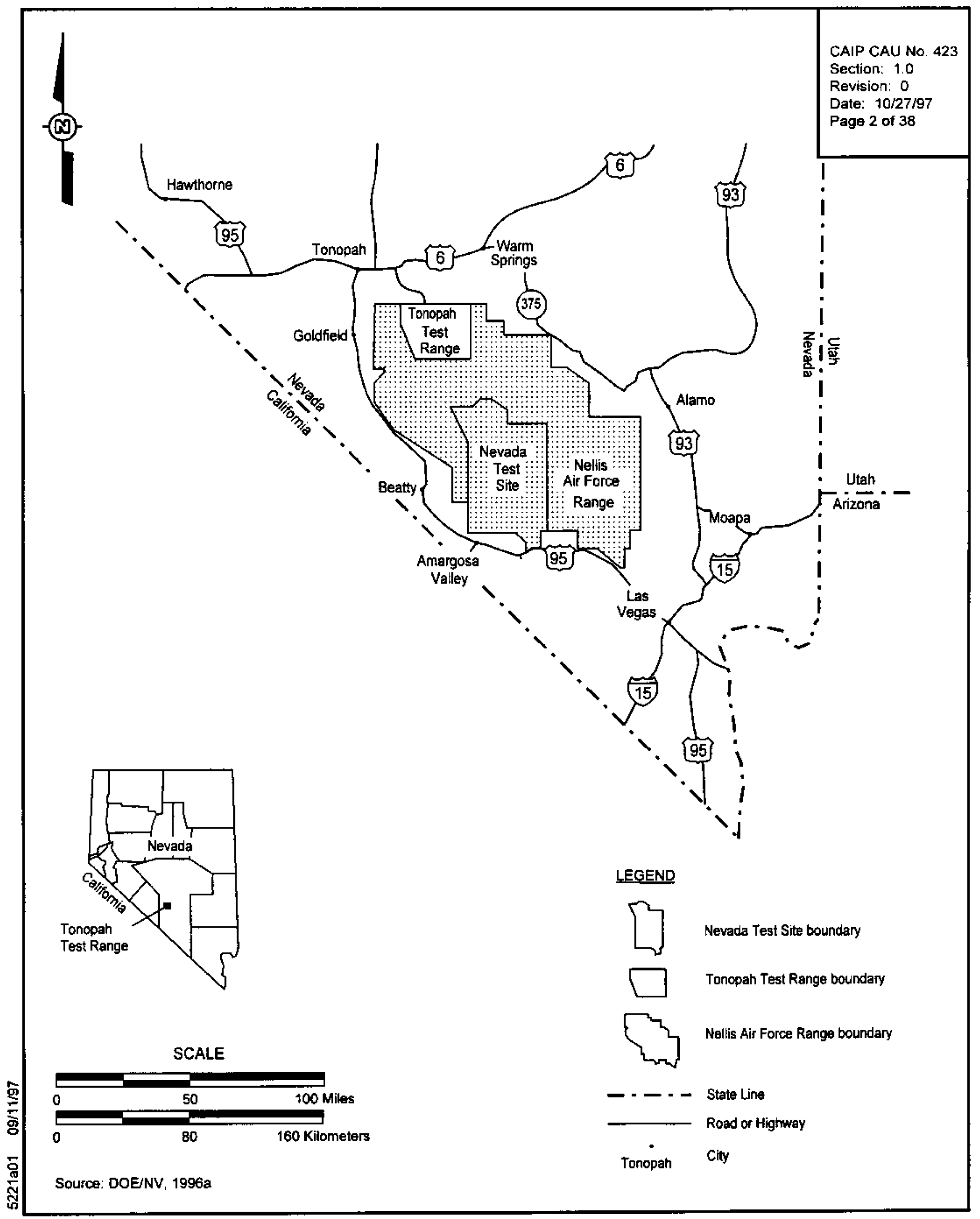

Figure 1-1

Tonopah Test Range Location Map 


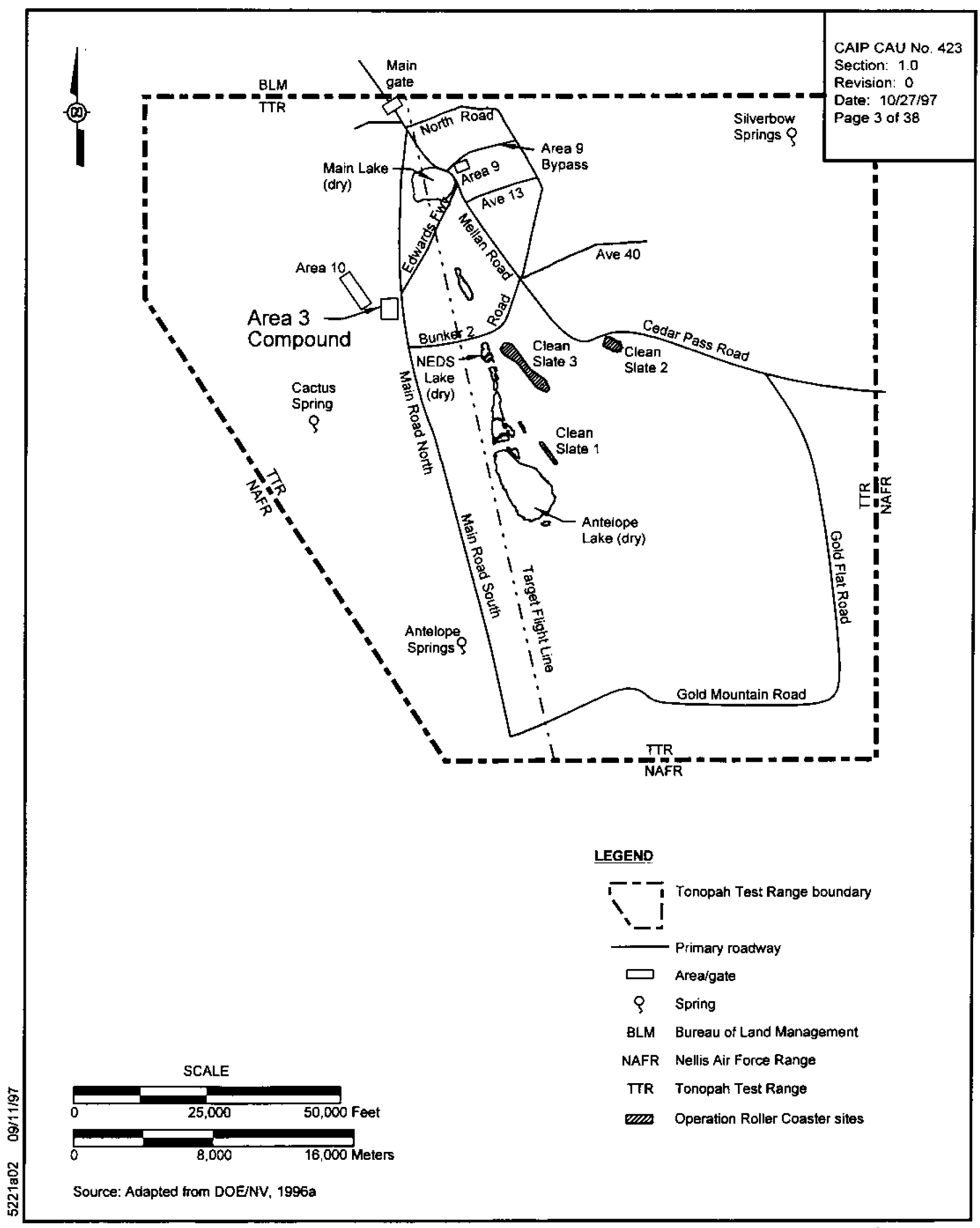

Figure 1-2

Area 3 Location Map, Tonopah Test Range 


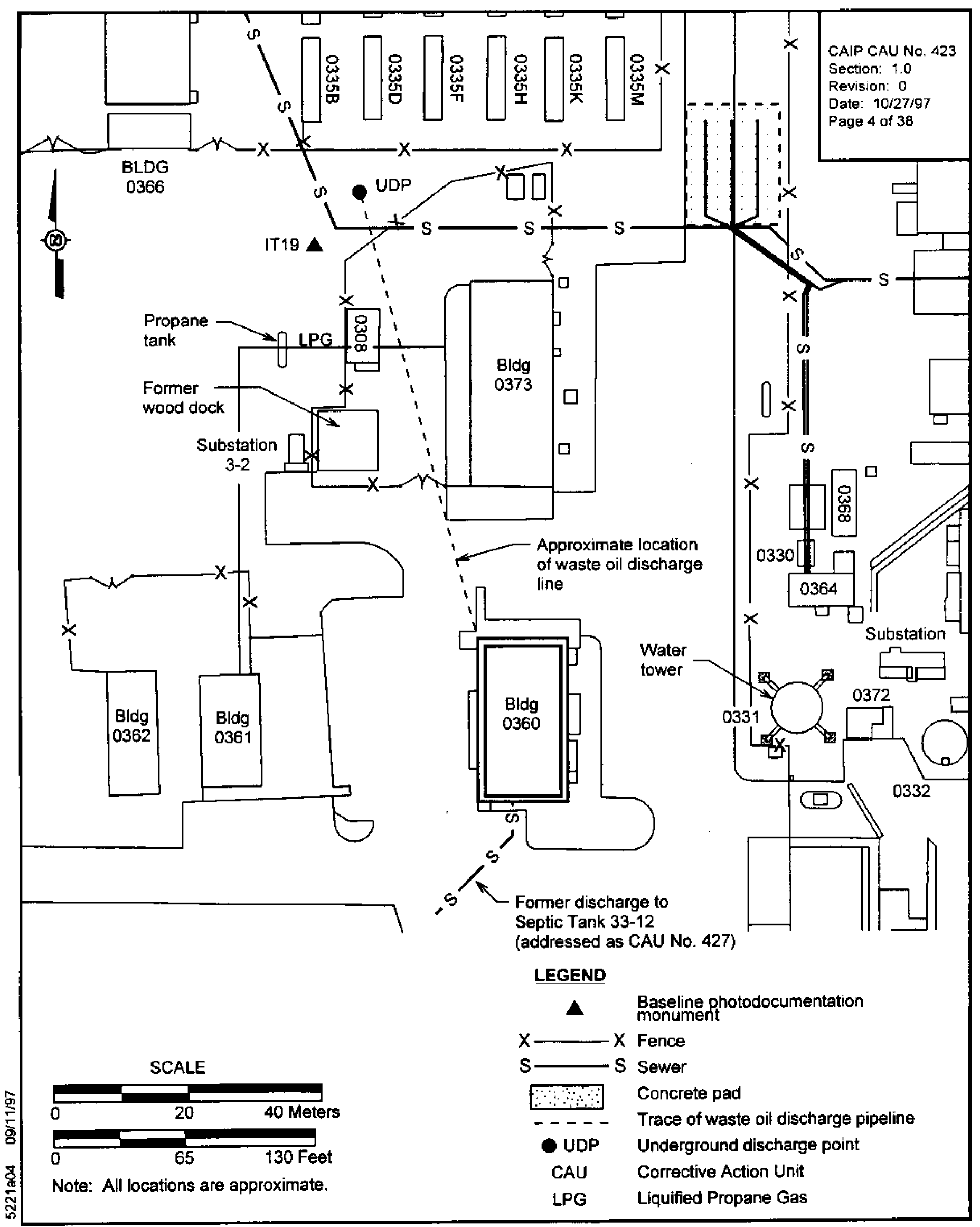

Figure 1-3

Building 03-60 UDP Location Map 
- Identify the presence and nature of possible contaminants of potential concern (COCs) within the UDP.

- Determine the vertical and lateral extent of possible contaminant migration.

- Evaluate the potential impact to human health and the environment.

- Provide sufficient information and data to develop and evaluate appropriate corrective actions for the CAS.

This CAIP was developed using the U.S. Environmental Protection Agency (EPA) Data Quality Objectives (DQOs) (EPA, 1994) process to clearly define the purpose(s) for which environmental data will be used and to design a data collection program that will satisfy these goals. A DQO scoping meeting was held prior to preparation of this plan; a summary of the meeting notes is presented in Subsection 3.4 and in an unedited worksheet format as Appendix A.

\subsection{Scope}

The scope of this investigation includes the following:

- Drilling characterization boreholes using the dry sonic drilling method or another comparable method capable of penetrating potential leach rock materials (e.g., concrete or gravel) and providing suitable core for sample collection and logging of subsurface conditions

- Evaluating the UDP construction and configuration

- Conducting continuous field screening to direct drilling and sampling activities and provide an initial assessment of subsurface impact

- Collecting soil samples for laboratory analysis of environmental and geotechnical parameters

- Logging core to assess soil characteristics

The drilling locations will be selected to target the UDP itself and the area immediately surrounding the UDP which is most likely to be impacted by contaminant migration.

\subsection{CAIP Contents}

Section 1.0 of this CAIP provides an introduction to this project, including the purpose and scope for this corrective action investigation. The FFACO (1996) requires that CAIPs address the following elements: 
- Management

- Technical aspects

- Quality assurance

- Health and safety

- Public involvement

- Field sampling

- Waste management

The managerial aspects of this project are discussed in the DOE/NV Environmental Restoration Project (ERP) Project Management Plan, Rev. 0 (DOE/NV, 1994a) and the site-specific Project Management Plan. The technical aspects of this CAIP are contained in the Corrective Action Unit Work Plan, Tonopah Test Range, Nevada (hereafter referred to as the TTR Work Plan) (DOE/NV, 1996a) and in Sections 3.0 and 4.0 of this document. General field and laboratory quality assurance and quality control (QA/QC) issues are presented in the Industrial Sites Quality Assurance Project Plan (QAPP) (DOE/NV, 1996b), and the specific aspects of field QA/QC are discussed in approved procedures. Collection of field QC samples will be specified in site-specific field instructions which will be written prior to commencement of field activities. The health and safety aspects of this project are documented in the Environmental Restoration Project Health and Safety Plan (HASP) (DOE/NV, 1996c) and will also be supplemented with a site-specific HASP written prior to commencement of field work. No CAU-specific public involvement activities are planned at this time; however, an overview of public involvement is documented in the "Public Involvement Plan" in Appendix V of the FFACO (1996). Field sampling activities are discussed in Section 4.0 of this CAIP. Waste management issues are discussed in the TTR Work Plan (DOE/NV, 1996a) and in Section 5.0 of this CAIP. The project schedule and records availability information are discussed in Section 6.0 of this CAIP, and a list of project references is provided in Section 7.0 of this CAIP. 


\subsection{Facility Description}

Corrective Action Unit No. 423 is comprised of the Building 03-60 UDP and an associated waste oil discharge line. Process knowledge and available resources relating to the Building 03-60 and UDP site history were examined during the DQO process (Appendix A). This information includes TTR data reports describing previous field efforts and sampling results, geophysical survey data, historical aerial photographs, and site maps. General background information pertaining to the history of TTR and the Area 3 Compound, a geologic assessment, and an overview of the area hydrogeology including depths to groundwater are provided in the TTR Work Plan (DOE/NV, 1996a). A summary of the information specific to Building 03-60 and the UDP is presented in the following sections.

\subsection{Physical Setting}

Surface materials around the site consist of sand, gravel, and cobbles with little to no vegetation. The topography slopes gently to the northwest with surface drainage flowing in the same direction. Depth to groundwater beneath the UDP is estimated at 110 to $120 \mathrm{~m}$ (361 to $394 \mathrm{ft}$ ) below ground surface (bgs). The groundwater flow direction is generally to the north-northwest (DOE/NV, 1996a).

The specific configuration of the UDP is unknown; however, a gravel layer or some type of irregular base is believed to exist at the bottom of the UDP. Based on historical knowledge of typical UDP construction techniques, a gravel or leach rock (e.g., concrete "rip rap") column of unknown vertical extent may exist below the bottom of the UDP. If the UDP base is poured concrete, it may indicate the UDP is part of a concrete holding tank below the UDP base; however, this is unlikely. The most likely UDP configuration is that of a leach rock infiltration column of unknown depth below the bottom of the culvert. A conceptual cross-sectional view of the Building 03-60 UDP is shown in Figure 2-1.

\subsection{Operational History}

Building 03-60, the Auto Maintenance Shop in the TTR Area 3 compound (Figures 1-2 and 1-3), was constructed in 1962 as a light-duty fleet maintenance shop and is currently in use for the same purpose. Originally, waste oils were drained from Building 03-60 to Septic Tank 33-12 and the associated leachfield (Figure 1-3) to the south of Building 03-60. After the septic tank 


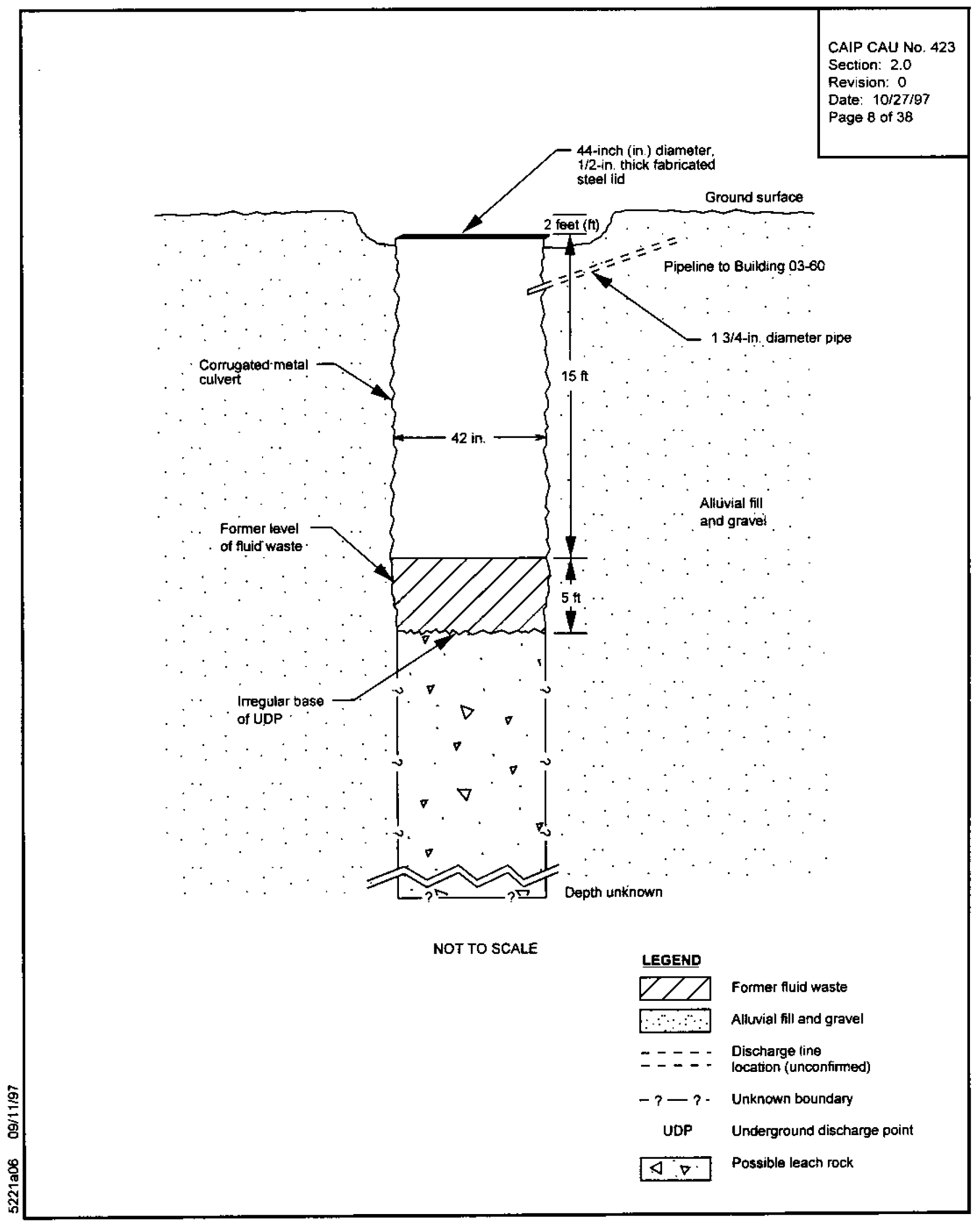

Figure 2-1

Conceptual Cross-Section of the Building 03-60 UDP 
was abandoned (possibly in 1965), the waste oil products (including anti-freeze, motor oil, and hydraulic oil) were instead discharged into a sump believed to be located at the northwest corner of Building 03-60 (DOE/NV, 1996a). A gravity-fed discharge line from the sump carried the waste oil to a point approximately $73 \mathrm{~m}(240 \mathrm{ft})$ to the northwest, where the line fed into what was originally thought to be an underground storage tank (UST) based on interviews and at least one site drawing. It should be noted that Septic Tank 33-12 and its associated leachfield are not included as part of the CAU No. 423 investigation, but are being addressed under CAU No. 427, the Area 3 Septic Waste Systems Numbers 2 and 6.

The specific time period of waste oil discharge to the Building 03-60 sump is unknown, but may have been from 1965 to 1989 or 1990. Sometime prior to 1993, wastes generated at the Auto Maintenance Shop were no longer drained into the UST (UDP); instead, they were containerized and delivered to the United States Air Force for disposal (DOE/NV, 1996a). It is known that a minimum of approximately 1,514 liters (L) (400 gallons [gal]) of waste oil were drained into the UST (UDP) over an indeterminate period of time (see Section 2.3); the actual amount may be significantly greater.

\subsection{Waste Inventory}

Historical records of product use and disposal at the Building 03-60 Automotive Maintenance Shop have not been located and/or were not maintained. However, based on process knowledge of typical automotive maintenance activities, products likely to have been discharged to the Building 03-60 UDP include oil, grease, cleaning supplies, and solvents (IT, 1994) as well as waste motor oil and other automotive fluids.

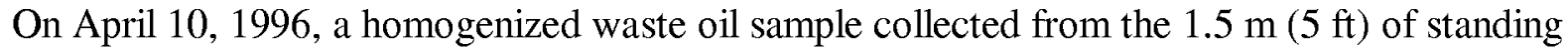
liquid in the UDP was submitted for laboratory analysis of volatile organic compounds (VOCs), semivolatile organic compounds (SVOCs), Resource Conservation and Recovery Act (RCRA) Toxicity Characteristic (TC) metals, total pesticides, total polychlorinated biphenyls (PCBs), flashpoint, and radionuclides. Detected analytes included volatile organic compounds, aromatics, and chlorinated aromatics. A table listing the analytical results for the detected parameters is provided as Attachment 3 of Appendix A.

Based on these sampling results, an extensive research effort was conducted in 1996 as part of the waste determination (see Attachment 4 of Appendix A). Shop surveys conducted by Reynolds Electrical and Engineering Co., Inc., Industrial Hygiene personnel were located and included in the waste determination package (IT, 1996c). Material Safety Data Sheets were obtained for 
products identified in the shop surveys to aid in the waste determination (IT, 1996c). A solvent known as "Safety Kleen" (i.e., <10\% orthodichlorobenzene by volume) was found to have been used in the building. Although there are no records indicating this solvent was disposed in the UDP, a trace amount of orthodichlorobenzene was detected in the liquid analyzed from the UDP. As a result, the waste determination indicated the UDP liquid contained an "F002" listed waste in the form of orthodichlorobenzene (1,2-dichlorobenzene) (IT, 1996c). It is unknown whether the standing liquid composition represented all waste oil products previously disposed since the UDP inception or only those products from a certain disposal time period.

\subsection{Release Information}

Approximately 1,514 L (400 gal) of liquid waste was removed from the UDP and properly disposed of in September, 1966 (IT, 1996a). Approximately $950 \mathrm{~L}$ (250 gal) of liquid waste is scheduled to be removed from the UDP and properly disposed of in October, 1997. It is unknown whether waste oil releases have occurred, but based on the suspected length of operation of the UDP system (up to 25 years), it is likely that the soils beneath and/or surrounding the UDP culvert have been impacted. It is also unknown whether groundwater has been impacted by a release. However, given the depth to groundwater, the viscous nature of the waste oil removed from the UDP, and the fine-grained native soils, a groundwater impact is unlikely.

\subsection{Investigative Background}

In July 1993, a ground-penetrating radar geophysical survey was performed to confirm the UST (UDP) location (IT, 1997a). Based on the survey results, a clear anomaly caused by the waste oil UST (UDP) was delineated. In addition, the waste oil line was traced with an electromagnetic line tracer from the UST (UDP) to Building 03-60. No apparent connections to the waste oil line from other sources (i.e., other buildings) were noted during this survey.

During a March 1994 inspection of Building 03-60, the sump could not be located and was suspected to be sealed beneath a more recently emplaced concrete flooring slab (DOE/NV, 1996a). The upgradient end of the discharge line was also not found. Although Building 03-60 is still active, it is assumed that the discharge line and sump are inactive and that no contributions are being made to the UDP from any source.

On March 20, 1996, a soil excavation effort was held to locate the supposed buried waste oil tank (IT, 1996a). During this excavation, it was determined that the subsurface structure was actually an underground discharge point rather than an underground storage tank. The UDP, consisting of a 107-centimeter (cm) (42-inch [in.]) diameter corrugated metal culvert, set vertically in the 
ground, was identified at a depth of $0.6 \mathrm{~m}$ (2 ft) below surface grade (IT, 1996b). The configuration of the culvert was consistent in size and location with the anomaly noted during ground penetrating radar surveys conducted in 1994 (IT, 1997a). Overall, the culvert was observed to be in good condition. However, several small holes were noted near the top. Two of the holes, located on opposite sides of the pipe, may have been used for holding a lowering bar in place. Additional small holes, likely due to corrosion, were also noted near the top.

The culvert opening was covered by a $112-\mathrm{cm}(44-\mathrm{in}$.$) diameter, 1.3-\mathrm{cm}(0.5-\mathrm{in}$.$) thick, fabricated$ steel lid. Approximately $30.5 \mathrm{~cm}$ (12 in.) below the rim was a 4.4-cm (1.75-in.) diameter galvanized pipe that is believed to be the downgradient end of the discharge line from Building

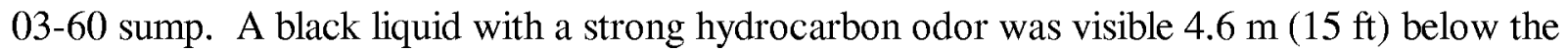
culvert rim. The liquid was determined to be approximately $1.5 \mathrm{~m}(5 \mathrm{ft})$ deep. No rings, indicative of higher fluid levels, were noted (IT, 1996b). It is unknown whether releases from the UDP into the surrounding subsurface have occurred. Building 03-60, the UDP, and the suspected location of the waste oil line are indicated on the site map (SNL, 1989) and aerial photograph (EG\&G, 1988) contained in Attachment 1 of Appendix A. Ground-level photographs of the UDP taken during the excavation activities (IT, 1996a) are shown in Attachment 2 of Appendix A.

Following collection and analysis of a waste oil sample in April, 1996 (IT, 1996a), the liquid in the UDP was removed (approximately 1,514 L [400 gal]), characterized, and properly disposed of in September 1996 (see Attachments 3, 4, and 5 of Appendix A). After pumping, a small amount of residual sludge remained at the bottom of the UDP culvert.

In June 1997, the fluid in the UDP was measured at approximately $21.6 \mathrm{~cm}(8.5 \mathrm{in}$.$) in depth$ (IT, 1997b). The fluid depth has increased to approximately $1 \mathrm{~m}(3.3 \mathrm{ft})$, and a second pumping is scheduled for October 1997. The additional liquid in the UDP is probably the product of three input sources: surface water, minor residual waste oil, and infiltration from surrounding soil. Surface water inflow is the most likely explanation for most of the fluid level increase since liquid was removed from the UDP in September 1996.

It is unlikely that liquid has been added to the UDP through the pipeline from Building 03-60 after the September 1996 pumping event. Wastes generated at the Auto Maintenance Shop are containerized and delivered to the United States Air Force for disposal (see Section 2.2) and there is no known connection between Building 03-60 and the UDP. A pipeline camera survey was conducted to examine the condition of the discharge pipe from Building 03-60 in early September 1997. The survey was conducted from the UDP end of the pipe, and revealed the pipe is 
damaged approximately $3.7 \mathrm{~m}(12 \mathrm{ft})$ from the UDP. The damage to the pipe prevents further investigation using a pipeline camera. Any possibility of additional input of fluid to the UDP through the pipe from Building 03-60 has been eliminated by sealing the pipe with a cap and Teflon tape in early October, 1997.

Recent field observations identified rain-storm produced surface water as a possible contributor to liquid in the UDP. The UDP lid was below grade in a small depression produced by exposing the UDP in March 1996. This depression was below grade at the base of a slope. Ponding of storm runoff in the depression was observed in September 1997 while it was lined with plastic. A field effort in early October 1997 sealed the UDP from further surface water input by extending the top of the UDP above the existing grade with an extension of metal culvert.

The remaining fluid input possibility is infiltration of liquid from the soil surrounding the UDP. This scenario is unlikely, but a depth-recording device was installed within the UDP to monitor any fluctuations of liquid depth. No fluctuations had been detected prior to the scheduled liquid removal in October 1997. The depth recorder will detect and record any increase in liquid level after the pumping event. 


\subsection{Objectives}

The sampling objectives were determined using the DQO process outlined by the EPA in their Guidance for the Data Quality Objectives Process (EPA, 1994). The DQOs are qualitative and quantitative statements that specify the quality of the data required to support potential courses of action for the UDP. The DQOs were developed to clearly define the purpose(s) for which environmental data will be used and to guide the design of a data collection program that will satisfy these goals. One tool used in the DQO process is the formulation of site conceptual models.

\subsection{Conceptual Site Model}

A conceptual model has been developed to postulate a subsurface release scenario and exposure pathways from the potential contaminant sources associated with the UDP. The model encompasses information on the geology, climate, hydrogeology and infrastructure at the TTR Area 3. Topography information is not considered in the model because of the limited areal extent of the CAU. Floodplain studies are not necessary for the model because the CAU is not located within a floodplain. The model is based on assumptions and premises that were discussed during the DQO process and outlined in the DQO worksheet (Appendix A). If the conceptual model is proven incorrect by the results of environmental sampling, then NDEP will be notified and the site rescoped. The following points summarize the primary assumptions that were included in the DQOs (Appendix A) and considered in formulating the site conceptual model:

- The UDP is assumed to have received waste only from Building 03-60 via the discharge line.

- Dates of discharge to UDP are unknown, but are assumed to be approximately 1965 to 1990.

- $\quad$ No discharge to the UDP has occurred since approximately 1990.

- Native soils in the UDP area are comprised of heterogeneous layers of clays, sands, and gravels (alluvium) with possible cobbles or boulders. Bedrock is not anticipated to be encountered in the UDP area.

- Depth to groundwater is between 110 and $120 \mathrm{~m}$ (361 to $394 \mathrm{ft}$ ) below ground surface (bgs).

- The total volume of waste liquid discharged to the UDP is unknown, but is greater than 400 gal. 
- The actual UDP configuration is unknown, but is assumed to contain gravel or leach rock to an unknown depth below the bottom of the corrugated metal culvert.

- Sampling results of liquid in the UDP indicate the presence of orthodichlorobenzene.

- Sampling results obtained during the 1996 sampling effort (see Attachment 3 of Appendix A) are assumed to be representative of COCs in UDP area.

- The impact to soil from COCs is assumed to be less than $15.2 \mathrm{~m} \mathrm{(50} \mathrm{ft)} \mathrm{bgs} \mathrm{and} \mathrm{less} \mathrm{than} \mathrm{a}$ 7.6-m (25-ft) lateral radius from the UDP center.

- If leach rock is present, the most significant component of COC migration would be in the downward direction with the area most likely impacted being the leach rock column below the UDP and the soils adjacent to the leach rock.

- If leach rock is not present, lateral migration may be initially more significant than vertical migration.

- Groundwater impact is unlikely because depth to groundwater is extensive (greater than $91.4 \mathrm{~m}$ [300 ft] [DOE/NV, 1996a]); the waste oil has a high viscosity which may preclude extensive migration; and the environmental conditions at the site (i.e., arid climate, low permeabilities) are not conducive to downward migration.

- Future use of Building 03-60 is anticipated to be similar to current use (actively used for light-duty automotive maintenance).

- Inadvertent excavation of contaminated material by site workers is the likely potential exposure pathway.

- The dry sonic drilling method (or an equivalent method) is adequate to provide characterization sampling.

Based on these assumptions, Figures 3-1 and 3-2 were developed to depict possible scenarios for receptors and subsurface impact. Figure 3-1 indicates the conceptualization that the site has one exposure route, ingestion of soil through the mouth or nose. Inadvertent intrusion into the site (such as digging with a backhoe or drilling) could disturb the soil or unearth impacted soil and cause a contaminant release to possible receptors (such as site workers). Although site access is currently restricted by fencing, the potential for inadvertent disturbance exists. Figure 3-2 
Date: 10/27/97

Page 15 of 38

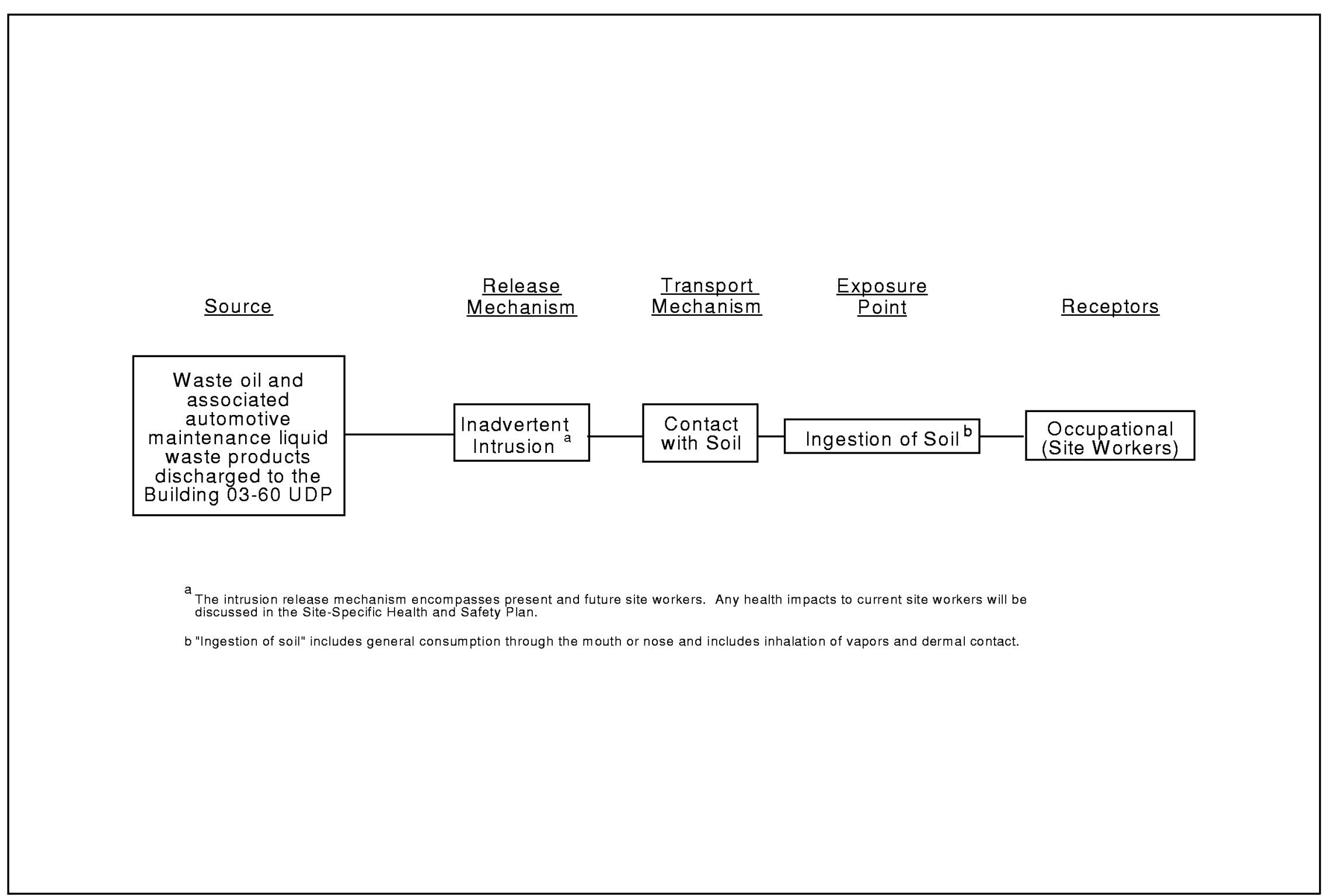

Figure 3-1

Exposure Pathway Conceptual Model 


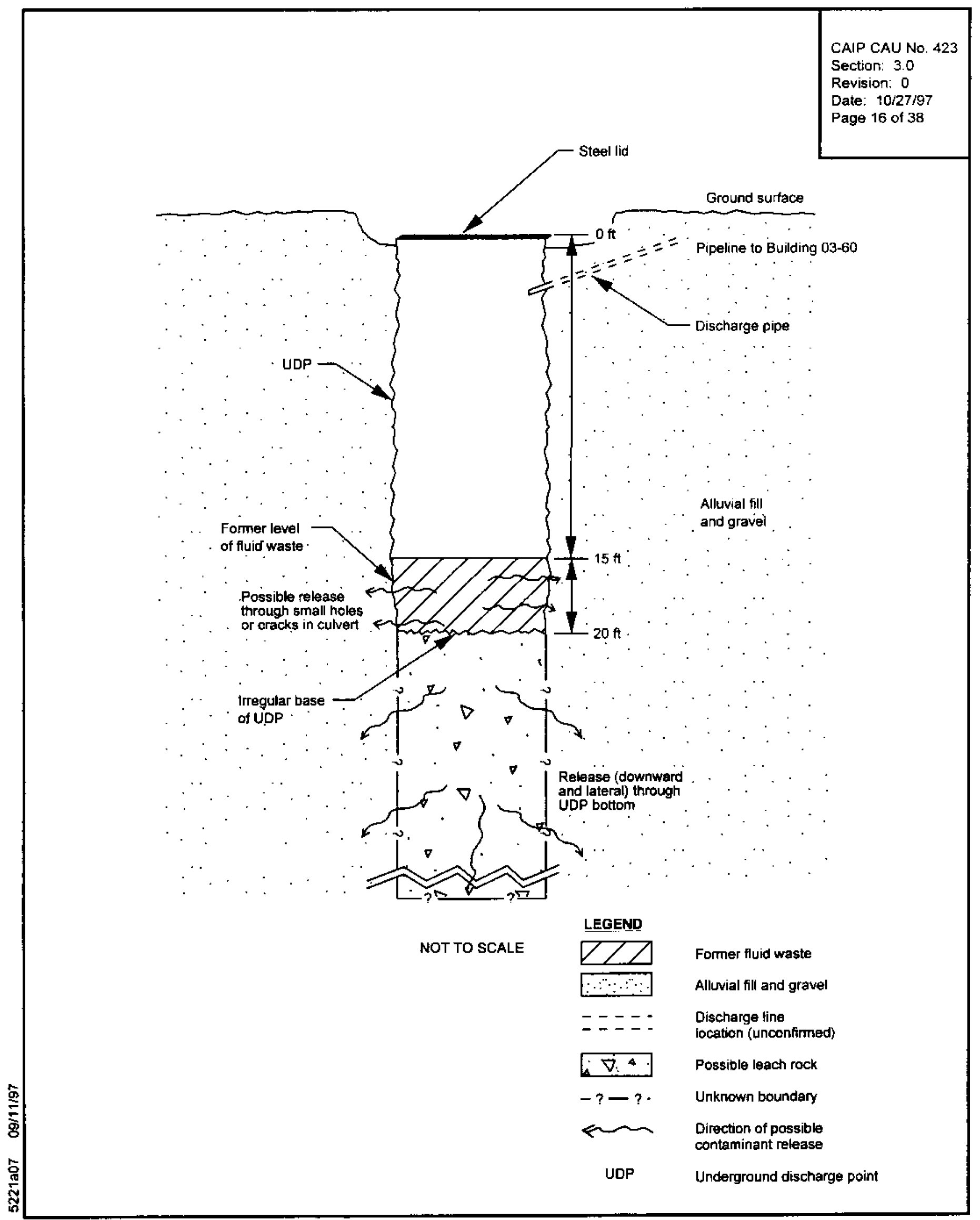

Figure 3-2 
indicates the conceptualization that a release to the soils surrounding the UDP has likely occurred

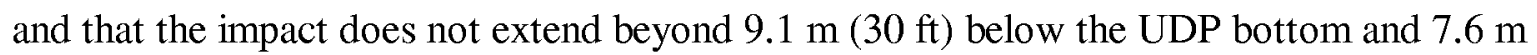
(25 ft) laterally from the center of the UDP. The most likely affected areas are located immediately beneath and lateral to the UDP bottom. Liquid waste would initially migrate laterally, then vertically downward. Lateral migration may also occur through hole/cracks in the UDP culvert sides. Subsurface variations may also contribute to lateral migration. It is assumed that the leach rock (if present) below the UDP bottom is homogeneous. Infiltration is limited to

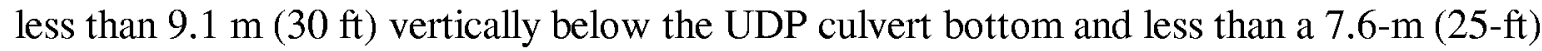
radius from the center of the UDP. Infiltration into the soils below and/or adjacent to the discharge line, either at the discharge line end(s) and/or via cracks or breaks along the length of the line, may also have occurred.

A groundwater impact is possible if downward migration is greater than approximately $91.4 \mathrm{~m}$ $(300 \mathrm{ft})$. If it is determined after sampling that groundwater may be impacted, the site may be rescoped, and the groundwater pathway will be investigated. However, based on the estimated depth to groundwater, the viscous nature of the waste oil, and the fine-grained soils, a groundwater impact is not anticipated.

\subsection{Contaminants of Potential Concern}

The previous waste oil sampling results (Attachment 3 of Appendix A) indicated the presence of volatile organic compounds, aromatics, chlorinated aromatics, and metals (below regulatory action levels). Based on process knowledge of liquid waste products from automotive maintenance activities as well as on the previous sampling results, it is recommended that subsurface soil samples collected in the Building 03-60 UDP study area be analyzed for:

- Total VOCs

- Total SVOCs

- Total RCRA metals

- Total PCBs

- Total petroleum hydrocarbons (TPH)

It should be noted that analysis for gamma-emitting radionuclides (i.e., gamma scan) will only be performed if field screening results indicate radionuclides above two times background. Radionuclides are not anticipated to be detected at this site. 


\subsection{Preliminary Action Levels}

Preliminary action levels for both on-site field screening methods and off-site analytical methods will be used to determine the presence of contamination.

The following action levels will be used for on-site field screening:

- VOC screening at 25 parts per million (ppm) or $2 \frac{1}{2}$ times background (closed-bag headspace), whichever is greater

- For TPH, the analytical concentration of $100 \mathrm{ppm}$ TPH or a field screening concentration that is comparable to an analytical concentration of $100 \mathrm{ppm} \mathrm{TPH}$

- For radiation (alpha, beta/gamma) screening, the presence of man-made radionuclides above two times background, or

- Beta/gamma activity levels > 0.5 millirem ( 5 microsieverts) per hour (dose rate criteria) at a distance of $30 \mathrm{~cm}$ (11.8 in.) above ground surface (DOE/NV, 1996d).

- Alpha-emitting radionuclides averaged over 100 square meters (1,076 square feet), which could result in airborne radioactivity levels $>1 / 50$ of a Derived Air Concentration.

- Field screening of material being handled, such as core samples, which indicate surface radioactivity values exceeding those listed in Table 2-2 of the NV/YMP Radiological Control Manual (DOE/NV, 1996d).

Off-site laboratory analytical results will also be compared to preliminary action levels to evaluate the need for possible corrective actions. The analytical data will be used to support the preparation of a Corrective Action Decision Document (CADD) in which various corrective action strategies will be examined. These preliminary action levels are as follows:

- RCRA contaminant concentrations above the NDEP Corrective Action Regulations (NDEP, 1996)

- TPH concentrations above the TPH limits per the Nevada Administrative Code (NAC) 445A2272 (NAC, 1996a) and NDEP Corrective Action Regulations (NDEP, 1996)

- Background concentrations of radioactive material or concentrations above those listed in the Offsite Radiation Exposure Review Project (ORERP), Phase II Soils Programs report (McArthur and Miller, 1989) 


\subsection{DQO Process Discussion}

A DQO Scoping meeting for CAU No. 423 was held in June, 1997. The product of this meeting was a worksheet following the EPA seven step DQO guidance outline (EPA, 1994). The worksheet is attached to this document as Appendix A. The DQO process was used to determine characterization procedures adequate to define the contamination produced by the UDP. The DQO process was also used to define stop points to provide guidance in unexpected situations during the investigation.

Laboratory analysis of the soil samples will provide the means for a quantitative measurement of the potential COCs. The analytical methods and minimum reporting limits for each analyte are provided in Table 3-1.

If environmental sample data indicate that no analytes are above the criteria presented in Section 3.3, then no further action will be recommended. Modeling of the likelihood of future increases in contaminant concentrations may be required to assist in these recommendations and decisions.

\section{Stop Points for Notification}

The following represent specific stop points that were determined during the DQO process to provide guidance on unexpected situations that may arise during the field investigation:

- If field screening results indicate that contamination is more extensive than predicted (i.e., drilling advances to the saturated zone), the field investigation will stop; NDEP will be notified; and the site will be rescoped.

- If radiation is encountered above field screening action levels (i.e., two times background), drilling will stop; the NDEP will be notified; and the need to initiate a Radiological Work Permit will be assessed.

- If operations need to stop because of unexpected site conditions, NDEP will be notified.

- If drilling encounters bit refusal that precludes successful investigation of the site, NDEP will be notified for decision concurrence.

- If conditions warrant changing the drilling method, NDEP will be notified, and the investigation will be rescoped. 
Table 3-1

Site Characterization Laboratory Analytical Requirements

(Page 1 of 2)

\begin{tabular}{|c|c|c|c|c|c|}
\hline Analyte & Medium $^{a}$ & $\begin{array}{l}\text { Analytical } \\
\text { Method }\end{array}$ & $\begin{array}{c}\text { Minimum } \\
\text { Reporting Limit }\end{array}$ & $\begin{array}{c}\text { Acceptable } \\
\text { Precision }^{\mathrm{b}} \\
\text { (RPD) } \\
\end{array}$ & $\begin{array}{c}\text { Acceptable } \\
\text { Accuracy } \\
(\% \mathrm{R}) \\
\end{array}$ \\
\hline \multirow[t]{2}{*}{ Total VOCs } & Water & \multirow[t]{2}{*}{$8260^{\circ}$} & \multirow{2}{*}{$\begin{array}{l}\text { Analyte-specific } \\
\text { estimated } \\
\text { quantitation limits }\end{array}$} & 14 & $60-132$ \\
\hline & Soil & & & 24 & $59-172$ \\
\hline \multirow[t]{2}{*}{ Total SVOCs } & Water & \multirow[t]{2}{*}{$8270^{\mathrm{c}}$} & \multirow{2}{*}{$\begin{array}{l}\text { Analyte-specific } \\
\text { estimated } \\
\text { quantitation limits }\end{array}$} & 50 & $5-230$ \\
\hline & Soil & & & 50 & $11-142$ \\
\hline $\begin{array}{l}\text { Total RCRA Metals } \\
\text { Arsenic } \\
\text { Barium } \\
\text { Cadmium } \\
\text { Chromium } \\
\text { Lead } \\
\text { Mercury } \\
\text { Selenium } \\
\text { Silver }\end{array}$ & Water & $6010 / 7470^{c}$ & $\begin{array}{c}10 \mu \mathrm{g} / \mathrm{L} \\
200 \mu \mathrm{g} / \mathrm{L} \\
5 \mu \mathrm{g} / \mathrm{L} \\
10 \mu \mathrm{g} / \mathrm{L} \\
3 \mu \mathrm{g} / \mathrm{L} \\
0.2 \mu \mathrm{g} / \mathrm{L} \\
5 \mu \mathrm{g} / \mathrm{L} \\
10 \mu \mathrm{g} / \mathrm{L}\end{array}$ & 20 & $75-125$ \\
\hline $\begin{array}{l}\text { Total RCRA Metals } \\
\text { Arsenic } \\
\text { Barium } \\
\text { Cadmium } \\
\text { Chromium } \\
\text { Lead } \\
\text { Mercury } \\
\text { Selenium } \\
\text { Silver }\end{array}$ & Soil & $6010 / 7470^{c}$ & $\begin{array}{c}2 \mathrm{mg} / \mathrm{kg} \\
40 \mathrm{mg} / \mathrm{kg} \\
1 \mathrm{mg} / \mathrm{kg} \\
2 \mathrm{mg} / \mathrm{kg} \\
0.6 \mathrm{mg} / \mathrm{kg} \\
0.1 \mathrm{mg} / \mathrm{kg} \\
1 \mathrm{mg} / \mathrm{kg} \\
2 \mathrm{mg} / \mathrm{kg}\end{array}$ & 20 & $75-125$ \\
\hline \multirow[t]{6}{*}{$\begin{array}{l}\text { Total Petroleum } \\
\text { Hydrocarbons }\end{array}$} & $\begin{array}{c}\text { Water } \\
\text { (gasoline) }\end{array}$ & \multirow[t]{6}{*}{8015 modified $^{c}$} & $1 \mathrm{mg} / \mathrm{L}$ & 20 & $25-145$ \\
\hline & $\begin{array}{l}\text { Water } \\
\text { (diesel) }\end{array}$ & & $1 \mathrm{mg} / \mathrm{L}$ & 20 & $25-145$ \\
\hline & $\begin{array}{l}\text { Water } \\
\text { (oil) }\end{array}$ & & $1 \mathrm{mg} / \mathrm{kg}$ & 20 & $25-145$ \\
\hline & $\begin{array}{c}\text { Soil } \\
\text { (gasoline) }\end{array}$ & & $1 \mathrm{mg} / \mathrm{kg}$ & 30 & $30-130$ \\
\hline & $\begin{array}{c}\text { Soil } \\
\text { (diesel) }\end{array}$ & & $30 \mathrm{mg} / \mathrm{kg}$ & 30 & $30-130$ \\
\hline & $\begin{array}{l}\text { Soil } \\
\text { (oil) }\end{array}$ & & $30 \mathrm{mg} / \mathrm{kg}$ & 30 & $30-130$ \\
\hline \multirow[t]{2}{*}{ Total PCBs } & Water & \multirow[t]{2}{*}{$8080^{c}$} & \multirow{2}{*}{$\begin{array}{l}\text { Analyte-specific } \\
\text { estimated } \\
\text { quantitation limits }\end{array}$} & 30 & $8-160$ \\
\hline & Soil & & & 50 & $8-139$ \\
\hline
\end{tabular}




\section{Table 3-1 \\ Site Characterization Laboratory Analytical Requirements (Page 2 of 2)}

\begin{tabular}{|c|c|c|c|c|c|}
\hline Analyte & Medium $^{\mathrm{a}}$ & $\begin{array}{l}\text { Analytical } \\
\text { Method }\end{array}$ & $\begin{array}{l}\text { Minimum } \\
\text { Reporting Limit }\end{array}$ & $\begin{array}{l}\text { Acceptable } \\
\text { Precision }^{\mathrm{b}} \\
\text { (RPD) }\end{array}$ & $\begin{array}{c}\text { Acceptable } \\
\text { Accuracy }^{\mathrm{b}} \\
(\% \mathrm{R})\end{array}$ \\
\hline \multirow{2}{*}{$\begin{array}{l}\text { Gamma } \\
\text { Spectroscopy } \\
\text { (Based on } \\
\text { Cesium-137) }\end{array}$} & Water & $\begin{array}{c}\text { EPA } 901.1^{\ominus} \text { or } \\
\text { LAL-91-SOP-0063 }\end{array}$ & \multirow{2}{*}{$\begin{array}{l}\text { Background levels } \\
\text { or } \\
\text { ORERPg }\end{array}$} & 20 & $80-120$ \\
\hline & Soil & $\begin{array}{l}\text { HASL } 300,4.5 .2 .3^{h} \\
\text { LAL-91-SOP-0064 }\end{array}$ & & 20 & $80-120$ \\
\hline
\end{tabular}

${ }_{b}^{\mathrm{a}} \mathrm{QC}$ (water) samples are included in table.

Precision and Accuracy requirements are parameter-specific and are referenced from the Contract Laboratory Program Statement of Work (EPA, 1990). The high-low range for all parameters for each method is displayed here, but the actual range will vary by analyte.

EPA Test Methods for Evaluating Solid Waste, 3rd edition, Parts 1-4, SW-846 (EPA, 1996)

Estimated Quantitation Limit (EQL) as given in Method SW-846, U.S. EPA (EPA, 1996)

${ }_{f}^{e}$ Prescribed Procedures for Measurement of Radioactivity in Drinking Water (EPA, 1980)

LAS Laboratories, 1996a, Standard Operating Procedure.

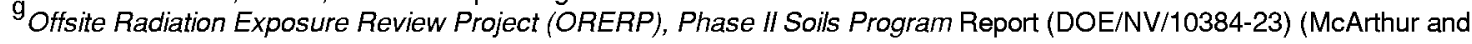
Miller, 1989)

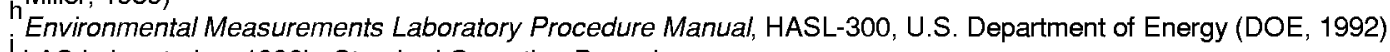

'LAS Laboratories, 1996b, Standard Operating Procedure.

$\mathrm{EPA}=\mathrm{U} . \mathrm{S}$. Environmental Protection Agency

$\mathrm{mg} / \mathrm{kg}=$ Milligram(s) per kilogram

$\mathrm{PCB}=$ Polychlorinated biphenyl(s)

$\mathrm{mg} / \mathrm{L}=$ Milligram(s) per liter

RCRA $=$ Resource Conservation and Recovery Act

$\mathrm{RPD}=$ Relative Percent Difference

SVOC = Semivolatile organic compound(s)

VOC = Volatile organic compound(s)

$\mu \mathrm{g} / \mathrm{L}=$ Microgram(s) per liter

$\% \mathrm{R}=$ Percent recovery

Note: Gamma Spectroscopy analysis will only be performed if field screening levels indicated the presence of gamma-emitting radionuclides at levels greater than two times background. 


\subsection{Field Investigation}

This section of the CAIP contains the sampling approach for investigating the Building 03-60 UDP, including the waste oil discharge line. All sampling activities will be conducted in compliance with the Industrial Sites QAPP (DOE/NV, 1996b) and other applicable, approved procedures which will be described in the site-specific field instructions. Quality assurance and quality control requirements for field and laboratory environmental sampling are contained in the Industrial Sites QAPP (DOE/NV, 1996b) and in Table 3-1. A description of the QC samples to be collected for this project will be included in site-specific field instructions.

\subsection{Sampling Approach}

The sampling approach for CAU No. 423 will consist of drilling a minimum of one borehole to investigate the presence of waste oil products directly beneath the UDP. Step-out borings will also be drilled if needed to evaluate the extent of lateral and vertical contaminant migration. Continuous field screening and environmental sampling will be conducted during the investigation, and the results will be utilized during the corrective action decision process. In the following sections, the drilling, field screening, sampling, and discharge line investigation approaches are described.

\subsubsection{Soil Borings}

In order to allow subsurface drilling directly into the UDP, a surface casing (larger in diameter than the drill string) will be installed within the culvert and then the annulus outside the surface casing will be filled with clean pea gravel (approximately 5.4 cubic meters [ 7 cubic yards]). This will enable a drill rig to position directly over the center of the UDP and samples to be collected directly from the most likely impacted area. One boring will then be advanced directly through the center of the UDP. After reaching the current bottom of the UDP at approximately $20 \mathrm{ft} b g \mathrm{~s}$, drilling will continue until two consecutive, $1.5-\mathrm{m}(5-\mathrm{ft})$ interval, non-detect field screening readings (for all three parameters) are obtained (if above $15.2 \mathrm{~m}$ [50 ft] bgs). If two consecutive, 1.5-m (5-ft) interval, non-detect field screening readings are not obtained above a depth of $15.2 \mathrm{~m}$ (50 ft) bgs, field screening will then be conducted at 3-m (10-ft) intervals; and drilling will continue until two consecutive, non-detect field screening readings are obtained or until groundwater is encountered, whichever occurs first. During drilling, ground surface will be referenced from the top of the UDP backfill. 
If COCs above the indicated field screening action levels (Section 3.3) are identified during advancement of the initial boring, a minimum of three step-out borings will be advanced to evaluate the extent of lateral and vertical contaminant migration. The initial step-out borings will be located in a roughly triangular pattern $7.6 \mathrm{~m}(25 \mathrm{ft})$ or less from the UDP center. Based on field screening results, additional step-outs (beyond the initial three) may also be needed to delineate the plume boundaries. At a minimum, step-out borings will be advanced to the lowest vertical extent of contamination (based on field screening readings) found in the UDP boring.

The dry sonic drilling method will be used to advance the holes. The method provides a continuous core from the surface to total depth from which to collect environmental samples and examine the native soil and/or leach rock beneath the UDP culvert. The dry sonic drilling method was selected over other investigative methods (i.e., trenching or hollow-stem auger) for the following reasons:

- The volume of investigation-derived waste (IDW) is significantly reduced.

- A vertical profile of the subsurface materials may be obtained via collection of continuous core.

- High quality, relatively undisturbed samples are provided.

- Drill rates are relatively fast, and most types of materials (e.g., leach rock or metal bottom of the UDP) can be penetrated.

A plan view of the UDP borehole location and proposed locations for step-out borings (if needed) is shown on Figure 4-1. Actual locations may be adjusted based on field observations.

\subsubsection{Field Screening}

Field screening tests will be performed for all borings. In the UDP center boring, field screening will be performed at 1.5-m (5-ft) intervals from the base of the UDP (approximately 6.1 $\mathrm{m}$ [20 ft] bgs) to approximately $15.2 \mathrm{~m}(50 \mathrm{ft}) \mathrm{bgs}$. If drilling should need to continue past 15.2 $\mathrm{m}(50 \mathrm{ft}) \mathrm{bgs}$, field screening will continue in $3.0-\mathrm{m}(10-\mathrm{ft})$ intervals to total depth. In any 


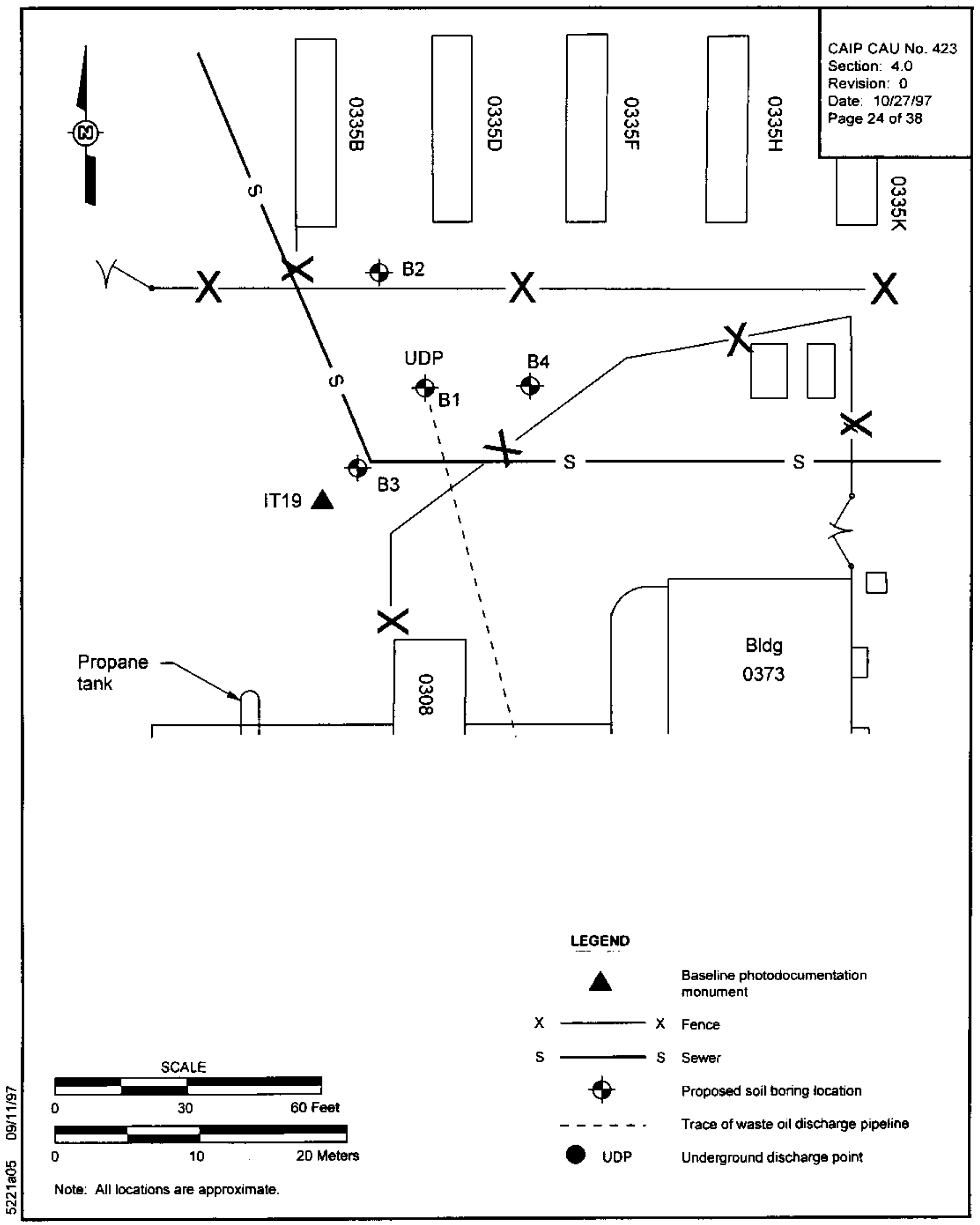

Figure 4-1

Proposed Borehole Locations, Building 03-60 UDP 
step-out borings, field screening will be conducted from ground surface to total depth in the same manner as described for the UDP center boring.

The field screening methods will consist of headspace testing for VOCs, TPH screening, and radiological screening for alpha and beta/gamma emitters. This field screening data will serve three purposes. First, the data will provide continuous semiquantitative measurement of the subsurface environmental impact (providing sufficient material is available to conduct the tests) for site characterization. Second, the data will provide a mechanism for guiding the investigation deeper, if necessary. If field screening results exceed the preliminary action levels listed in Section 3.3, then drilling will continue until two consecutive, non-detect results are recorded. Third, the data will be used to assist with the selection of samples to be submitted for laboratory analysis.

\subsubsection{Sampling Criteria}

Soil samples will be collected for laboratory analysis based on visual observations (e.g., areas of visible staining) and/or the results of field screening at $1.5-\mathrm{m}(5-\mathrm{ft})$ intervals to a depth of

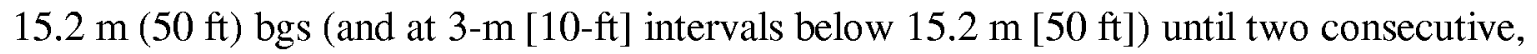
non-detect field screening samples are obtained. In step-out borings (if performed), samples will be collected for laboratory analysis from the highest field-screening interval and the lowest vertical, non-detect interval. If field screening does not detect any contamination in the step-out borings, a sample from the lowest interval will be submitted for confirmation of the non-detect field screening readings.

Proposed analytical parameters were selected based on process knowledge, the results of the 1996 waste oil characterization sampling (IT, 1996c), and requirements specified by the NDEP for waste characterization. The parameters, methods, and associated QC ranges for precision and accuracy measurements are specified in Table 3-1.

Soil samples will also be collected for evaluation of geotechnical parameters with regard to future corrective action strategies. The geotechnical analysis will be performed by an off-site, fixedbased laboratory. Analytical parameters and methods are presented in Table 4-1. 
Table 4-1

Geotechnical Analyses, Building 03-60 UDP

\begin{tabular}{||l|c||}
\hline \multicolumn{1}{|c|}{ Analysis } & Method \\
\hline \hline Initial moisture content & ASTM $^{\mathrm{a}}$ D 2216 \\
\hline Dry bulk density & $\mathrm{EM}^{\mathrm{b}}-1110-2-1906$ \\
\hline Calculated porosity & EM-1110-2-1906 \\
\hline Saturated/unsaturated hydraulic conductivity & ASTM D 5084 \\
\hline $\begin{array}{l}\text { Particle-size distribution (preferred method is hydrometer } \\
\text { distribution) }\end{array}$ & ASTM D 422 \\
\hline Water-release (moisture retention) curve & ASTM D 3152 \\
\hline Atterberg Limits & ASTM D 4318-93 \\
\hline Microbial Activity & Laboratory Specific \\
\hline \hline
\end{tabular}
aAnnual Book of ASTM Standards, Section 4, "Construction," Volume 04.08, Soil and Rock (1), and Volume
b4.09, "Soil and Rock" (11), 1996.
Onited States Army Corps of Engineers (USACE), Engineer Manual 1110-2-1906, "Laboratory Soils
Testing," Appendix II, 1970

ASTM = American Society for Testing and Materials

$\mathrm{EM} \quad=$ Engineering Manual

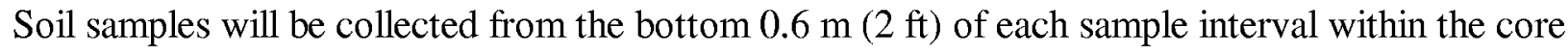
barrel sampler. Figure 4-2 is a generalized schematic of a core barrel sampler and the sequence to be followed for sample collection. Beginning at the nose of the core barrel, the first two portions will be retained for total VOCs and TPH-gasoline analysis, respectively. The next portion of the core will be retained for VOC and TPH field screening. The fourth portion will be retained for total SVOCs, PCBs, TPH-diesel, and RCRA metals analysis. The fifth portion will be analyzed for gamma-emitting radionuclides, if necessary. The remaining core will be used for analysis of geotechnical parameters. Samples will be submitted to the laboratory in brass sleeves and/or glass jars. The entire core will be field screened for alpha and beta/gamma radiological contamination during sample aliquot collection. 


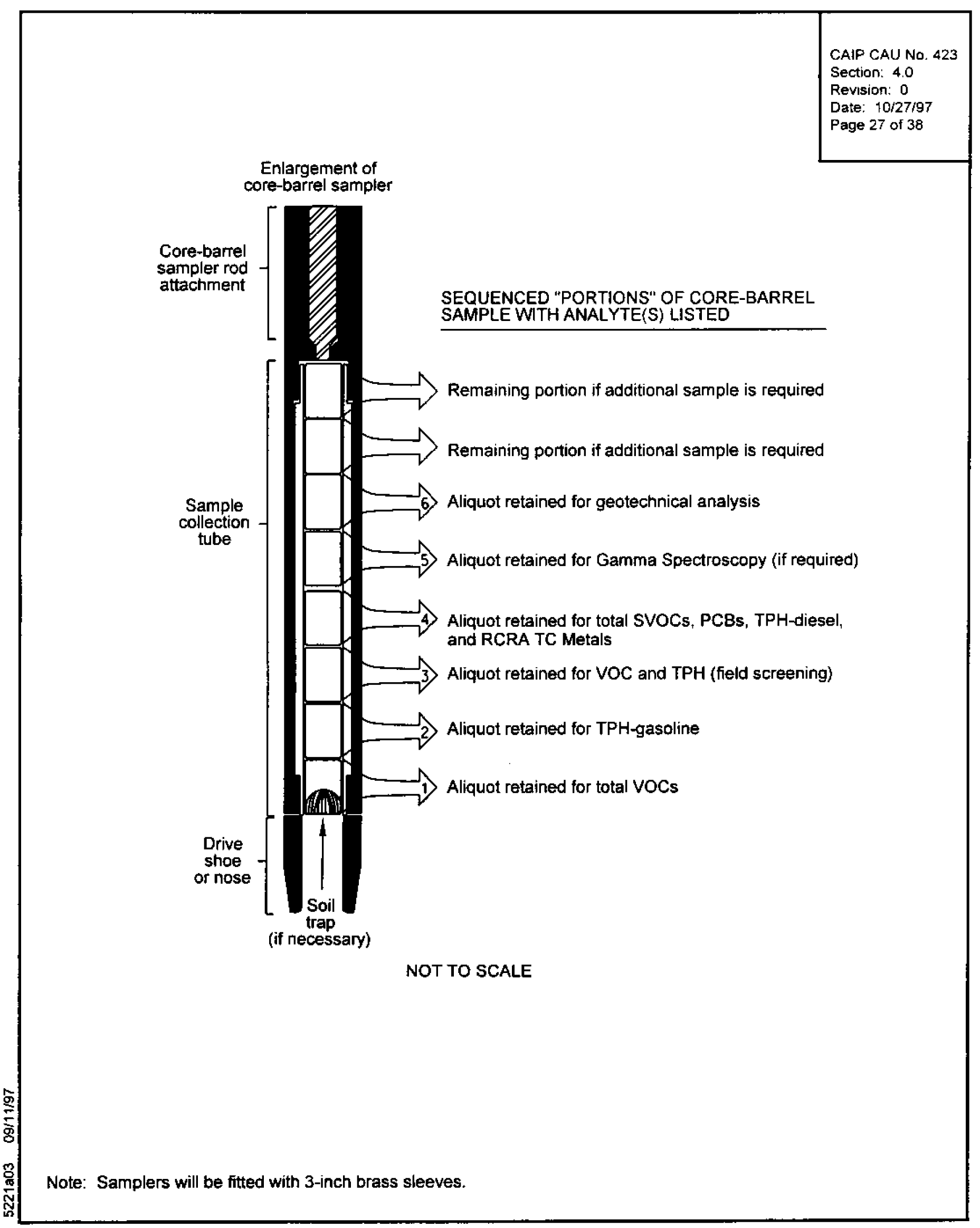

Figure 4-2 
Discretionary sampling points may also be selected for laboratory analysis based on a visual examination by the site supervisor/geologist. Selection criteria for discretionary samples could include:

- Moist or discolored zones

- Significant changes in soil grain size

- Increases in odor

All equipment which contacts the soil will be decontaminated in accordance with contractor's written and approved procedures consistent with the Environmental Restoration Division Procedure ERD-05-701, “Sampling Equipment Decontamination," Rev. 0 (DOE/NV, 1994b), or as appropriate for special equipment being decontaminated (i.e., steam-cleaning core barrels).

Clean core barrels shall be used for each sampling event. This will minimize the potential for cross-contamination between sample locations. All samples collected for laboratory analysis will be aliquots of fresh media (rather than reusing the sample media used for screening). Records will be kept of the soil description, field screening measurements, and all other relevant data. All pertinent and required sampling information (i.e., date, time, sample interval) will be documented in accordance with the Industrial Sites QAPP (DOE/NV, 1996b). Approved Chain of Custody procedures (IT, 1997c) will be followed to assure the defensibility of the data. 


\subsection{Waste Management}

Management of IDW will be based on regulatory requirements, field observations, and the results of laboratory analysis of the Building 03-60 UDP study area samples. Administrative controls (decontamination procedures and the characterization strategy) will minimize waste generated during the investigation.

Solid materials other than soil wastes are waste only by virtue of contact with contaminated media. The same is true of decontamination rinsate. Therefore, sampling and analysis of the IDW (other than soil from the borings), separate from site characterization analyses, will not be required. The data generated as a result of site characterization will be used to assign the appropriate waste type (i.e., ordinary, hydrocarbon, hazardous) to the IDW. Based on process knowledge and the previous sampling results, radioactive and mixed wastes are not anticipated at this site. The action levels for IDW contaminants are presented in Table 5-1.

Table 5-1

Action Levels for IDW Contaminants

\begin{tabular}{|c|c|c|c|}
\hline Parameter & Action Level & Source & Comments \\
\hline $\mathrm{TPH}^{\mathrm{a}}$ & $100 \mathrm{ppm}^{\mathrm{b}}$ & $\mathrm{NAC} 445 \mathrm{~A} 2272^{\mathrm{C}}$ & Regulated by the NDEP ${ }^{d}$ \\
\hline $\begin{array}{l}\text { Total VOCs }{ }^{e} \text {, SVOCs }{ }^{\dagger} \text { and } \\
\text { andRA metals }\end{array}$ & See note below & 40 CFR $261^{h}$ & --------------- \\
\hline Total PCBsi & $50 \mathrm{ppm}$ & $\begin{array}{l}40 \text { CFR } 761.1(b)^{j} \\
\text { NAC444.940 to } 444.9555^{k}\end{array}$ & $\begin{array}{l}\text { NDEP requires } \\
\text { manifesting as hazardous } \\
\text { waste for shipping and } \\
\text { disposal purposes. }\end{array}$ \\
\hline Radiological & Isotope specific & $\begin{array}{l}10 \text { CFR } 30.70 \text { ' Schedule A } \\
\text { "Exempt Concentrations" }\end{array}$ & 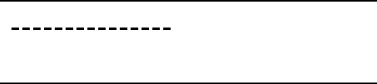 \\
\hline
\end{tabular}

a Total petroleum hydrocarbons

bart(s) per million

Nevada Administrative Code, 1996b

${ }_{\mathrm{i}}^{\mathrm{h}}$ Code of Federal Regulations, 1996a

devada Division of Environmental Protection

Polychlorinated biphenyl(s)

Volatile organic compound(s)

${ }_{\mathrm{k}}^{\mathrm{j}}$ Code of Federal Regulations, 1996b

${ }^{k}$ Nevada Administrative Code, 1990

Sernivolatile organic compound(s)

Code of Federal Regulations, 1994

${ }^{\mathrm{g}}$ Resource Conservation and Recovery Act

Note: Total VOCs, SVOCs, and metal concentrations of the samples will be determined through laboratory analysis. The laboratoryderived concentrations for soil samples (milligram/kilogram) will be divided by a factor of 20 and compared to the toxicity characteristic limit (milligram/liter) for hazardous parameters. If the total value divided by 20 is greater than the TC limit, IDW associated with these samples will be considered hazardous waste. 
Ordinary, hydrocarbon, or hazardous waste, if generated, will be managed and disposed of in accordance with applicable U.S. Department of Energy Orders, U.S. Department of Transportation (DOT) requirements, RCRA regulations, agreements and permits between DOE and NDEP, and site-specific requirements. Decontamination activities will be performed according to approved procedures (e.g., IT, 1997c).

\subsection{Waste Minimization}

Corrective action investigation activities, including the proposed field technique of dry sonic drilling, have been planned to minimize the amount of IDW generated. Borehole or soil waste that does not require management as radioactive or RCRA-regulated waste will be disposed of as ordinary waste. Other waste, such as disposable sampling and personal protective equipment (PPE), will be segregated to the greatest extent possible to avoid generation of hazardous, radioactive, or mixed waste. Hazardous materials will be controlled, minimizing generation of hazardous or mixed waste.

\subsection{Potential Waste Streams}

Process knowledge and previous sampling results indicate that hydrocarbon waste and potentially hazardous materials were released to the UDP. Radioactive or mixed wastes are not anticipated at this site. Although liquid waste has been removed from the UDP, it is unknown whether an impact has occurred to the surrounding soils. There is a potential that hydrocarbon, hazardous, and/or ordinary wastes will be generated during the field investigation activities. In addition, the reagents used in the TPH field-screening methods will produce small quantities of hazardous wastes.

\subsection{Investigation-Derived Waste Management}

Wastes generated during the investigation activities may include, but are not limited to, the following:

- Decontamination rinsate

- Contaminated disposable or reusable sampling equipment (such as plastic, paper, sample containers, aluminum foil, or hand augers)

- Personal protective equipment

- Contaminated soil (such as soil retained for headspace testing) 
- Soil contaminated by colorimetric TPH testing

- Contaminated core material

For administrative purposes, the waste will be managed as at least three waste streams: soil, contaminated solid trash, and liquid wastes such as decontamination rinsate. Each waste stream will be segregated, and additional segregation may occur within each waste stream. For example, the soil waste and decontamination rinsate will be segregated.

\subsubsection{Sanitary Waste Management}

Sanitary waste will be contained in plastic bags, dumpsters, or drums and transported to an Nevada Test Site (NTS)-managed or approved off-site sanitary waste landfill. Soils that are not regulated and meet the acceptance criteria for the NTS or approved off-site sanitary landfills will also be disposed of as sanitary waste.

\subsubsection{Low-Level Waste Management}

Radiological controls will not be instituted unless field screening or laboratory analytical results exceed two times background level (see Sections 3.2 and 3.3). Low-level waste, if generated, will be managed in accordance with DOE Orders and the requirements of the Nevada Test Site Waste Acceptance Criteria (NTSWAC) (DOE/NV, 1996e). Investigation-derived waste such as PPE will be placed in plastic bags marked with the date and associated borehole number. The bags will be placed in DOT-compliant drums (49 CFR 172) (CFR, 1997a) which will be properly labeled and locked or fitted with tamper-indicating devices. The drums will be staged at a designated Radioactive Materials Area pending disposal under NTSWAC requirements (DOE/NV, 1996e).

Low-level waste will be characterized in accordance with the requirements of the NTSWAC and the contractor-specific waste certification program plan and implementing procedures. Characterization will be based on laboratory results, field screening, process knowledge, or a combination thereof.

\subsubsection{Hazardous Waste Management}

Suspected hazardous wastes will be managed in accordance with RCRA and State of Nevada hazardous waste management regulations, interpreted as follows. Suspected hazardous wastes will be placed in DOT-compliant drums (49 CFR 172) (CFR, 1997a) which will be locked or fitted with tamper-indicating devices. The containers shall be compatible with the waste in accordance with the requirements of 40 CFR 265.172 (CFR, 1996c). Containers shall be handled 
and inspected in accordance with the requirements of 40 CFR 265.173 and 174, respectively (CFR, 1996c). Based on process knowledge, incompatible wastes shall be managed in accordance with 40 CFR 265.177 (CFR, 1996c) (i.e., shall not be placed in the same container), and they shall be separated so that in the event of a spill, leak, or release, incompatible wastes shall not contact one another. Wastes shall be containerized in a manner to comply with Subpart C of 40 CFR 265 (CFR, 1996c).

Hazardous wastes shall be characterized in accordance with the requirements of 40 CFR 261 (CFR, 1996a). Characterization will be based on laboratory results, field screening results, process knowledge, or a combination thereof. Waste pending characterization will be marked with "Awaiting Analysis" stickers until its regulatory status can be determined through evaluation of laboratory results. The determination of whether the waste is characteristic or listed will be based on the Code of Federal Regulations (CFR) Title 40 Part 261, "Identification and Listing of Hazardous Wastes" (CFR, 1996a). Waste shall be traceable to its source and/or samples considered analogous to the waste (such as waste drill core associated with a sample). Traceability shall be maintained by numbering containers and keeping appropriate records which trace waste to samples, areas, or products. After receipt of analytical results, hazardous wastes, if identified, will be labeled and marked in accordance with the requirements of 40 CFR 262.32 (CFR, 1997b) and State of Nevada requirements such as writing the EPA Waste Code on the hazardous waste label. Depending on the nature and amount of waste being generated, the applicable waste management control areas, such as a Satellite Accumulation Area or Hazardous Waste Accumulation Area, will be established.

Hazardous wastes will be accumulated at the site of generation for less than 90 days in accordance with 40 CFR 262.34 (CFR, 1997b). Prior to 90 days after the accumulation start date as specified in 40 CFR 262.34(a) (CFR, 1997b) or generation of wastes in excess of quantity limits specified in 40 CFR 262.34(c)(1) (CFR, 1997b), the waste will be shipped to a permitted hazardous waste treatment, storage, or disposal facility. The waste will be shipped by an appropriately licensed and permitted hazardous waste hauler. A Uniform Hazardous Waste Manifest shall be completed prior to shipping hazardous waste in accordance with the requirements of 40 CFR 262.20, 262.21, 262.22, and 262.23 (CFR, 1997b). A copy of the manifest shall be provided to the State of Nevada in accordance with state regulatory requirements. 


\subsubsection{Hydrocarbon Waste Management}

Hydrocarbon waste such as contaminated soil containing more than 100 ppm TPH will be properly containerized in bags or drums and will be transported to an appropriately permitted hydrocarbon waste management facility after the waste is fully characterized. Hydrocarbon waste which has come in contact or has had the potential to contact radiologically contaminated media (e.g., cuttings) is to be considered radiological waste and managed in accordance with the handling procedures for low-level radiological waste (see Section 5.6).

\subsubsection{Mixed Waste Management}

Mixed waste, if generated, shall be managed in accordance with RCRA (40 CFR 262) (CFR, 1997b) and State of Nevada (NAC444) (NAC, 1990) regulations as well as DOE requirements for radioactive waste, interpreted as follows. Where there is a conflict in regulations or requirements, the most stringent shall apply. For example, the 90 -day accumulation time limit and weekly inspections per RCRA regulations will be applied to mixed waste even though it is not required for radioactive waste. Conversely, while RCRA does not require documented traceability, the waste acceptance program for low-level radioactive waste does; therefore, traceability shall be documented as described in Section 5.5. In general, mixed waste shall be managed in the same manner as hazardous waste, with added mandatory radioactive waste management program requirements. Suspected mixed waste will be managed in accordance with applicable regulations and requirements and will be marked with "Awaiting Analysis" stickers pending characterization and confirmation of its regulatory status. However, mixed waste shall be transported to the NTS transuranic waste storage pad for storage pending treatment or disposal. Mixed waste with hazardous waste constituents below land disposal restrictions may be disposed of at the NTS Area 5 Radioactive Waste Management Site. Mixed waste not meeting land disposal restrictions will remain in Area 5 and require development of a treatment plan under the requirements of the Mutual Consent Order between DOE and the State of Nevada (NDEP, 1995). 


\subsection{Duration and Records Availability}

\subsection{Duration}

Following submission of the final CAIP to the Project Manager, DOE/NV Industrial Sites Subproject, the following is a tentative schedule of activities (in calendar days):

- Day 0: Preparation for field work will begin.

- Day 65: NDEP will be notified regarding the field work start date.

- Day 71: The field work, including drilling, field screening, and sampling, will begin.

- Day 91: The field work will be completed and samples shipped to the laboratory for analysis.

- Day 161: The quality-assured laboratory analytical sample data will be available for NDEP review.

- Day 238: The CADD will be submitted to NDEP.

The following information will be reported in the CADD:

- Introduction, including purpose, scope, an FFACO cross-walk, and a discussion about the need for further action

- The results of the corrective action investigation

- A corrective measures study, including initial screening of alternatives, evaluation of alternatives, and comparison of alternatives

- The recommended alternative

\subsection{Records Availability}

This document is available in the DOE public reading rooms located in Las Vegas and Carson City, Nevada, or by contacting the DOE Project Manager. Historic information and documents referenced in this plan are retained in the project files and can be obtained through written request to the Project Manager, DOE/NV Industrial Sites Subproject. 


\subsection{References}

ASTM, see American Society for Testing and Materials.

American Society for Testing and Materials. 1996. Sections 04.08 and 04.09, "Soil and Rock." In Annual Book of ASTM Standards. Philadelphia, PA.

CFR, see Code of Federal Regulations.

Code of Federal Regulations. 1994. 10 CFR Part 30.70, "Schedule A - Exempt

Concentrations." Washington, DC: U.S. Government Printing Office.

Code of Federal Regulations. 1996a. 40 CFR Part 261, "Identification and List of Hazardous Waste." Washington, DC: U.S. Government Printing Office.

Code of Federal Regulations. 1996b. 40 CFR Part 761.1(b), "Polychlorinated Biphenyls (PCBs) Manufacturing, Processing, Distribution in Commerce, and Use Prohibitions." Washington, DC: U.S. Government Printing Office.

Code of Federal Regulations. 1996c. 40 CFR Part 265, "Interim Status Standards for Owners and Operators of Hazardous Waste Treatment, Storage, and Disposal Facilities." Washington, DC: U.S. Government Printing Office.

Code of Federal Regulations. 1997a. 49 CFR Part 172, "Hazardous Materials Table, Special Provisions, Hazardous Materials Communications, Emergency Response Information, and Training Requirements." Washington, DC: U.S. Government Printing Office.

Code of Federal Regulations. 1997b. 40 CFR Part 262, "Standards Applicable to Generators of Hazardous Waste." Washington, DC: U.S. Government Printing Office.

DOE/NV, see U.S. Department of Energy, Nevada Operations Office.

EG\&G. 1988. Aerial Photograph of Tonopah Test Range Area 3 Compound. Perf. No. 5956, Frame 23. 10 April.

EPA, see U.S. Environmental Protection Agency.

FFACO, see Federal Facility Agreement and Consent Order.

Federal Facility Agreement and Consent Order. 1996. Agreed to by the State of Nevada, the U.S. Department of Energy, and the U.S. Department of Defense.

IT, see IT Corporation. 
IT Corporation. 1994. Inspection of Building Structures at Sandia National

Laboratories/Tonopah Test Range, August 1994. Prepared for Sandia National Laboratories. Albuquerque, NM.

IT Corporation. 1996a. "Field Activity Daily Logs, Site Photographs, and Sample Collection Logs, Building 03-60 UDP Field Activities." Las Vegas, NV.

IT Corporation. 1996b. IT Corporation Internal Memo from M. Doe to R. Dubiskas, Re: Field Effort Results, Building 03-60, Tonopah Test Range, 21 March. Las Vegas, NV.

IT Corporation. 1996c. Letter to Mr. K. Cabble, DOE/NV, from Mr. R. Dubiskas, IT Corporation, Re: Records for Hazardous Waste Identification of Building 03-60 Waste Oil Underground Discharge Point, 2 July. Las Vegas, NV.

IT Corporation. 1997a. Initial Surface Geophysical Survey Report for the Tonopah Test Range Environmental Restoration Sites, DOE/NV-10972--93. Las Vegas, NV.

IT Corporation. 1997b. Field Activity Daily Log, "Building 03-60 Field Measurements," 30 June. Las Vegas, NV.

IT Corporation. 1997c. IT Corporation Las Vegas Program Procedures Manual, ITLV/1993/05. Las Vegas, NV.

LAS Laboratories, Inc. 1996a. "Sample Preparations and Analysis for Gamma Activity in Aqueous Samples," Standard Operations Procedure LAL-91-SOP-0063. Las Vegas, NV.

LAS Laboratories, Inc. 1996b. "Sample Preparations and Analysis for Gamma Activity in Solids," Standard Operations Procedure LAL-91-SOP-0064. Las Vegas, NV.

McArthur, R. D., and F.L. Miller, Jr. 1989. Offsite Radiation Exposure Review Project (ORERP), Phase II Soils Programs, DOE/NV/10384-23. Las Vegas, NV: Desert Research Institute.

NAC, see Nevada Administrative Code.

Nevada Administrative Code. 1990. "Solid Waste Disposal," NAC444.940-444.9555. Carson City, NV.

Nevada Administrative Code. 1996a. NAC445A. Nevada Revised Statute 445A2272, "Contamination of Soil: Establishment of Action Levels." 3 October. Carson City, NV.

Nevada Administrative Code. 1996b. “Storage Tanks," NAC459.9973. Carson City, NV.

NDEP, see Nevada Division of Environmental Protection. 
Nevada Division of Environmental Protection. 1995. "Mutual Consent Agreement Between the State of Nevada and the Department of Energy for the Storage of Low-Level Land Disposal Restricted Mixed Waste." Transmittal from P. Liebendorfer (NDEP) to D. Elle (DOE/NV), 7 June. Carson City, NV.

Nevada Division of Environmental Protection. 1996. Corrective Action Regulations. Carson City, NV.

SNL, see Sandia National Laboratories.

Sandia National Laboratories. 1989. Sandia Master Utilities Plan-Plot Plan, Mechanical Utilities West. Albuquerque, NM.

USACE, see U.S. Army Corps of Engineers.

United States Army Corps of Engineers. 1970. "Laboratory Soils Testing." In Engineering Manual 1110-2-1906, Appendix II. Washington, DC.

U.S. Department of Energy. 1992. Environmental Measurements Laboratory Procedures Manual, HASL-300, 27th Edition, Volume 1. New York, NY.

U.S. Department of Energy, Nevada Operations Office. 1994a. Project Management Plan, Rev. 0. Las Vegas, NV.

U.S. Department of Energy, Nevada Operations Office. 1994b. "Sampling Equipment Decontamination," ERD-05-701, Rev. 0. Las Vegas, NV.

U.S. Department of Energy, Nevada Operations Office. 1996a. Corrective Action Unit Work Plan, Tonopah Test Range, Nevada. Las Vegas, NV.

U.S. Department of Energy, Nevada Operations Office. 1996b. Industrial Sites Quality Assurance Project Plan, Nevada Test Site, Nevada, Rev. 1, DOE/NV--372. Las Vegas, NV.

U.S. Department of Energy, Nevada Operations Office. 1996c. Environmental Restoration Project Health and Safety Plan, Rev. 2. Las Vegas, NV.

U.S. Department of Energy, Nevada Operations Office. 1996d. NV/YMP Radiological Control Manual, Rev. 2, DOE/NV 10630-59. Las Vegas, NV.

U.S. Department of Energy, Nevada Operations Office. 1996e. Nevada Test Site Waste Acceptance Criteria, NTSWAC, Rev. 0. Las Vegas, NV.

U.S. Environmental Protection Agency. 1980. Prescribed Procedures for Measurement of Radioactivity in Drinking Water. Washington, DC. 
U.S. Environmental Protection Agency. 1990. Contract Laboratory Program Laboratory Statement of Work, OLM.01.0-0.6/ILM.03.0. Washington, DC.

U.S. Environmental Protection Agency. 1994. Guidance for the Data Quality Objectives Process, EPA QA/G-4. Washington, DC.

U.S. Environmental Protection Agency. 1996. Test Methods for Evaluating Solid Waste, Physical/Chemical Methods, SW-846, 3rd Edition, CDROM, PB89-148076. Washington, DC. 


\section{Appendix A}

\section{Data Quality Objectives Worksheet}




\section{DATA QUALITY OBJECTIVES WORKSHEET FOR THE BUILDING 360 UNDERGROUND DISCHARGE POINT - CAU NO. 423}

Results of the Data Quality Objectives (DQOs) Scoping Meeting: The following notes are based on the DQO meeting held by the members of the Scoping Team (see below) on June 3, 1997. These notes follow the outline of the DQO guidance (EPA, 1994). The steps systematically build on the data acquired during background research for the CAU No. 423 Corrective Action Investigation Plan (CAIP). Copies of the background data are available in the project files of IT Corporation in Las Vegas. The operational details of the CAIP are summarized in Step VII of this worksheet.

\section{Team Members:}

\section{Scoping Team}

DOE/NV

Janet Appenzeller-Wing

Kevin Cabble

Lori Arent

NDEP

Dean Mierau

Harry van Drielen

Bechtel

Dave Madsen

Steve Nacht

\section{Core Decision Team}

Janet Appenzeller-Wing

Kevin Cabble

Kenneth Beach

Dave Madsen

\section{Primary Decision Makers}

Janet Appenzeller-Wing

Kevin Cabble

Kenneth Beach

Dave Madsen
IT Corporation

Kenneth Beach

Randy Dubiskas

Barbara Deshler

Syl Hersh

Jeanne Wightman

Cheryl Prince

Bonnie Blake 


\section{DATA QUALITY OBJECTIVES WORKSHEET}

\section{PROBLEM DESCRIPTION}

A. State the Problem: Regulated wastes may have been released into the subsurface at CAU No. 423 (CAS 03-02-002-0308).

\section{B. Summarize the contamination problem - combine the relevant background information into a concise description of the problem to be resolved.}

\section{Problem to be resolved}

Determine whether the former contents of the Building 03-60 Underground Discharge Point (UDP) in Area 3 of the Tonopah Test Range (TTR) have migrated beyond the UDP physical boundaries. If so, determine whether these materials are regulated contaminants and if they have impacted underlying soil or groundwater above regulatory action levels or to the extent that a hazard is posed to potential receptors. If an impact has occurred, determine the lateral and vertical extent in order to close the site under Nevada Division of Environmental Protection (NDEP), Resource Conservation and Recovery Act (RCRA), and Department of Energy (DOE) requirements.

\section{Describe the site history and known or suspected sources of contamination} Building 03-60, in the Area 3 compound at the Tonopah Test Range (TTR), was constructed in 1962 and is used as a light-duty fleet shop. Originally, waste oils were drained from Building 03-60 to Septic Tank 33-12 and the associated leachfield (CAU No. 427). After the septic tank was abandoned, the waste oil products (including waste anti-freeze, waste motor oil, and waste hydraulic oil) were discharged into a sump at the northwest corner of Building 03-60. A gravity-fed discharge line from the sump carried the waste oil to a point approximately 240 feet to the northwest where the line fed into what was originally thought to be an underground storage tank (UST). The specific time frame of fluid discharge to the sump is unknown, but may have been during the period from 1965 to 1989 or 1990.

In July 1993, a ground-penetrating radar geophysical survey was performed to confirm the UST location. In addition, the waste oil line was traced with an electromagnetic line tracer from the UST to Building 03-60.

During a March 1994, inspection of Building 03-60, the sump could not be located and was suspected to be sealed beneath a more recently emplaced concrete flooring slab. The upgradient end of the discharge line was also not found. Although Building 03-60 is still active, it is assumed that the discharge line and sump are inactive and that no contributions are being made to the UDP from any source.

On March 20, 1996, a soil excavation effort was held to locate the buried waste oil tank. As a result of this effort, it was determined that an underground storage tank was not present. Instead, an underground discharge point (UDP) consisting of a 
42-inch diameter corrugated culvert, set vertically in the ground, was found at a depth of 2 feet below surface grade. The culvert opening was covered by a 44-inch diameter, 1/2-inch thick, fabricated steel lid. Approximately 12 inches below the rim was a $13 / 4$-inch diameter galvanized pipe that is believed to be the downgradient end of the discharge line from Building 03-60. A black liquid with a strong hydrocarbon odor was visible 15 feet below the culvert rim. The liquid was determined to be approximately 5 feet deep. No rings, indicative of higher fluid levels, were noted. It is unknown whether releases from the UDP into the surrounding subsurface have occurred. The location of Building 03-60, the waste oil line, and the UDP are shown on the site map and aerial photograph in Attachment 1. Ground-level photographs of the UDP taken during the excavation activities are shown in Attachment 2.

Following collection and analysis of a waste oil sample in April 1996, the liquid in the UDP was removed (approximately 400 gallons). However, a small amount of residual sludge is believed to remain at the bottom of the UDP culvert.

The specific configuration of the UDP is unknown; however, a gravel layer, or some type of irregular base, is believed to exist at the bottom of the UDP. If gravel is present, it may be indicative of the presence of a gravel or leach rock column of unknown vertical extent below the bottom of the UDP. If the UDP base is concrete, it may indicate the UDP is part of a concrete holding tank below the UDP base (unlikely).

Uncertainties:

- Quantity of waste disposed

- Time frame of UDP operation

- UDP construction configuration (below culvert bottom)

- Sump location and the possibility of discharge line connection to other buildings

\section{List known or potential routes of migration}

Known routes of migration have not been established. Potential routes include the following conceptual models:

\section{Primary Model}

a. Infiltration of contaminants in the form of liquid waste into the soil directly below the corrugated culvert UDP. Liquid waste would initially migrate laterally, then vertically downward. Lateral migration may also occur through hole/cracks in the UDP culvert sides. Subsurface variations may also contribute to lateral migration. It is assumed that the leachrock (if present) below the UDP bottom is homogeneous.

b. Infiltration limited to less than 30 feet of vertical below the UDP culvert bottom and less than a 25 -foot radius of lateral migration from the center of the UDP. 
c. Infiltration into the soils below and/or adjacent to the discharge line, either at the discharge line end(s) and/or via cracks or breaks along the length of the line.

\section{Alternate Model}

a. Infiltration greater than 30 feet of vertical migration beneath UDP bottom and greater than 25 feet lateral migration.

b. If migration is greater than approximately 360 feet in the downward direction, the COCs have potentially contaminated groundwater.

\section{List known human and environmental receptors}

1. On-site personnel - potential exists for inadvertent intrusion

2. Plants and animals - potential for exposure is assumed to be low

3. Groundwater - low potential for contaminant impact due to depth to groundwater

4. Other worker scenarios - to be addressed in Corrective Action Plan (CAP) and the Site-Specific Health and Safety Plan (SSHASP)

\section{E. Define the exposure scenario}

\section{Define the exposure pathway(s)}

a. Oral ingestion, inhalation, or dermal contact (absorption) of constituents of concern in the soil after inadvertent excavation.

b. Exposure potential related to groundwater contamination which is estimated to be at least 360 feet below the site.

\section{Define the current and future land use}

The Building 03-60 UDP area is currently used for fleet maintenance and is classified as light industrial. Future land use is also anticipated to be light industrial.

\section{Define applicable or relevant and appropriate requirements (ARARs)}

The following guidelines will be used to establish screening levels in order to establish stop points for the characterization activities: Nevada Division of Environmental Protection (NDEP) Corrective Action Levels for hazardous constituents, metals, TPH, and PCBs, and DOE NTS/YMP RadCon Manual (DOE/NV, 1996d, Rev. 2) Table 2.2 screening criteria for radiological constituents. Any potential remediation and/or closure activities to be conducted on the site will be conducted using NDEP-mandated risk-based evaluation methods for hazardous and TPH constituents (e.g., Risk-based Corrective Action Guidance) in order to support one of the following options:

a. Closure in place.

b. Partial remediation and closure in place.

c. Remediation.

Note: ARARs will be discussed in additional detail in the CAIP. 


\section{Develop the exposure scenario}

The exposure scenario will be discussed in additional detail in the SSHASP and the

CAIP. The main exposure scenarios include the following:

a. On-site personnel (field workers) - Ingestion, inhalation or dermal contact with contaminated soil or airborne dust as a result of inadvertent intrusion into contaminated material during site activities.

b. Plants and animals - Minimum or negligible impact to vegetation. Ingestion of or dermal contact with contaminated soil unlikely but possible as a result of animal burrowing or digging activities.

c. Groundwater - Exposure to groundwater would only occur if subsurface investigation activities extended to approximately 360 feet below ground surface or if groundwater was impacted such that contaminants were detected in nearby supply wells.

\section{F. Specify the available resources}

\section{Specify monetary budget for the field investigation}

Monetary budget has been established as determined by the DOE/NV baseline.

\section{Equipment resources}

Equipment resources needed to accomplish the specified investigation tasks will include drilling and sampling equipment.

\section{Manpower resources}

The appropriate level of manpower resources will be utilized to accomplish the investigation tasks within specified time, budget, and health and safety constraints. Manpower resources will likely include, at a minimum, a 2 to 3 person field crew to oversee drilling activities, log soil characteristics, conduct field screening, collect soil samples for laboratory analysis, and document ongoing field activities. 


\section{IDENTIFY THE DECISION}

\section{A. Select the appropriate decision for the current phase of the site assessment process}

1. Contaminant Identification - Determine, with a Yes or No answer, whether regulated contaminants are present.

2. Action level exceedence - If regulated contaminants are present, determine with a Yes or No answer, whether contamination exceeds NDEP Corrective Action Levels or DOE NTS/YMP RadCon Table 2.2 radiological screening levels (DOE/NV, 1996d).

3. Contaminant migration - If regulated contaminants exceed screening levels, determine with a Yes or No answer whether regulated contaminant concentrations exceed the spatial boundaries proposed in the conceptual model for the site.

The level of management responsible for each decision is the DOE Subproject Manager in communication with the NDEP point of contact.

\section{B. Identify relationships among decisions}

\section{Prioritize decisions}

$1>2>3$

\section{Determine the logical sequence of actions}

The following sequence of actions will be considered in greater detail in the CADD; however, because data obtained during the corrective action investigation will provide the basis for the CADD, the following actions must also be considered at this time.

a. Contaminant Identification -

(1) If regulated contaminants have not been identified in the Building 03-60 UDP study area, then further assessment is not necessary. (No answer)

(2) If regulated contaminants have been identified in the Building 03-60 UDP study area, then further assessment is necessary; go to Step b. (Yes answer)

b. Action Level Exceedence -

(1) If the Building 03-60 UDP study area has not been impacted above applicable screening levels and will not be impacted further, then further assessment at this location is not necessary; go directly to CAP. (No answer)

(2) If the Building 03-60 UDP study area has been impacted above applicable screening levels, further assessment may be warranted; if so, go to Step c. (Yes answer) 
c. Contaminant Migration -

(1) If regulated constituents exceed the proposed spatial boundaries, then the conceptual model needs modification, and further assessment is required to evaluate the new (alternate) model. If so, mitigate imminent hazards; rescope investigation; submit revised CAIP. (No answer)

(2) If regulated constituents do not exceed the proposed spatial boundaries, then the conceptual model does not need to be modified, and further assessment at this location is not necessary. (Yes answer)

\section{IDENTIFY THE INPUTS TO THE DECISION}

\section{A. List types of contaminants and affected media}

On April 10, 1996, a homogenized waste oil sample was obtained for laboratory analysis of volatile organic compounds (VOCs), semivolatile organic compounds (SVOCs), RCRA Toxicity Characteristic (TC) metals, total pesticides, total polychlorinated biphenyls (PCBs), flashpoint, and radionuclides (IT, 1996c). Detected analytes included volatile organic compounds, aromatics, and chlorinated aromatics. A table listing the analytical results for the detected parameters is provided as Attachment 3. Results of a waste determination (Attachment 4) indicated the UDP waste liquid contained an "F002" listed waste in the form of orthodichlorobenzene (1,2-dichlorobenzene).

It is recommended that subsurface soil samples collected in the Building 03-60 UDP study area be analyzed for:
a. Total VOCs
b. Total SVOCs
c. Total RCRA metals
d. Total PCBs
e. TPH
f. Gamma-emitting radionuclides (i.e., gamma scan) (if field screening results indicate radionuclides above two times background)

If contaminants have migrated beyond the UDP confines, affected media include subsurface soil and may include groundwater. The extent to which these contaminants may have impacted surrounding and underlying soil and/or groundwater is currently not known but must be determined in order to close the site under NDEP, RCRA, and DOE requirements. 


\section{DATA QUALITY OBJECTIVES WORKSHEET}

\section{B. Identify the information inputs needed to resolve the decision, and how to generate the necessary data}

Information is needed on contaminant identity, the potential for action level exceedence, and the extent of contaminant migration. Listed below are the methods to be used to generate the necessary data:

1. Contaminant Identification:

a. Collect subsurface soil samples via drilling.

b. Conduct field screening for selected parameters.

c. Obtain analytical chemical data results.

2. Action Level Exceedence:

a. Obtain analytical chemical data results.

b. Determine regulatory action levels.

b. Review results against regulatory action levels.

3. Contaminant Migration:

a. Evaluate the boundaries of contaminant migration from indicator parameters and/or analyses of soils for the parameters listed in Section III.A.

b. Determine the soil moisture content below and adjacent to the UDP from field screening results and/or laboratory analysis of geotechnical soil parameters.

c. Determine soil physical characteristics (hydrological and geotechnical) via in situ testing or soil sampling and laboratory analysis of geotechnical parameters.

d. Based on process knowledge, modeling, and analysis of soil parameters and infiltration potential, evaluate the capacity for sludge to generate liquid waste, and the capacity for migration to continue and increase in the future.

4. Waste Management: NTSWAC analyses (DOE/NV, 1996e)

\section{Identify potential sources for each environmental input and list those inputs that are obtained through environmental measurements - identify existing sources of information that can support the decision}

The following investigative strategies have been listed here as possible methods for gathering the data needed to address the objectives of the corrective action investigation. Additional information on the actual investigative approach selected for field implementation will be discussed in the CADD. 


\section{DATA QUALITY OBJECTIVES WORKSHEET}

Existing sources of information will be listed in the references section of the CAIP. Potential sources, all of which require environmental measurements, for each environmental input include:

1. Vertical borings in and adjacent to the UDP - drill one boring directly through center of UDP; conduct a minimum of three step-out borings around the UDP to define lateral extent of contamination

2. Angled borings beneath the UDP - possible (but not preferred) alternative for obtaining subsurface data in UDP vicinity

3. Pressure testing or swabbing the waste oil line - determine if line may have other connections, if all liquid waste has been drained in the line, or if the line may have cracks or leaks along its length

4. Test pits along waste oil line - use a backhoe to excavate small pits to evaluate extent and magnitude of leakage (if present) along waste oil discharge line

5. Soil gas survey (active or passive) - measure flux of gasses by installing subsurface monitoring points around the UDP

6. Groundwater monitoring wells - install as needed if impact is likely

7. Hydrologic data - review existing hydrologic data from TTR water wells, and collect undisturbed soil samples for hydrologic/geotechnical analyses

\section{Determine the basis for establishing contaminant-specific action level(s) - list the possible basis for establishing the action level (e.g., regulatory threshold, risk or exposure assessment, technological limits, reference based, standards, etc.)}

The relationship of contaminant concentrations identified in the soils surrounding the Building 03-60 UDP to specified action levels will be considered during formulation of the CADD. However, designation and consideration of these action levels during the corrective action investigation phase is necessary: (1) because data collected during the corrective action investigation phase will be used to directly support formulation of the CADD, and (2) to ensure that data collected during the corrective action investigation phase are adequate to address the data needs of the CADD with regard to appropriate analytical parameters and detection limits.

Contaminant-specific action levels have been identified as follows:

1. Risk-based levels through the implementation of RCRA, CERCLA, and/or ASTM risk assessment techniques, as necessary and/or appropriate.

2. NDEP Corrective Action Levels for hazardous, metallic, and PCB constituents, and application of DOE NV/YMP RadCon Manual Table 2.2 standards for radionuclides (DOE/NV, 1996d).

3. RCRA toxicity characteristic concentrations (40 CFR 261.24) and RCRA TC and RCRA F-listed standards (CFR, 1996a). 


\section{DATA QUALITY OBJECTIVES WORKSHEET}

4. Waste Management

a. Listed wastes

(1) Designation as a hazardous waste - presence above detection limits with a one-to-one correlation to specific process knowledge information indicating a $>10 \%$ concentration of a specific contaminant.

(2) Disposal - concentrations above the LDR levels.

b. Characteristic wastes

(1) Concentrations above the TC levels for hazardous waste designation and for disposal.

\section{E. Identify potential sampling approaches and appropriate analytical methods}

The preferred sampling approach can be selected only after the conceptual model is formulated and the DQOs are chosen. Potential sampling approaches, from which the preferred approach may be selected, include the following:

1. Soil Borings:

- Backfill UDP with appropriate clean backfill material (approximately 7 cubic yards would be needed).

- Advance one soil boring directly through the center of the UDP.

- Continue drilling until 2 consecutive (5-foot interval), non-detect field screening readings are obtained (if above 50 feet below ground surface).

- If 2 consecutive, 5-foot-interval non-detect field screening readings are not obtained above a depth of 50 feet below ground surface, begin field screening at 10 -foot intervals and continue drilling until 2 consecutive, non-detect field screening readings are obtained or until drilling capabilities have reached maximum vertical extent.

- If contaminants are identified above field screening action levels, advance a minimum of 3 step-out borings in a roughly triangular pattern flanking the UDP at approximately 25 feet from the UDP center. Additional step-outs may be recommended to delineate the plume boundaries. Perform field screening of step-out boring samples according to the strategy described above. Advance the step-out borings to the lowest vertical extent of contamination (based on field screening readings) found in the UDP boring.

2. Field Screening: Conduct field screening on a continuous basis (starting at approximately 20 feet below ground surface) for TPH, VOCs, and radionuclides.

3. Sample Collection: Collect samples for laboratory analysis based on visual observations (e.g., areas of visible staining) and/or the results of field screening at 5-foot intervals from a depth of 20 to 50 feet below ground surface (and at 10-foot intervals below 50 feet) until 2 consecutive non-detect field screening samples are obtained. In step-out borings (if performed), collect samples from highest field-screening reading interval and lowest vertical non-detect interval. 


\section{DATA QUALITY OBJECTIVES WORKSHEET}

4. Laboratory Analysis: In the UDP center boring and in any step-out borings, submit samples for laboratory analysis obtained from the interval with the highest field screening readings and from the bottom non-detect interval. If field screening does not detect any contamination in the step-out borings, samples from these borings will not be shipped for laboratory analysis.

Proposed analytical parameters were selected based on process knowledge, the results of the 1996 waste oil characterization sampling, and analytical requirements specified by the NDEP (see Tables 3-1 and 4-1 of the CAIP). These analytical parameters include:

- Total VOCs - EPA 8260

- Total SVOCs - EPA 8270

- Total RCRA Metals - EPA 6010/7470

- PCBs - EPA 8080

- $\quad$ TPH - EPA 8015

- Nevada Test Site Waste Acceptance Criteria (NTSWAC)

An off-site, fixed-base laboratory may be used for analysis of the following soil properties:

- Initial moisture content

- Dry bulk density

- Calculated porosity

- Saturated/unsaturated hydraulic conductivity

- Particle size distribution

- Moisture retention characteristics

- Atterberg limits

5. Waste Oil Discharge Line: The connection of the line from the UDP to Building 03-60 must be verified, and the potential for leaks to have occurred from the line must also be evaluated. Confirm the location of the line using a utility line locator or air knife.

Excavate at the building footprint to uncover the pipe. If possible, locate the sump inside the building utilizing a tracer or concrete cutter. Cut the pipe at the building corner, and confirm the pipe is empty via swabbing (such as using forced air injected from the building end of the pipe toward the UDP). Possibly conduct pressure testing of the line to evaluate leak potential. If the line passes pressure test, grout line; cap both ends. If the line fails the pressure test, consider options such as shallow test pits or advancement of additional soil borings to evaluate extent and magnitude of subsurface impact. 


\section{DATA QUALITY OBJECTIVES WORKSHEET}

\section{DEFINE THE STUDY AREA BOUNDARIES}

\section{A. Define the geographic areas of the field investigation}

\section{Define the domain or geographic area within which all decisions must apply}

The Building 03-60 UDP geographic study area (CAU No. 423; CAS 03-02-002-0308) includes the UDP and waste oil line and the lateral and vertical geographic region which may have been impacted by releases of liquid from the UDP. See Attachment 1 for two-dimensional delineation of the CAU No. 423 boundaries.

2. Specify the characteristics that define the population of interest; when applicable, divide the population into appropriate sampling media or strata

The population of interest is the type, quantity, and distribution of contaminants within the Building 03-60 study area. In order to determine the type, quantity, and distribution of contaminants, four sampling media have been identified:

a. Disturbed/Construction materials -

(1) Construction materials to a depth of 20 feet below ground surface (i.e., the bottom of the UDP), including the UDP culvert (corrugated metal) and sludge.

(2) Construction materials (homogeneous gravel or leach rock) to an unknown depth below the bottom of the UDP (i.e., the most likely interval for contamination).

b. Undisturbed materials/native soils -

(1) Unsaturated native soil below the base of the UDP (less likely to be impacted due to viscosity of waste oil).

(2) Native soils lateral to the UDP which may have been impacted by contaminant migration.

c. Waste oil discharge line (and possible connections) from Building 03-60 to the UDP, as well as the surrounding soil potentially impacted by a leak from the line.

d. Groundwater (to be sampled only if an impact is suspected).

\section{Define the scale of decision making}

The scale of decision making will be based on the strata into which the site have been divided and the length of time required by ARARs. In the UDP center boring, the vertical extent of migration will be evaluated at 5-foot intervals from 20 to 50 feet below ground surface and at 10-foot intervals thereafter or until two consecutive, non-detect measurements are obtained from field screening efforts. In the step-out borings (if performed), the vertical extent of migration will be evaluated to, at a minimum, the lowest depth of contamination identified from field screening readings in the UDP center boring in accordance with the field screening and sampling strategy described previously. 


\section{B. Define the temporal boundaries of the decision}

\section{Determine the time frame to which the study data apply}

Temporal boundaries for this project include the following constraints:

a. the period of time for which the analytical data will be valid (based on the expected constituents of concern at this site, contaminant migration is anticipated to be imperceptible; therefore, the data should be valid for a significant period of time)

b. laboratory analytical holding times

c. legal deadlines such as:

(1) the time period following CAIP approval but enough prior to the CADD due date to ensure the deadline can be met

(2) finalization of the data report which will provide sufficient information to generate at CADD

d. Investigation-derived waste holding time.

\section{Determine when to collect data}

Data collection will commence following NDEP approval of the CAIP. The time frame for data collection has been tentatively established as November 9 through 21, 1997. Following data collection, the data will be compiled for generation of the final CADD due to NDEP on May 3, 1998.

Characterization activities will be conducted only during favorable weather conditions (i.e., no rain, no significant wind); however, engineering controls may be used to improve conditions. Seasonal variations are not expected to affect data quality and activities can be conducted as scheduled.

\section{Define relevant time constraints}

a. Mitigation of imminent hazards (if applicable)

b. CADD due to NDEP May 3, 1998

\section{Identify any practical constraints on data collection}

1. Testing operations (TTR security constraints)

2. Meteorological

3. Health and safety

4. Heavy equipment availability 


\section{DATA QUALITY OBJECTIVES WORKSHEET}

5. Surface and subsurface obstacles/impediments

6. Remoteness of site

7. Approval of CAIP

\section{DEVELOP A DECISION RULE - DEFINE A LOGICAL BASIS FOR CHOOSING AMONG ALTERNATIVE ACTIONS}

The decision to be made is whether the data (both historical and current) collected during the corrective action investigation process are of sufficient quality to meet the investigation objectives and to support a CADD.

\section{A. Specify the parameter that characterizes the population of interest}

The population of interest is discussed in Step IV.A.2 and consists of the type, quantity, and distribution of contaminants. The parameter used to characterize the population of interest is the analytical result from each sampling point within the UDP study area. Sampling results, when compiled for the entire study area, can then be used to evaluate the population of interest.

B. Specify the action level or preliminary action level for the decision

Action levels that trigger the Yes decisions described in Step II include:

\section{On-site field screening methods}

a. Radiation levels above twice background

b. VOC screening (25 ppm or $21 / 2$ times background [closed-bag headspace], whichever is greater; or $5 \mathrm{ppm}$ for safety in breathing zone)

c. TPH above $100 \mathrm{ppm}$

\section{Off-site analysis}

a. RCRA-listed contaminant concentrations above the NDEP Corrective Action Regulations for initial site screening and characterization and above risk-based levels

b. TPH concentrations above the TPH limits per the NAC 445A (NAC, 1996a) and NDEP Corrective Action Regulations (NDEP, 1996).

c. Presence of man-made radionuclides above background for initial gamma scan field screening, followed by application of DOE NTS/YMP RadCon Table 2.2 screening levels (i.e., 2 times background) for evaluation of laboratory analysis data, and finally risk-based analysis using RESRAD for remediation/closure evaluation. 


\section{Develop the decision rule - Combine the outputs of the previous DQO steps into "if ... then ..." decision rules that include the parameters of interest, the action levels, and the alternative actions}

\section{Contaminant Identification}

a. If the field screening and verification samples (validated laboratory analyses) do not detect contaminants, then recommend that the current study area is not contaminated (and will not be contaminated in the future) and that further assessment (at this location) is not required.

b. If the field screening and verification samples (validated laboratory analyses) detect contaminants, then further assessment (at this location) may be warranted (i.e., determine if action levels have been exceeded). If so, go to action level exceedence assessment.

\section{Action Level Exceedence}

a. If the verification samples (validated laboratory analyses) do not detect contaminants above action levels, then recommend that the current study area is not contaminated above applicable levels (and will not be contaminated further) and that further assessment (at this location) is not required.

b. If the verification samples (validated laboratory analyses) detect contaminants above action levels, then recommend that the current study area is contaminated above applicable levels and further assessment (at this location) may be warranted. If so, go to contaminant migration assessment.

\section{Contaminant Migration}

a. If the verification samples (validated laboratory analyses) do not detect contaminants above action levels beyond the boundaries, recommend that the regulated contaminant concentrations do not exceed the proposed spatial boundaries, the conceptual model does not need to be modified, and that further assessment (at this location) is not required.

b. If the verification samples (validated laboratory analyses) detect contaminants above action levels beyond the boundaries, recommend that the regulated contaminant concentrations exceed the proposed spatial boundary and the model must then be modified, and further assessment is required to evaluate the new (alternate) model. If further assessment is necessary to address migration, modeling or monitoring may be required to provide assurance over the required time. 


\section{SPECIFY ACCEPTABLE LIMITS ON DECISION ERRORS - SPECIFY DECISION ERROR LIMITS BASED ON THE CONSIDERATION OF THE CONSEQUENCES OF MAKING AN INCORRECT DECISION}

\section{A. Determine the upper and lower bounds for the parameter of interest using relevant historical site data}

The parameters of interest are the concentrations of the contaminants of concern. The upper bound is the region above the action limit where there is a very high comfort level that sample analysis results would correctly identify the sample as contaminated. The lower bound is the detection limit as specified in the laboratory Statement of Work.

B. Define both types of decision errors and identify the potential consequences of each

If the contaminated area is determined to be larger than it actually is (false positive), then more resources could be committed to the corrective action then are necessary. If the contaminated area is determined to be smaller then it actually is (false negatives), less corrective action might be undertaken than is needed to ensure protection of human health or the environment.

\section{OPTIMIZE THE DESIGN - OUTLINE A SAMPLING DESIGN, SPECIFYING THE OPERATIONAL DETAILS OF THE SAMPLING PLAN WHICH FALLS WITHIN THE PROJECTS CONSTRAINTS}

\section{A. Review the DQO outputs and existing environmental data - compile outputs from} previous steps of the DQO process

The technical approach to the completion of characterization activities will involve the following steps:

1. Locating the discharge line at the building footprint.

2. Testing the discharge line to ensure liquids are not present, to verify the connection to the UDP, to verify (if possible) that additional connections along the line are not present, and to verify that leaks are not present in the line.

3. Swabbing the discharge line, followed by plugging or capping of both ends.

4. Determining the construction of the UDP and the vertical extent of contamination directly beneath the UDP by advancing one boring through the UDP center or immediately adjacent to the UDP if advancement through the center is technically unfeasible. 
5. If contamination is detected in the UDP center boring (based on field screening results), establishing the horizontal and vertical extent of contaminant migration by advancing at least three step-out borings flanking the UDP.

6. Field screening soil samples collected from the boreholes, and collecting soil samples for laboratory analysis of parameters listed in III.A.

Complete details of this investigation approach will be described in the CAIP.

B. Develop general sampling and analysis design alternatives. For each design alternative, verify that the DQOs are satisfied

The only reasonable alternative for this investigation is the option of advancing a boring directly adjacent to the UDP as opposed to down the center of the UDP. In either case, if contamination is encountered, step-out borings will be required and the DQOs satisfied in that the lateral and vertical extent of contamination will be defined. However, by advancing a boring directly into the UDP, the level of confidence in determining the UDP configuration and the specific vertical extent of contamination in the area believed to be most highly impacted is slightly higher than with the design alternative.

\section{Select the most resource-effective design that satisfies all of the DQOs}

The most resource-effective design that satisfies all of the DQOs is to advance one boring directly through the center of the UDP, advance step-out borings as needed to bound the lateral and vertical extent of contamination, and collect samples for laboratory analysis as outlined in Step III.E.

D. Document the operational details and theoretical assumptions of the selected design in the sampling and analysis plan

Detailed documentation of sampling and analysis operations will be contained in the Corrective Action Investigation Plan and associated field instructions and operating procedures. 
CAIP CAU No. 423

Attachment 1

Revision: 0

Date: 10/27/97

Page A-19 of A-38

\section{Attachment 1}

\section{Building 03-60 Site Map and Aerial Photograph}




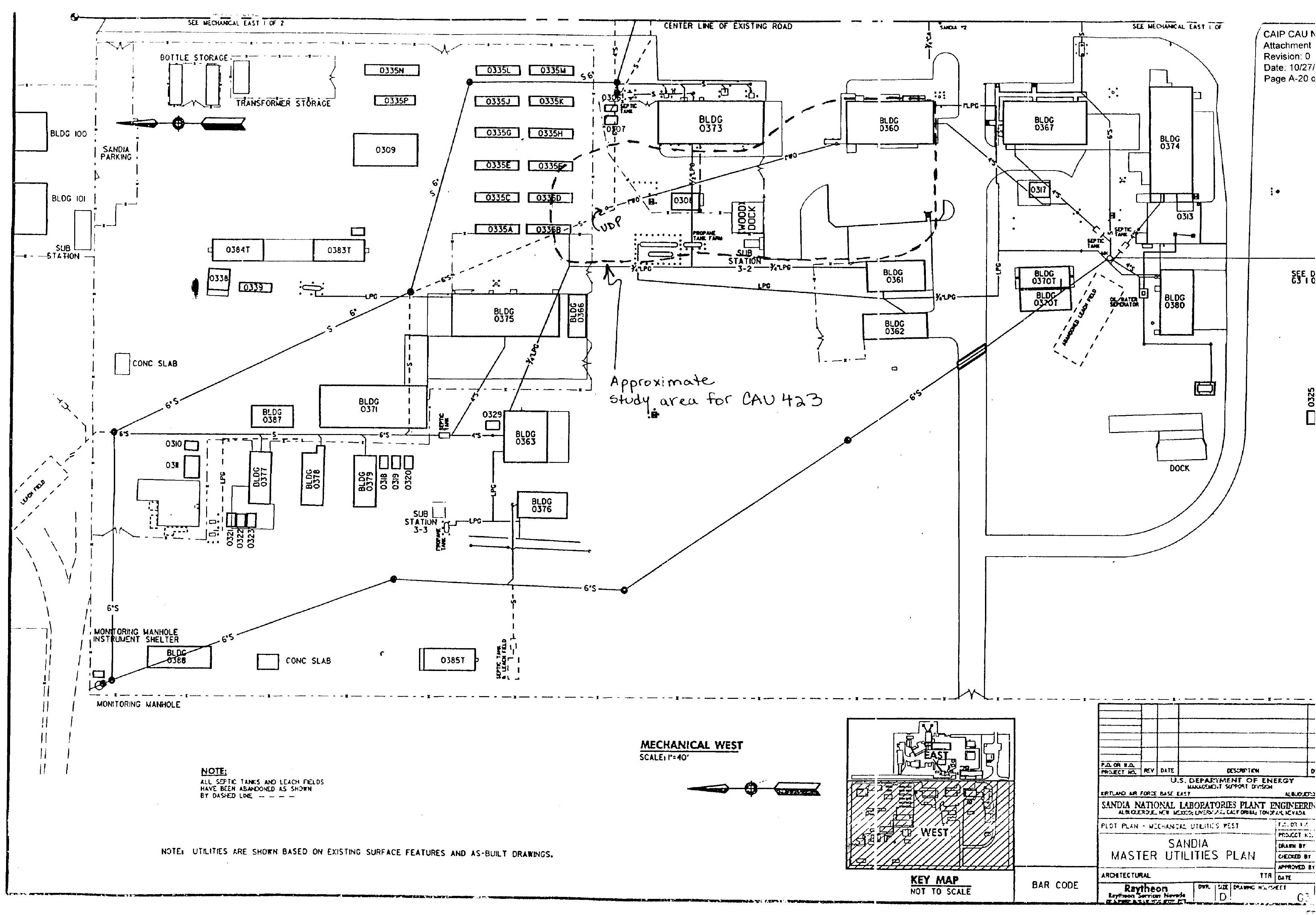




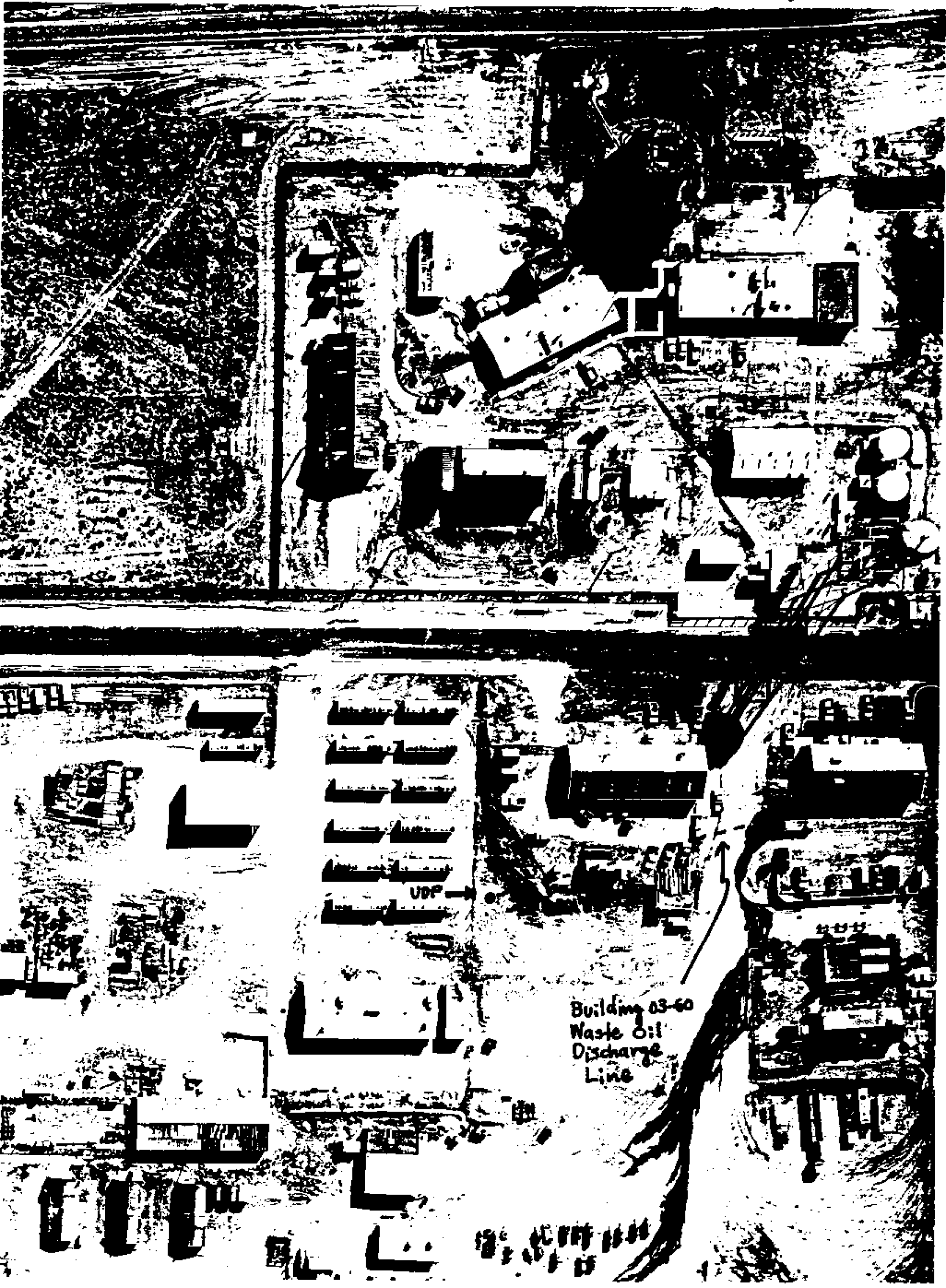




\section{Attachment 2}

\section{Building 03-60 UDP Photographs}




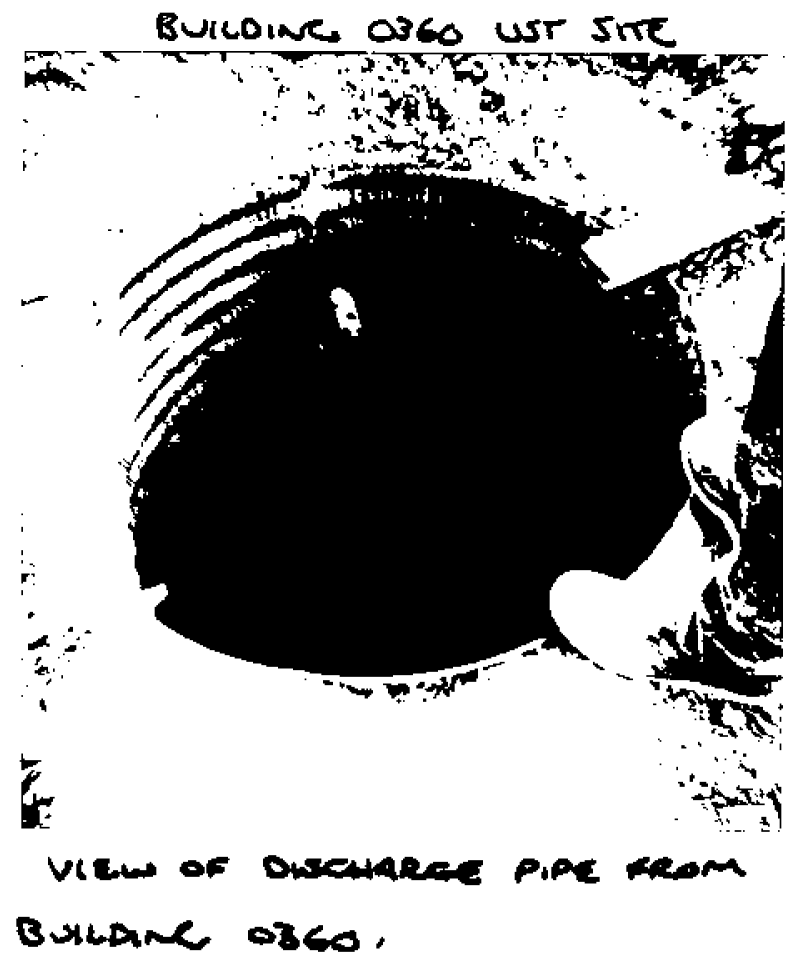

BUILDINC O36O UST SITE

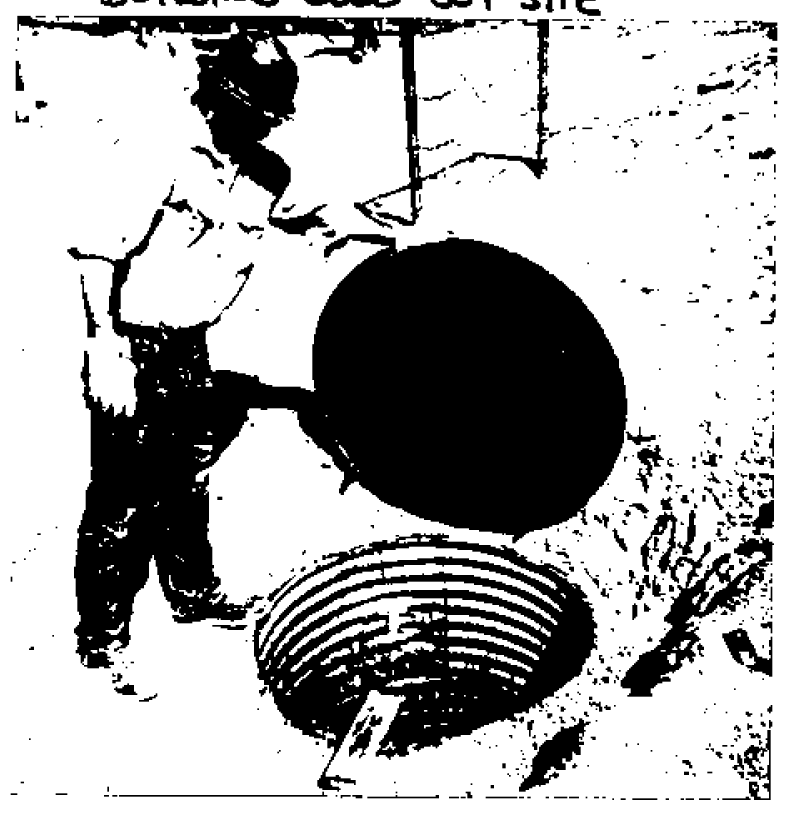

vicus of cantworks Ppe with

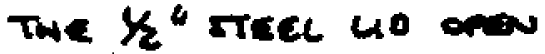

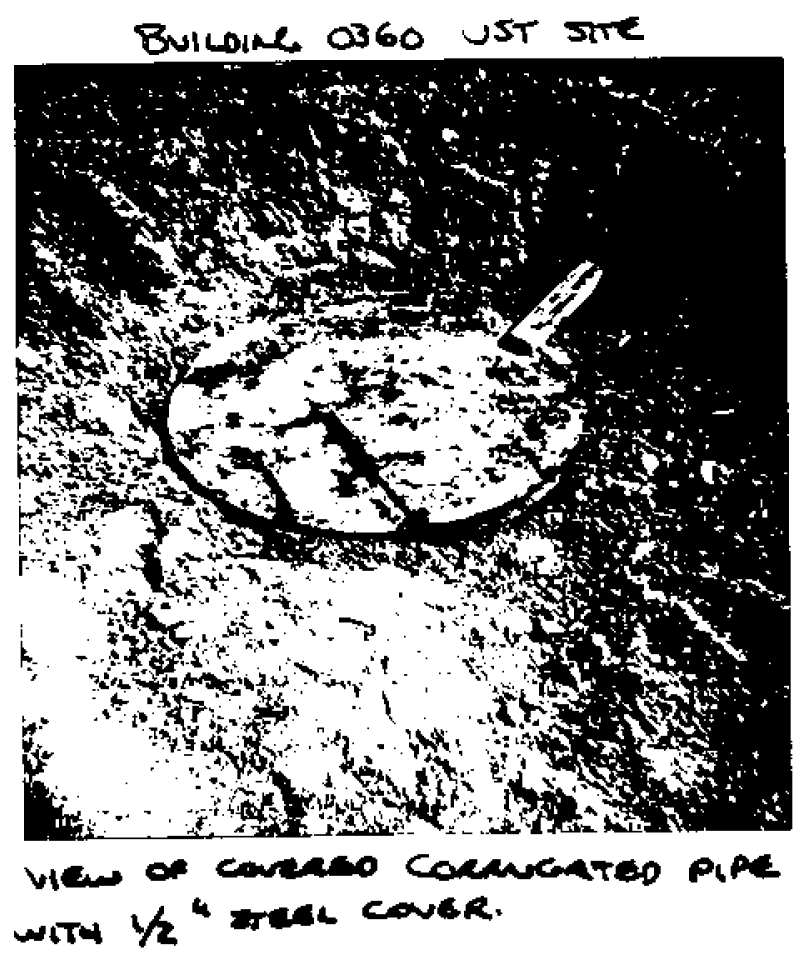

BUILOING ONGO UST STE

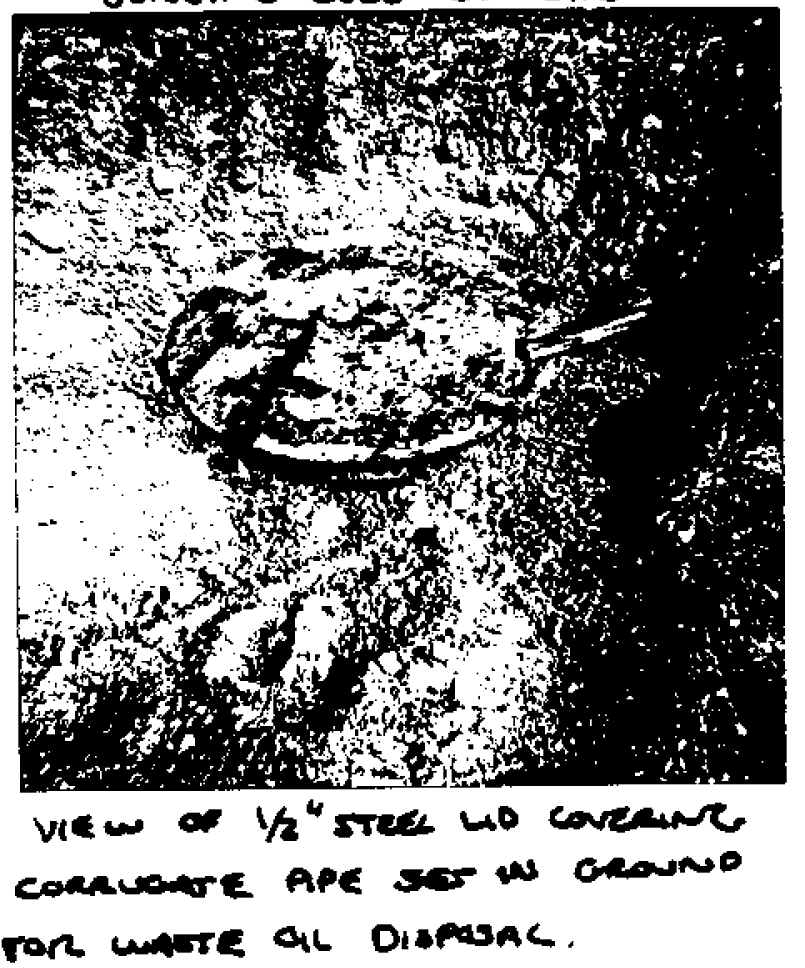




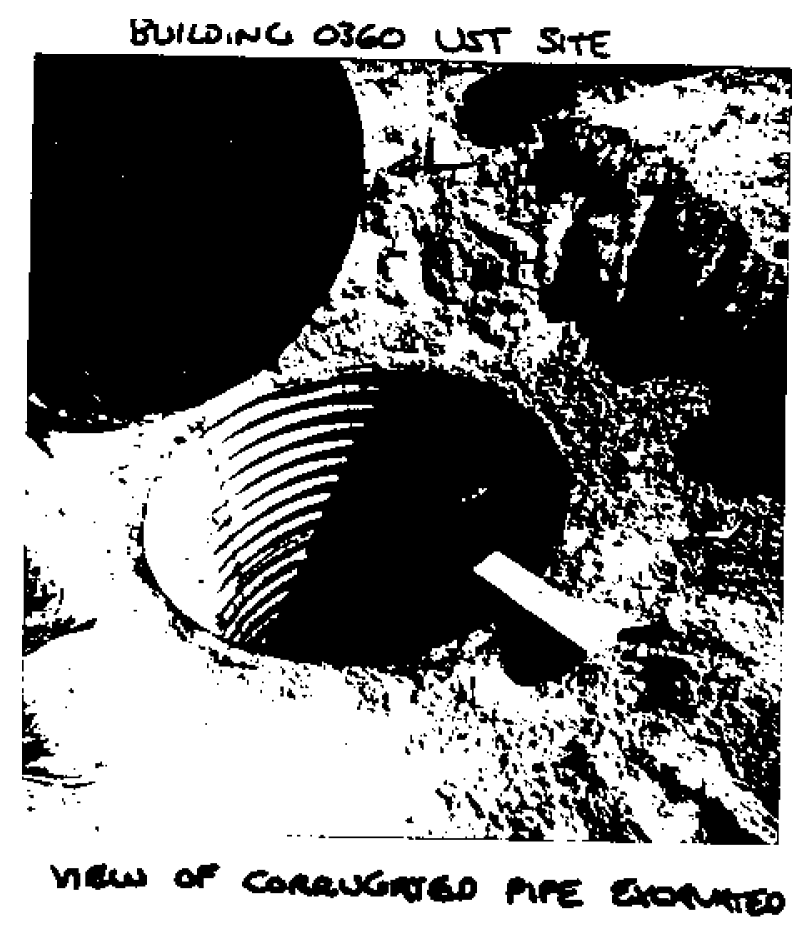

BUIDINE 0360 UST ITE

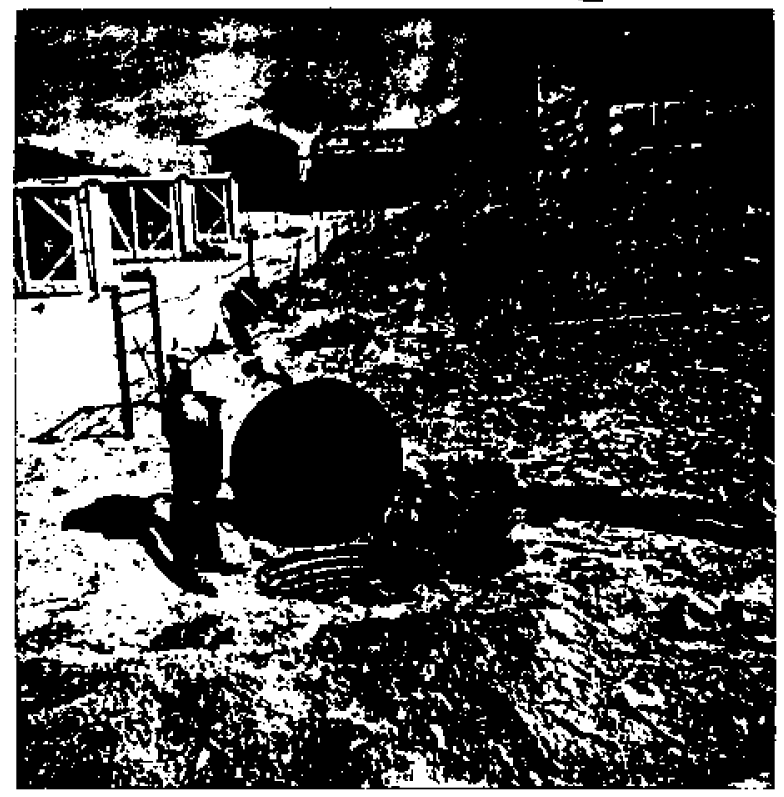

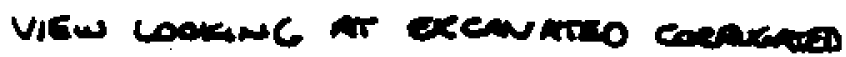
Pife with Twe lio opin,

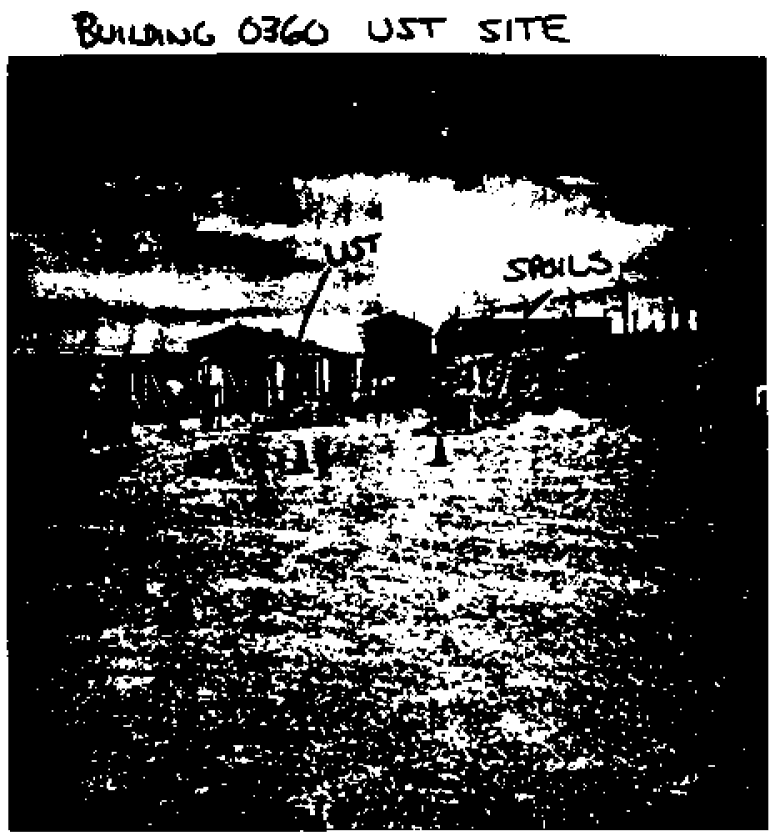

view of Exclusion ZoNe

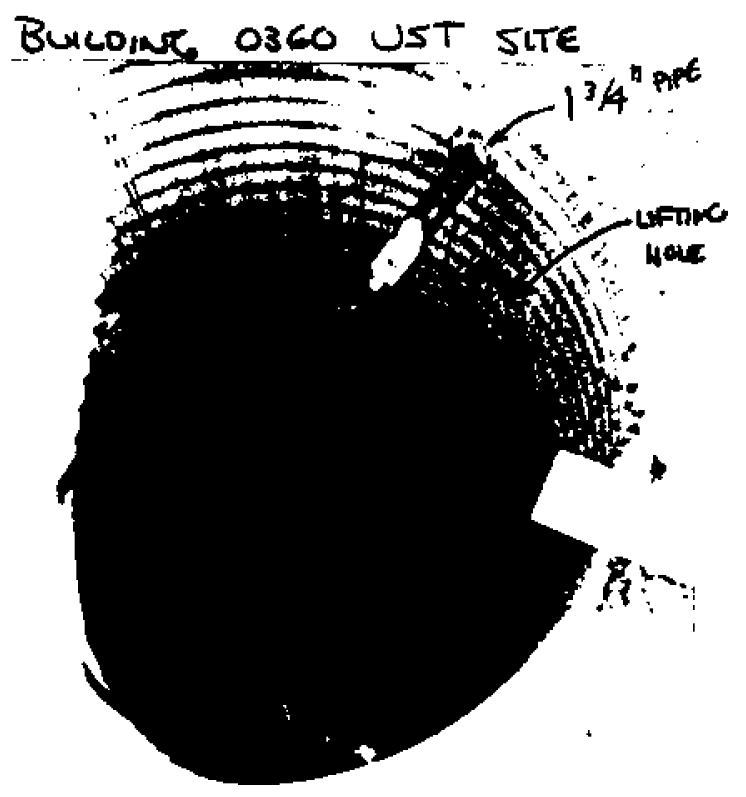

Vifu cookere bowal into the

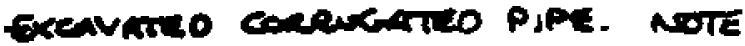
Refletion on surface of OIL. 
Revision: 0

Date: $10 / 27 / 97$

Page A-25 of A-38

\section{Attachment 3}

\section{Building 03-60 UDP Waste Oil Sampling Results}


Detected Analytes for Building 03-60 UDP Fluid Sample TTR00023

\begin{tabular}{|c|c|c|c|c|}
\hline Analysis & Method & Compounds & $\begin{array}{c}\mathrm{MDL} \\
(\mu \mathrm{g} / \mathrm{mL})^{\mathrm{b}} \\
\end{array}$ & $\begin{array}{c}\begin{array}{c}\text { Concentration } \\
(\mu \mathrm{g} / \mathrm{mL})\end{array} \\
\end{array}$ \\
\hline Total VOA & SW-846-8260 & Benzene & 13 & 18 \\
\hline Total VOA & SW-846-8260 & n-Butylbenzene & 13 & 458 \\
\hline Total VOA & SW-846-8260 & sec-Butylbenzene & 13 & 51 \\
\hline Total VOA & SW-846-8260 & 2-Chlorotoluene & 13 & 763 \\
\hline Total VOA & SW-846-8260 & 4-Chlorotoluene & 13 & 45 \\
\hline Total VOA & SW-846-8260 & 1,2-Dichlorobenzene & 13 & 70 \\
\hline Total VOA & SW-846-8260 & 1,3-Dichlorobenzene & 13 & 26 \\
\hline Total VOA & SW-846-8260 & 1,4-Dichlorobenzene & 13 & 29 \\
\hline Total VOA & SW-846-8260 & Ethylbenzene & 13 & 172 \\
\hline Total VOA & SW-846-8260 & Isopropylbenzene & 13 & 40 \\
\hline Total VOA & SW-846-8260 & p-Isopropyltoluene & 13 & 79 \\
\hline Total VOA & SW-846-8260 & Naphthalene & 13 & 361 \\
\hline Total VOA & SW-846-8260 & Toluene & 13 & 269 \\
\hline Total VOA & SW-846-8260 & $\begin{array}{l}1,2,4- \\
\text { Trimethylbenzene }\end{array}$ & 13 & 620 \\
\hline Total VOA & SW-846-8260 & $\begin{array}{l}1,3,5- \\
\text { Trimethylbenzene }\end{array}$ & 13 & 322 \\
\hline Total VOA & SW-846-8260 & Total Xylenes & 13 & 948 \\
\hline Total SVOA & SW-846-8270/625 & Naphthalene & 200,000 & 339,000 \\
\hline Total SVOA & SW-846-8270/625 & 2-Methylnaphthalene & 200,000 & 493,000 \\
\hline Total SVOA & SW-846-8270/625 & $\begin{array}{l}\text { 2-\&/or 3- } \\
\text { Methylphenol }\end{array}$ & 200,000 & 291,000 \\
\hline Analysis & Method & Compound & $\begin{array}{c}\text { Results } \\
(\mathrm{mg} / \mathbf{L})^{\mathrm{e}}\end{array}$ & - \\
\hline TCLP ${ }^{\mathrm{f}}$ Metals & SW-846-1311/6010 & Lead (TCLP) & 1.17 & \\
\hline TCLP Metals & SW-846-1311/6010 & Arsenic (TCLP) & $<0.08$ & \\
\hline
\end{tabular}




\begin{tabular}{||l||l|l|c|c||}
\hline TCLP Metals & SW-846-1311/6010 & Barium (TCLP) & 0.04 & \\
\hline TCLP Metals & SW-846-1311/6010 & Cadmium (TCLP) & $<0.02$ & \\
\hline TCLP Metals & SW-846-1311/6010 & Selenium (TCLP) & $<0.20$ & \\
\hline TCLP Metals & SW-846-1311/6010 & Chromium (TCLP) & $<0.03$ & \\
\hline TCLP Metals & SW-846-1311/6010 & Silver (TCLP) & $<0.01$ & \\
\hline TCLP Metals & SW-846-1311/7470 & Mercury (TCLP) & $<0.001$ & \\
\hline Flashpoint & SW-846-1010 & & $>230{ }^{\circ} \mathrm{F}$ & \\
\hline \hline Analysis & Method & Parameter & Result & MDA \\
$(\mathbf{p C i} / \mathbf{L})^{\mathrm{g}}$ & $(\mathbf{p C i} / \mathbf{L})^{\mathrm{b}}$ \\
\hline \hline Gamma Spec. & HASL 300,4.5.2.3 & Cesium-137 & ND & 13.2 \\
\hline Gamma Spec. & HASL 300,4.5.2.3 & Potassium-40 & 248 & 137 \\
\hline Gamma Spec. & HASL 300,4.5.2.3 & Lead-212 & 17.4 & 14.4 \\
\hline \hline
\end{tabular}

Method Detection Limit

'Micrograms per milliliter

"Volatile Organic Analysis

'Semuvolatile Organic Analysis

'Milligrams per Liter

Toxicity Characteristic Leaching Ptocedure

Picocuries per Liter

Minimum Detectable Activity

'Environmental Methods Laboratory Procedure Manual, HASL-300 (U.S. DOE)

Not Detected 
Revision: 0

Date: 10/27/97

Page A-28 of A-38

\section{Attachment 4}

\section{CAU No. 423 Waste Determination}


July 2, 1996

Project No.: 764038.02010100

Mr. Kevin Cabble

U.S. Department of Energy

Nevada Operation Office

P.O. Box 98518

Las Vegas, Nevada 89193-8518

Contract No. DE-AC08-92NV 10972

Records For Hazardous Waste Identification of Building 0360 Waste Oil Underground Discharge Point

Dear Mr. Cabble:

Enclosed are the records used to make a hazardous waste determination for the liquid waste contained in the Building 0360 Underground Discharge Point (UDP) located in Area 3, at the Tonopah Test Range (TTR). Please transmit a copy of this Record to the Nevada Division of Environmental Protection (NDEP) for Karen Beckley's review and concurrence.

If you have any questions or comments, please call me at 4-1539.

Sincerely.

TT corporation

Richard A. Dubiskas

Technical Lead

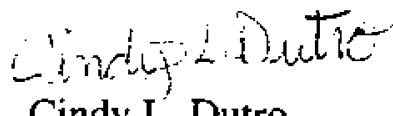

Cindy L. Dutro

Regulatory Analyst

C: P. A Sanders DOE/EPD (with enclosure)

Enclosure 


\section{RECORDS FOR HAZARDOUS WASTE IDENTIEICATION QE BUILDING 0360 WASTE OIL UNDERGROUND DISCHARGE POINT}

\section{Introduction}

Building 0360 is located at the Tonopah Test Range (TTR) in Area 3 an Under Ground Discharge (UDP) was discovered at this location. The UDP was previously incorrectly identified as an Underground Storage Tank (UST) in a geophysics survey. An Environmental Protection Agency (EPA) Form 7530-1, Notification for Underground Storage Tanks was submitted to the Nevada Division of Environmental Protection (NDEP) on January 25, 1996. Subsequent investigation activities showed that a UDP existed, not a UST. An amended EPA Form 7530-1, Notification for Underground Storage Tanks will be submitted to NDEP.

\section{Overview of Historical Knowledge}

Building 0360 is used as a Light Duty Fleet Shop that for an undetermined period discharged waste oil to the UDP. The UDP is adjacent to a barbed-wire fence near the south end of the boxcar storage yard at Area 3. This location is approximately 150 feet northwest of Building 0360. The location of the UDP is shown in the Site Map (Attachment 1). No records were found that showed the amount of waste oil that was discharged to the UDP. Currently, waste oil generated at the Light Duty Fleet Shop is containerized and delivered to the United States Air Force (USAF) for disposal.

The UDP is approximately 20 feet deep and 42 inches in diameter; the liquid contained in the UDP is estimated to be approximately 400 gallons. Samples were collected and sent to SouthEastern Analytical Services, Incorporated (SEAS), for analyses as reported in (Attachment 2). The UDP contains waste oil, volatile organic compounds, aromatics, and chlorinated aromatics.

\section{Hazardous Waste Identification}

A review of the laboratory analysis was conducted in accordance with 40 CFR 261.2 requirements to determine if the waste contained in the UDP met the definition of a solid waste. It was determined that the contents of the UDP met the definition of a solid waste. Next, 40 CFR 261.3(a)(2)(iv), 261.4, and 261.6(a)(3) were reviewed to determine if the waste was excluded from regulation as a solid waste or hazardous waste. It was determined that the waste was not excluded from regulation as a solid or hazardous waste. Then a review of 40 CFR 261.11, $261.30,261.32$, and 261.33 was conducted to determine if the waste was a "listed waste." It was determined that the waste liquid contained an "F002" listed waste in the form of orthodichlorobenzene.

The State of Nevada's position has typically been that if there is no demonstrated evidence that a waste is "listed" (such as documentation showing that spent solvents would be likely to be present due to historic operations), that the waste should be considered to be "characteristic" rather than "listed." It is not assumed that a waste is "listed" just because a given constituent is detected. 
Therefore, it was necessary to review historical records for Building 0360 to determine if orthodiclorbenzene was an ingredient in any product in excess of $10 \%$ or more by volume of the original product (the amount necessary to make the waste an "F002" waste). Records reviewed included Chemical Inventories, and Preliminary Hazard Assessment for Building 0360 (Attachment 3). Material Safety Data Sheets (MSDSs) were obtained for products on the Chemical Inventories for Building 0360. Upon receipt, the MSDSs were reviewed to determine if any products contained ortho-dichlorobenzene as an ingredient. None of the MSDSs identified its use in the product formulation.

The next step was a review of the Uniform Hazardous Waste Manifests (Attachment 4) for Building 0360 to determine if an "F002" waste was shipped from Building 0360. This review identified that an "F002" waste was collected from Building 0360 by Safety-Kleen Corporation from 1988 through 1990 under a contract with Sandia National Laboratory.

Safety-Kleen Corporation's Las Vegas Office was contacted and a request was made for MSDSs for all products that Safety-Kleen Corporation supplied for use in Safety-Kleen Corporation's parts washers that were located in Building 0360. Safety-Kleen Corporation reviewed their records and provided MSDSs for "Immersion Cleaner and Cold Parts Cleaner" and "Safety-Kleen 105 Solvent" (Attachment 5) the MSDSs were reviewed and they did not identify orthodichlorobenzene as part of the products formulation.

After this review, Safety-Kleen Corporation's Product Development Center was contacted and asked whether Safety-Kleen products used in Building 0360 were reformulated or was an administrative error made on the manifest (i.e., the waste should not have been shipped as an "F002" waste). Safety-Kleen supplied the formulation history for "Immersion Cleaner and Cold Parts Cleaner" and the MSDS issued in 1989 (Attachment 6). These records show that the product contained more than $10 \%$ by volume of ortho-dichlorobenzene at the time of its use in Building 0360. Therefore, the waste contained in the UDP will be managed as an "F002" "listed" waste.

The liquid from the UDP will be pumped and transported to a permitted treatment, storage, or disposal (or recycling) facility. The NDEP will be notified prior to the waste being transported from TTR to a permitted facility. 
Attachment 3

pate: uetober 24,1990

To: Distribution

From: L.M. Christie 7513

Attached are printouts of the Chemicol Inventory for your Droanization and bulldinge.

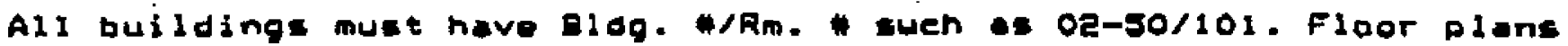
aro provided far roference. Qutlylng trailer tuch as 51-01/871 and 39-01/6s are good locations.

Se baek of Manual Entry Form for the following..

1. Maximun Guantity ls numeric velue representing the total ameunt present in a gingla loeation. ses 1 tom 4 .

2. Buentity Jnit mugt be as otated in 1 tem

3. Physlcal state must bo as stated in 1 tem 10.

4. Storage Code mutt be 3 digit code, sea chart.

Forms for additions and doletiono are avaliable upon requett.

Please return your corrocted eopins to L. Christie, 7511 Defore Novemoer eO, 1990 .

Distr $\$$ bution:

7511 R.R. Bester

7512 1.C. Alemander

7513 G.L. West

7524 C.E. Smith

Reoco. B.C. MeNoll1

ASI P.T. MoreY 
JUN 19 '95 01:22PM ER\&TDD/ERS A-23

ORO, BLDG./ROOH PRODUCT

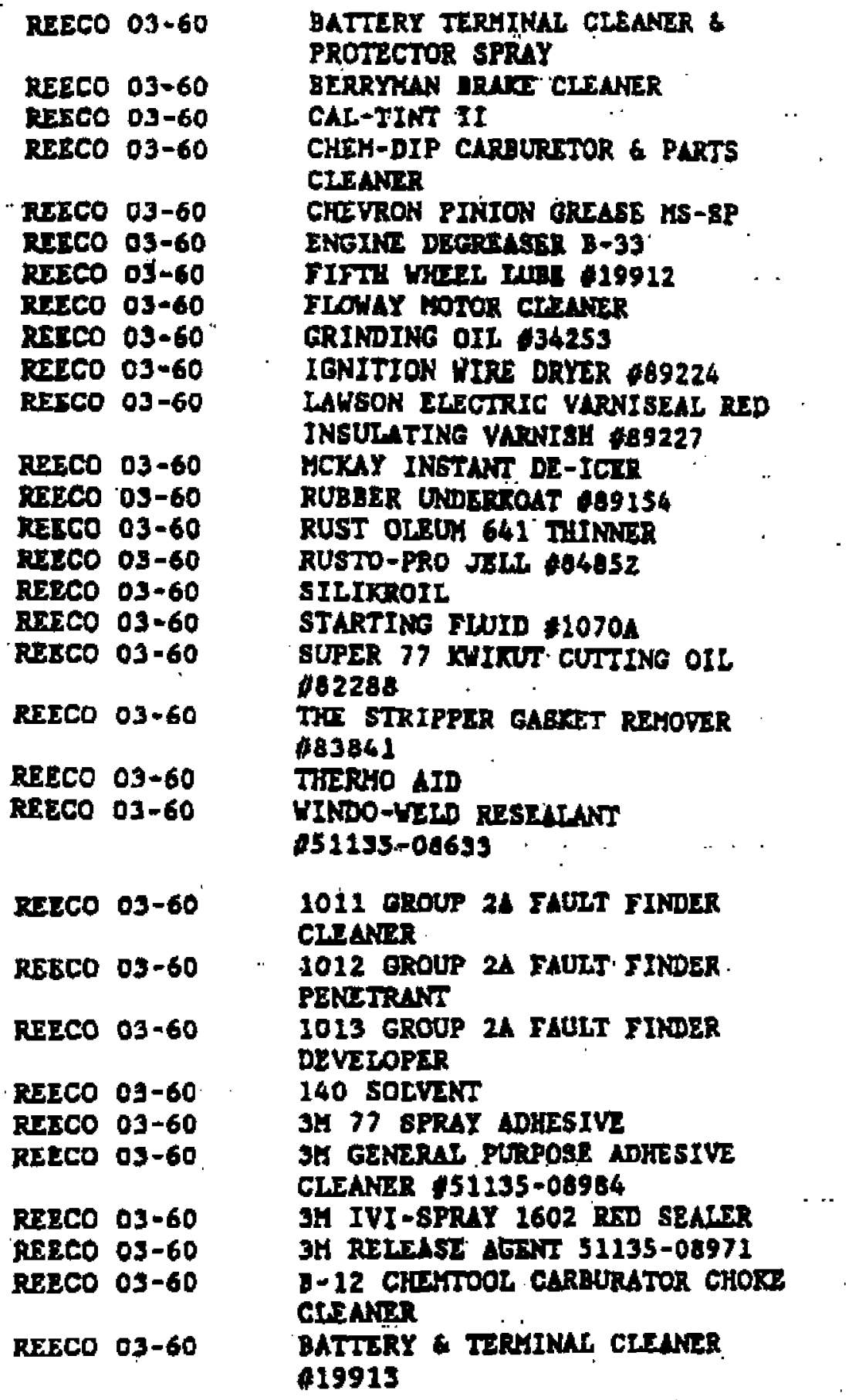

CAIP CAU No. 423

Attachment 4

Revision: 0

Date: $10 / 27 / 97$

Page $\mathrm{A}-33$ of $\mathrm{A}-3 \mathrm{~B}$ P., 3

HAX. QUANT. STOR EHTS. MANUFACTURER CODE ITAT:

\begin{tabular}{|c|c|c|c|c|}
\hline 13.0 & (ozd) & & $\mathbf{s}$ & MCXAY MTG. Co. \\
\hline $\begin{array}{r}22.0 \\
16.0 \\
5.0\end{array}$ & $\begin{array}{l}(\text { ozd }) \\
(\text { azd }) \\
(\mathbf{g a d})\end{array}$ & 724 & $\begin{array}{l}L \\
L \\
L\end{array}$ & $\begin{array}{l}\text { BERRYMA PRODUC } \\
\text { NO DEX INC. } \\
\text { BERRYAAK PRODUC }\end{array}$ \\
\hline $\begin{array}{l}13.0 \\
16.0 \\
14.0 \\
1.0 \\
1.0 \\
24.7 \\
12.7\end{array}$ & 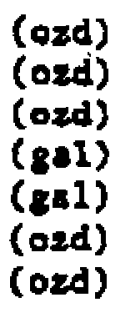 & $\ldots$ & $\begin{array}{l}\mathbf{s} \\
\mathbf{s} \\
\mathbf{5} \\
\mathrm{L} \\
\mathrm{L} \\
\mathrm{s}\end{array}$ & $\begin{array}{l}\text { CHEVRON USA } \\
\text { DERRYAN } \\
\text { LAUSON PRODUCT } \\
\text { TANO IABORATORI } \\
\text { BLACX \& DRCRER } \\
\text { LAYSON PRODUCTS } \\
\text { LAWSON PRODUCTS }\end{array}$ \\
\hline $\begin{array}{r}0.0 \\
17.7 \\
1.0 \\
7.0 \\
1.0 \\
11.0 \\
0.0\end{array}$ & $\begin{array}{l}\text { (ozd) } \\
(\text { zad) } \\
(\text { ozd) } \\
(\text { zad }) \\
(\text { ozd) } \\
(1)\end{array}$ & 514 & $\begin{array}{l}\mathbf{S} \\
\mathrm{L} \\
\mathbf{L} \\
\mathrm{L} \cdot \cdot \\
\mathbf{\delta}\end{array}$ & $\begin{array}{l}\text { IAWSON PRODUCTE } \\
\text { ROST OLRUM CORP } \\
\text { LAWSON PRODUCTS } \\
\text {-KANO LABORATORI } \\
\text { LOCTITE CORP } \\
\text { LAHSON PRODUCTE }\end{array}$ \\
\hline .0 & & & $\mathbf{s}^{\cdots \cdots}$ & LAYSON PRODUCTE \\
\hline $\begin{array}{l}5.0 \\
1.0\end{array}$ & & & $\begin{array}{l}I \\
I\end{array}$ & $\begin{array}{l}\text { NAPA } \\
3 M\end{array}$ \\
\hline
\end{tabular}

12.0 (ozd) 724 I GROAN InDUSTRLA 22.0 (ozd) $\mathrm{MA} t$ CRONN INDUSTRIA 12.0 (ozd) 524 L . CROTN INDUSTRIA 1.0 (dx) 17.0 (ozd) $724 \quad$ L $\quad 34$ 1.0 (qt) $\mathrm{L} \quad 3 \mathrm{H}$

13,0 (ozd) S $3 \mathrm{H}$ 18.2 (ood) "E 13.0 (osd) s BERRMAN PRODUC 13.7 (oxd) is LAWSON PRODUCTS. 


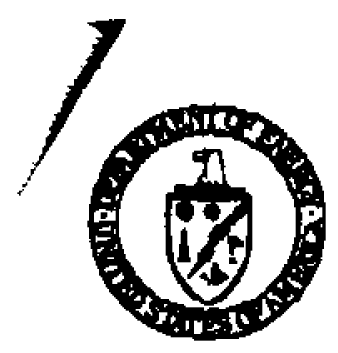

Peul. J. Liebendorfer, P.E. Chief

Bureau of Federal Faoilities

Nevada Division of Environmental Protection

State of Nevade

$333 \mathrm{~W}$. Nye Lane

Carson City, NV 89710

\section{SUBMTTTAL OF RECORDS FOR HAZARDOUS WASTE IDENTIFICATION OF BULDNG 0360 WASTE OIL UNDERGROUND DISCHARGE PORT, TONOPAH TEST}

IT Corporation has completed a record search for hazardous waste identification of the Area 3 , Building 0360 Underground Discharge Point (UDP), Corrective Action Unit 406, Corrective Action Site 03-02-002-03-008 at the Tonopah Test Range. Enclosed for your review and concurrence are the records used to make a hazardous waste determination for the liquid waste in
the UDP.

The next phase of this project will be to pump out the free liquids from the UDP. This activity is planned for the week of July 22-25, 1996. If you have any questions regarding this activity, please contact Kevin J, Cabble, of my staff, at
(702) $295-5000$.

ERD:KJC

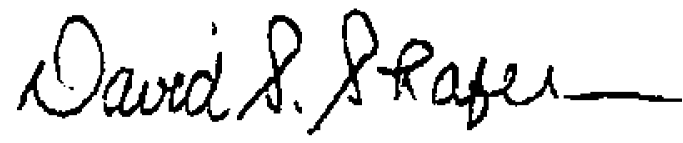

David S. Shafer, Acting Director Environmentu Restoration Division

Encloyures:

As stated

ce w/o erscls:

K. K Beckley, NDEP, Carson City, NV

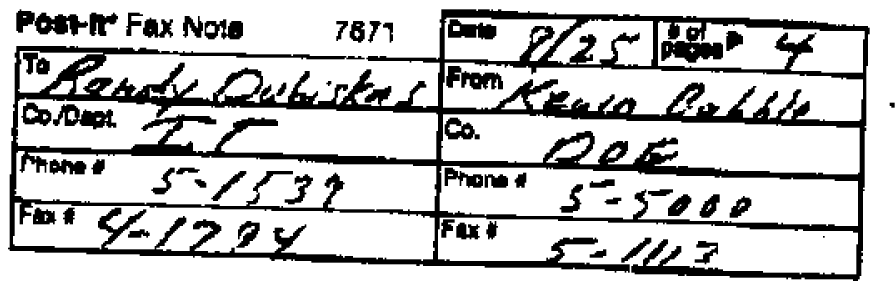




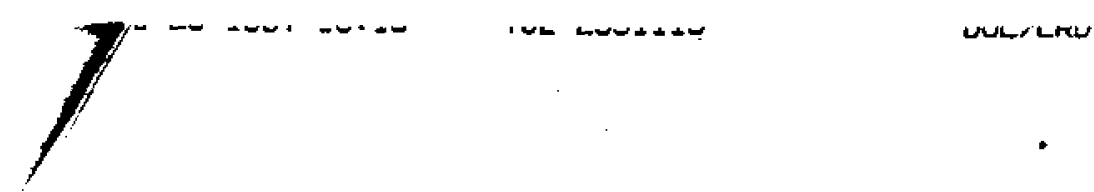

Paul. J. Liebendorfer
$-2$.
CAIP CAU No. 423

Attachment 4

Revision; 0

Date: $10 / 27 / 97$

Page A-35 of A-3B

bee w/o encl:

K. C. Besch, IT, Las Vegas, NV

R. A. Dubisices, IT, Lu Vegas, NV

D. S. Shafer, ERD, DOE NV, Las Vegaa, NV

K. J. Cabble, ERD, DOE/NV, Laa Vegas, NV

S. T. Curtis, ERD, DOE/NV, Lae Vegar, NV

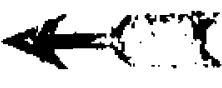

J. N. Romo, ERD, DOE/NV, Lu, Vegas, NV 
CAIP CAU No. 423

Attachment 5

Revision: 0

Date: $10 / 27 / 97$

Page A-36 of A-38

\section{Attachment 5}

\section{Uniform Hazardous Waste Manifests}


Please orini or cyod (Furm dosigned tor use on elite [ 12 -prich) lypewriler-)

\section{A. UNIFORM HAZARDOUS
WASTE MANIFEST}

3. Genera1or's Name and Mailing Address

U.S. Department of Energy/Nevada Operations Office/ERD

P.0. Box 98518, Las Vegas, NV 89109 Attn. David Shafer

4. Generator's Phone $702,295-0542$

\begin{tabular}{|lcl|l} 
5. Transponer. 1 Company Name & 6. & US EPA ID Number & C. Stale Transporter's ID
\end{tabular}

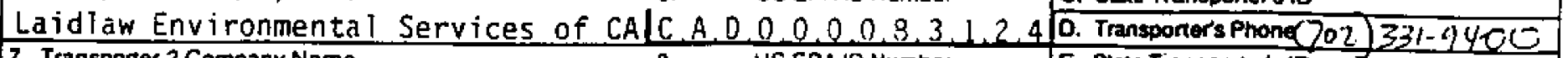

\begin{tabular}{|l|l|l|l|}
\hline 7.. Transporter 2 Company Name & 8. & US EPA ID Number & E. State Transporter's ID \\
\cline { 3 - 4 } & & & F. Transponor's Phone \\
\hline 9.
\end{tabular}

9. Designaled Facility Name and Site Address

10. US EPA ID Number

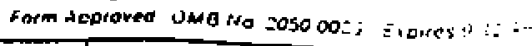

Laidlaw Environmental Services S.W.

1340 W. Lincoln Street

Phoen ix, AZ 85007

IA

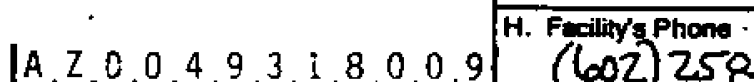

A. Slate Manilost Document Number:

B. State Generator's ID

G. State Facility/s ID

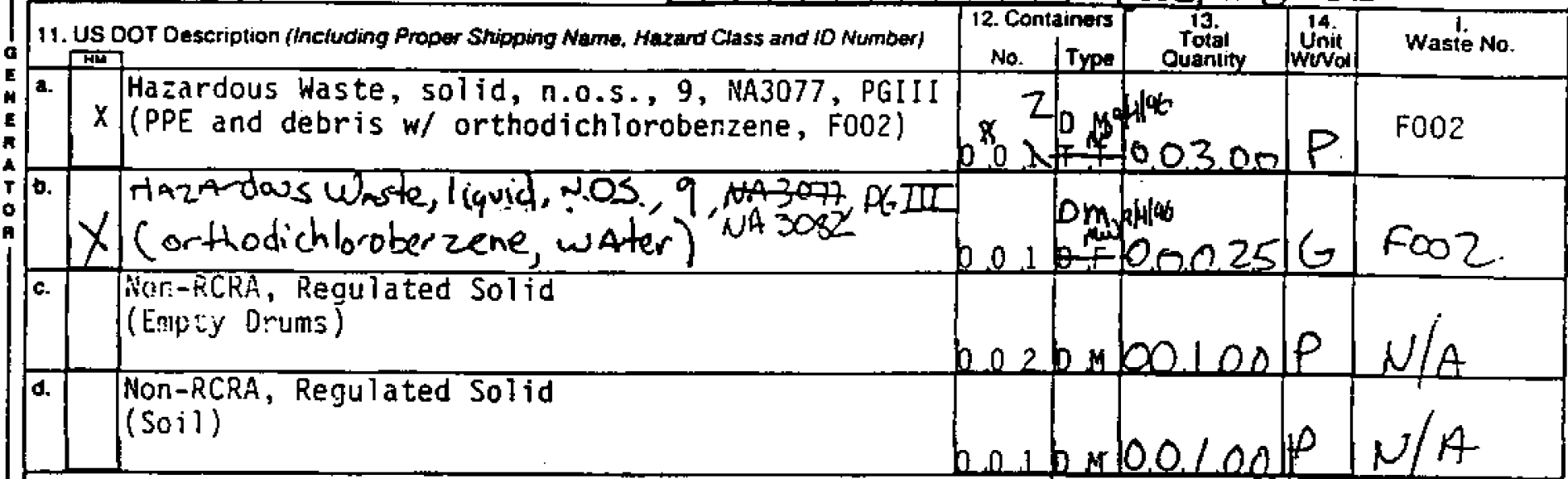

J. Additional Descriptions for Materials Lusted Above

K. Handling Codes tor Wastes Listed Above

15. Special Handling instructions and Additional information

ERG\# 171 Emergency Contact: (702) 295-6400

Approvais lia) NVDPEOOO1 11b)WPPECOE2 11c) NVOP0004 11d)NVDPE0003

Certificate of Disposal Requested

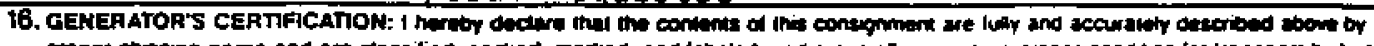

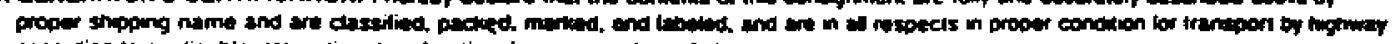

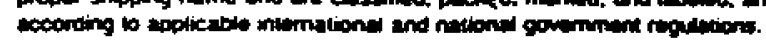

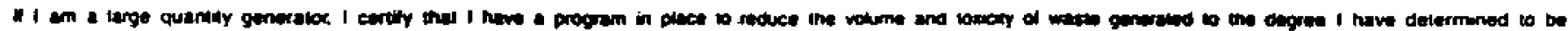

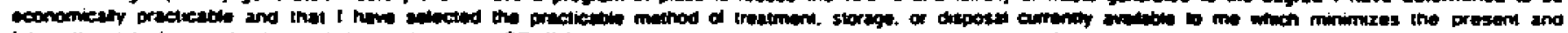

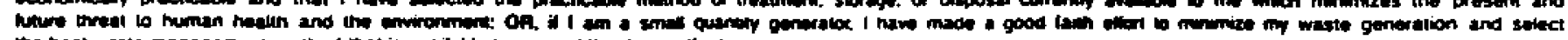

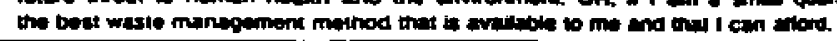

Printed/Typed Name

Matthew Wilson for DOE/NV/ERD

T 17. Transporter 1 Acknowledgement of Receipl of Materials 17. Transporter 1 Acknowied

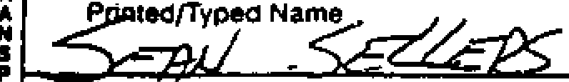

16. Transporter 2 Acknowedgement ol Receipt of Materials

Printed/Typed Name

19. Oiscrepancy Indication Space

E.

20. Facitity Owner or Operator: Certification of receipt of hazardous materials covered by ths manilest except as noted in ftem 19 .

Printed/Typed Name 50 colleber

Signguve 7330 Month Day Yas

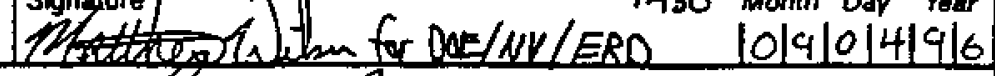

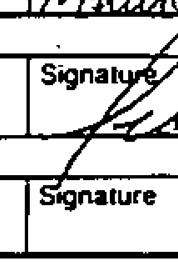

Month Dar Yer Month Day

Month Day rear

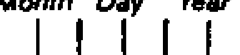




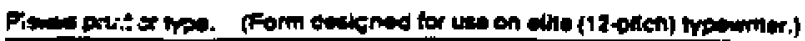

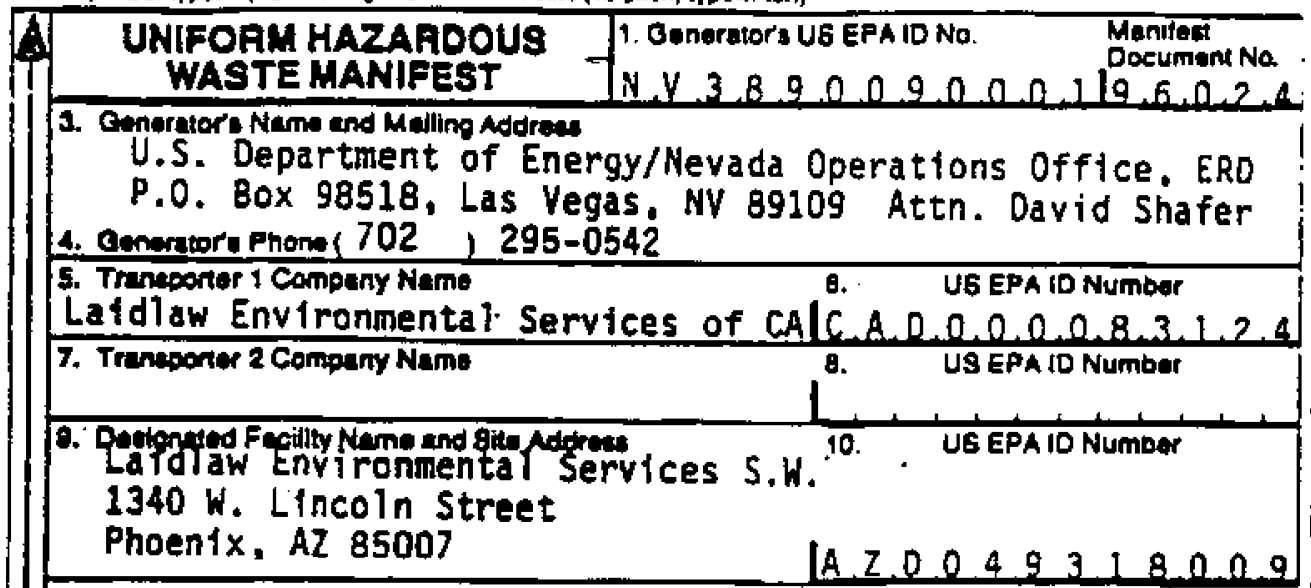

CAIP CAU No. 423

Attachment 5

Revision: 0

Date: $10 / 27 / 97$

Page A-38 of A-38

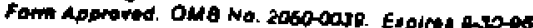

2. Peos 1 Intormation in the andedod areas le not required by Federa law.

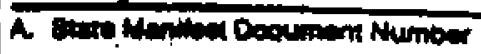

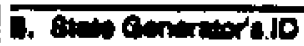

C. Bute Trampoted is

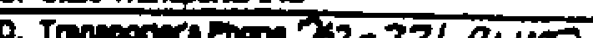

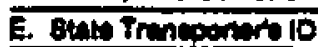

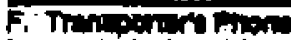

c. Gua Fraing io

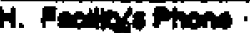

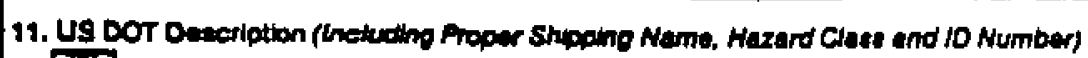
arin

a. $x$ Hazardous Waste, Liquid, n.0.5.,9, NA3082, PGI If

$\mathbf{4}$

b.

$x$ (Ofi contaminated $w /$ orthodichiorobenzene, F002)

a.

a

a.

12. Contai ion

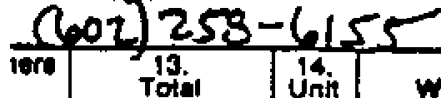

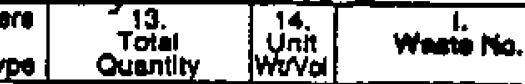
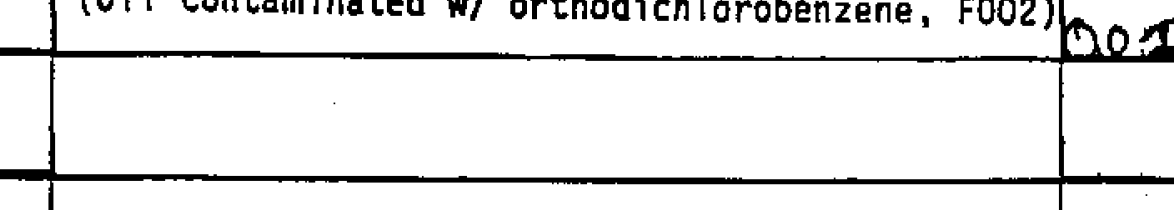

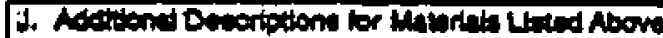

i. Hendiling Coded for Wente Ltrad Above

15. Bpecial Handting Inatructors and Addwoned Information
ERG 1: 171
Energency Contact:
(702) 295-6400

Approval 11a) NVDPEO0O2

Swo 25001

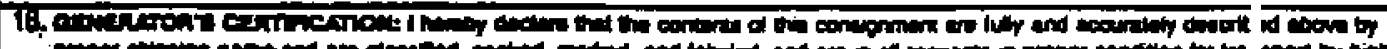

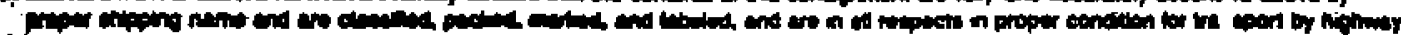

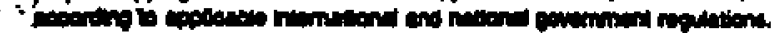

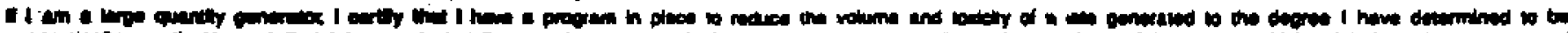

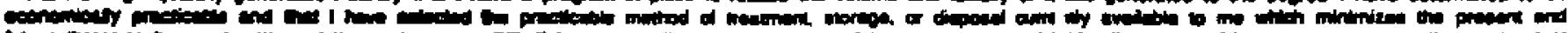

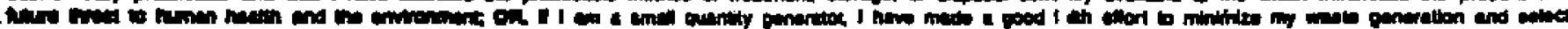

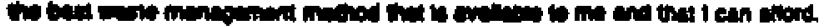

Pritiodryped Neme Hatthew Hilson for DOE/NW/ERO

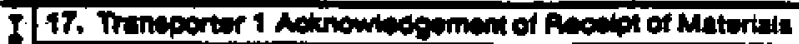

\begin{tabular}{|c|c|}
\hline 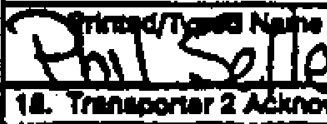 & 8 \\
\hline Prisdired Hem & Eloneturo \\
\hline
\end{tabular}

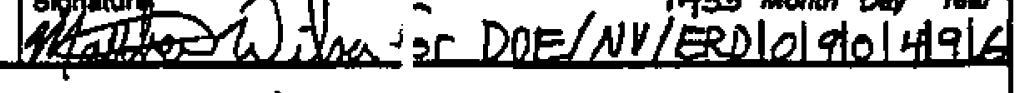

11. Disoruparoy indiection spaces

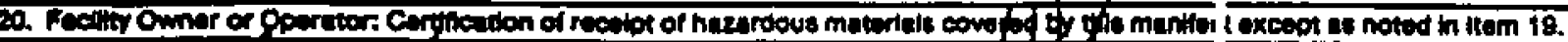
Priniedriped $\mathrm{N} / \mathrm{m}$ cougref

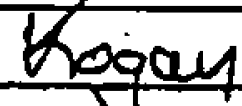

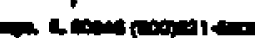

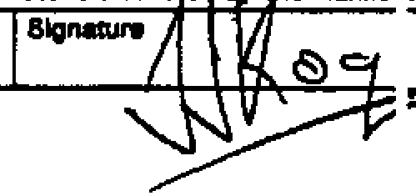


Revision: 0

Date: $10 / 27 / 97$

Page B-1 of B-3

\section{Appendix B}

\section{NDEP Document Review Sheet for Draft CAIP}




\section{NEVADA ENVIRONMENTAL RESTORATION PROJECT DOCUMENT REVIEW SHEET}

\begin{tabular}{|c|c|c|c|c|c|}
\hline \multicolumn{4}{|c|}{$\begin{array}{l}\text { 1. Document Title/Number Corrective Action Investigation Plan for CAU No. } 423 \text { : } \\
\text { Area 3, Building 03-60. Underground Discharge Point. Tonopah Test Range. } \\
\text { Nevada. }\end{array}$} & \multicolumn{2}{|l|}{ 2. Document Date July 1997} \\
\hline \multicolumn{4}{|c|}{ 3. Revision Number Draft } & \multicolumn{2}{|l|}{ 4. Originator/Organization IT Corporation } \\
\hline \multicolumn{4}{|c|}{ 5. Responsible DOE/NV ERP Subproject Mgr. Janet Appenzeller-Wing } & \multicolumn{2}{|l|}{ 6. Date Comments Due $8 / 09 / 97$} \\
\hline \multicolumn{6}{|c|}{ 7. Review Criteria } \\
\hline \multicolumn{6}{|c|}{ 8. Reviewer/Organization/Phone No. Bureau of Federal Facilities, NDEP } \\
\hline $\begin{array}{l}10 . \\
\text { Comment } \\
\text { Number/ } \\
\text { Location }\end{array}$ & $\begin{array}{l}11 . \\
\text { Type }\end{array}$ & Comment & 13. & Comment Response & $\begin{array}{c}14 . \\
\text { Accept }\end{array}$ \\
\hline $\begin{array}{l}\text { 1. Page } 9 \text { of } 37 \text {, } \\
\text { Paragraph } 1\end{array}$ & M & $\begin{array}{l}\text { In the first paragraph, the second sentence states only "a small } \\
\text { amount of residual sludge" was left in the UDP following } \\
\text { pumping. In the third sentence it is stated there was } 8.5 \text { inches } \\
\text { of liquid standing in the UDP over a year later. Where did the } \\
\text { liquid come from? What will be done with the liquid (listed } \\
\text { waste)? Is the facility in Building } 03-06 \text { still actively adding to } \\
\text { the UDP? Was the UDP sealed during the time interval from } \\
\text { pumping to the second measurement? Is the pipe from building } \\
03-60 \text { sealed? }\end{array}$ & $\begin{array}{l}\text { Text } \\
\text { Pote } \\
\text { thre } \\
\text { surf: } \\
\text { the } \\
\text { aboi } \\
\text { sece } \\
03-6 \\
\text { elim } \\
\text { third } \\
\text { soils } \\
\text { beer } \\
\text { with } \\
\text { rem }\end{array}$ & $\begin{array}{l}\text { as been added in Section } 2.5 \text { to reflect the following: } \\
\text { ial liquid input to the UDP is currently considered as a } \\
\text { ariable system. The first variable is the addition of } \\
\text { water (i.e., stom runoff) due to water standing on } \\
\text { orly sealed lid of the UDP. The top of the UDP is now } \\
\text { grade, eliminating further surface water input. The } \\
\text { d variable is the addition of liquid through the Building } \\
\text { discharge pipe. The discharge pipe is now capped, } \\
\text { ating further liquid input from the discharge line. The } \\
\text { ariable is possible infiltration of liquid from saturated } \\
\text { urrounding the UDP. A Stevens Depth Recorder has } \\
\text { nstalled to monitor any fluctuations of liquid level } \\
\text { the UDP. Liquid in the UDP is scheduled to be } \\
\text { ed and properly disposed of in October, } 1997 \text {. }\end{array}$ & Yes \\
\hline $\begin{array}{l}\text { 2. Page } 26 \text { of } \\
\text { 37. Paragraph } 3 \text {, } \\
\text { Sentence } 3\end{array}$ & M & $\begin{array}{l}\text { In the third paragraph, the third sentence indicates a fresh } \\
\text { media grab sample will be used for laboratory samples. This } \\
\text { statement is counter to the schematic in Figure } 4-2 \text {. Is a fresh } \\
\text { core to be drawn following screening? Is the fresh media simply } \\
\text { a fresh aliquot of the same core media? }\end{array}$ & $\begin{array}{l}\text { The } \\
\text { char }\end{array}$ & $\begin{array}{l}\text { xt on Page } 28 \text {, paragraph } 3 \text {, sentence } 3 \text { has been } \\
\text { ed so "grab samples" is replaced with aliquots. }\end{array}$ & Yes \\
\hline
\end{tabular}




\section{NEVADA ENVIRONMENTAL RESTORATION PROJECT \\ DOCUMENT REVIEW SHEET}

Document Titie/Number Corrective Action Investigation Plan for CAU No. 423:

Revision Number

Area 3, Building 03-60, Underground Discharge Point. Tonopah Test Range,

Nevada

Reviewer/Organization Dean Mierau, Bureau of Federal Facilities, NDEP

\begin{tabular}{|c|c|c|c|c|}
\hline $\begin{array}{l}10 . \\
\text { Comment } \\
\text { Number } \\
\text { Location }\end{array}$ & $\begin{array}{c}11 . \\
\text { Type }^{a}\end{array}$ & Comment & Comment Response & $\begin{array}{c}14 . \\
\text { Accept }\end{array}$ \\
\hline $\begin{array}{c}\text { 3. Appendix } A_{1} \\
\text { Page A-31 of } \\
\text { A-33 }\end{array}$ & M & $\begin{array}{l}\text { In the Appendix, the last paragraph is a statement regarding } \\
\text { storage and disposal. The statement concerns the liquid } \\
\text { pumped from the UDP (approximately } 400 \text { gallons). The } \\
\text { statement is part of an enclosure: Records for Hazardous Waste } \\
\text { dentification of Building 0360 Waste Oi! Underground Discharge } \\
\text { Point, which was included in a letter dated July 2, } 1996 \text { from } \\
\text { Richard A. Dubiskas and Cindy L. Dutro to Kevin Cabble. The } \\
\text { letter indicates (on Page A-29 of A-33) that Karen Beckley of } \\
\text { NDEP/CC should receive a copy of this letter for review. Karen } \\
\text { has not received a copy of this letter, nor the information } \\
\text { involved. It has not come to the attention of NDEP until this } \\
\text { report was received July } 11,1997 \text {. What has happened to the } \\
\text { liquid from the UDP ( } 400 \text { gallons) in the interim? Where is the } \\
\text { notificalion to NDEP? How was the listed waste disposed?, and } \\
\text { where?, and when? }\end{array}$ & $\begin{array}{l}\text { Attachment } 4 \text { has been modified and Attachment } 5 \text { has been } \\
\text { added to support the following: } \\
\text { Correspondence between D.S. Shafer and P.J. Liebendorfer } \\
\text { regarding the completion of a tecord search for hazardous } \\
\text { waste identification for the UDP has been added to } \\
\text { Attachment } 4 \text {. } \\
\text { The uniform hazardous waste manifests associated with the } \\
\text { CAU } 4239 / 04 / 95 \text { waste disposal are provided in } \\
\text { Attachment } 5 \text {. Approximately } 400 \text { gallons of liquid waste } \\
\text { removed from the UDP and investigation derived waste } \\
\text { produced by exposing, sampling, and pumping the UDP was } \\
\text { received by the transporter Laidlaw Environimental Services } \\
\text { of California. The designated facility for the waste was } \\
\text { Laidlaw Environmental Services SW. (Phoenix, AZ). }\end{array}$ & Yes \\
\hline
\end{tabular}

${ }^{a}$ Comment Types: $M=$ Mandatory, $S=$ Suggested.

Return Document Review Sheets to DOE/NV Environmental Restoration Division, Attn: QAC M/S 505 


\section{Distribution List}

\section{$\underline{\text { Copies }}$}

Paul J. Liebendorfer

2 (Controlled)

State of Nevada

Bureau of Federal Facilities

Division of Environmental Protection

333 W. Nye Lane, Room 138

Carson City, NV 89706-0851

Supervisor

Bureau of Federal Facilities

1 (Controlled)

Division of Environmental Protection

555 E. Washington, Suite 4300

Las Vegas, NV 89101

Sabrina D. Bonnell

Environmental Restoration Division

DOE/Nevada Operations Office

P.O. Box 98518, M/S 505

Las Vegas, NV 89193-8518

Dave Madsen

1 (Uncontrolled)

Bechtel Nevada

P.O. Box 98521, M/S NTS306

Las Vegas, NV 89193-8521

Steve Nacht

Bechtel Nevada

1 (Controlled)

P.O. Box 98521, M/S NTS306

Las Vegas, NV 89193-8521

Janet Appenzeller-Wing

1 (Uncontrolled)

Environmental Restoration Division

1 (Uncontrolled)

DOE/Nevada Operations Office

P.O. Box 98518, M/S 505

Las Vegas, NV 89193-8518

Kevin J. Cabble

1 (Uncontrolled)

Environmental Restoration Division

DOE/Nevada Operations Office

P.O. Box 98518, M/S 505

Las Vegas, NV 89193-8518 
Ken Beach

IT Corporation

P.O. Box 93838

Las Vegas, NV 89193

Mary Todd

IT Corporation

P.O. Box 93838

Las Vegas, NV 89193

Mark DiStefano

IT Corporation

P.O. Box 93838

Las Vegas, NV 89193

Jason Moore

IT Corporation

P.O. Box 93838

Las Vegas, NV 89193

IT Corporation Central Files

IT Corporation

P.O. Box 93838

Las Vegas, NV 89193
1 (Uncontrolled)

1 (Uncontrolled)

1 (Uncontrolled)

1 (Uncontrolled)

1 (Uncontrolled) 